\title{
Cardiac remodeling and angiotensin II after an experimental myocardial infarction
}

Citation for published version (APA):

van Krimpen, C. (1991). Cardiac remodeling and angiotensin II after an experimental myocardial infarction. [Doctoral Thesis, Maastricht University]. Rijksuniversiteit Limburg. https://doi.org/10.26481/dis.19910620ck

Document status and date:

Published: 01/01/1991

DOI:

10.26481/dis.19910620ck

Document Version:

Publisher's PDF, also known as Version of record

\section{Please check the document version of this publication:}

- A submitted manuscript is the version of the article upon submission and before peer-review. There can be important differences between the submitted version and the official published version of record.

People interested in the research are advised to contact the author for the final version of the publication, or visit the DOI to the publisher's website.

- The final author version and the galley proof are versions of the publication after peer review.

- The final published version features the final layout of the paper including the volume, issue and page numbers.

Link to publication

\footnotetext{
General rights rights.

- You may freely distribute the URL identifying the publication in the public portal. please follow below link for the End User Agreement:

www.umlib.nl/taverne-license

Take down policy

If you believe that this document breaches copyright please contact us at:

repository@maastrichtuniversity.nl

providing details and we will investigate your claim.
}

Copyright and moral rights for the publications made accessible in the public portal are retained by the authors and/or other copyright owners and it is a condition of accessing publications that users recognise and abide by the legal requirements associated with these

- Users may download and print one copy of any publication from the public portal for the purpose of private study or research.

- You may not further distribute the material or use it for any profit-making activity or commercial gain

If the publication is distributed under the terms of Article $25 \mathrm{fa}$ of the Dutch Copyright Act, indicated by the "Taverne" license above, 
CARDIAC REMODELING AND ANGIOTENSIN II AFTER AN EXPERIMENTAL MYOCARDIAL INFARCTION 
CARDIAC REMODELING AND ANGIOTENSIN II

AFTER AN EXPERIMENTAL MYOCARDIAL INFARCTION

\section{PROEFSCHRIFT}

ter verkrijging van de graad van doctor aan de Rijksuniversiteit Limburg te Maastricht, op gezag van de Rector Magnificus, prof. $\mathrm{mr}$. M.J. Cohen, volgens het besluit van het College van Dekanen, in het openbaar te verdedigen op donderdag 20 juni 1991 om 14.00 uur.

door

Cornelis van Krimpen

geboren te Vlaardingen 


\title{
Promotores
}

Prot.dr. F.T. Bosman

Prof.dr. H.A.J. Struyker Boudier

Co-promotores

Dr. M.J.A.P. Daemen

Dr. J.F.M. Smits

Beoordelingscommissie

Prof.dr. M.A. Allessie, voorzitter

Dr. F. Bär

Prof.dr. F.C.S. Ramaekers

Prof.dr. J.J. Weening, Rijksuniversiteit Groningen

Prof.dr. P.A. van Zwieten, Universiteit van Amsterdam

\section{CIP-DATA KONINKLIJKE BIBLIOTHEEK, DEN HAAG}

\author{
Krimpen "Comelis van
}

Cardlac rernodeling and angiotensin If after an experimental myocardial infarction / Cornelis van Krimpen. [S.l: : s.n.]

Thesis Maastricht. - With ref. - With summary in Dutch.

ISBN 90-9004167-2

Subject headings: cadiac remodeling / angiotensin II / myocardial infarction.

Druk: ICG printing BV, Dordrecht 1991

Foto's: Audiovisuele dienst Academisch Ziekenhuis Maastricht

The work described in this thesis was performed as a collaborative research project of the Department of Pathology. University of Limburg (Prof.dr. F.T. Bosman) and the Department of Pharmacology. University of Limburg (Prof.dr. H.A.J. Struyker Boudier). This project was financially supported by the Netherlands Heart Foundation, grant 88.224.

Financial support for the publication of this thesis was given by:

- Becton Dickinson Image Cytometry Systems, The Netherlands

- Bristol-Myers Squibb, The Netherlands

- Department of Pharmacology, State University of Limburg

- ICl-Farma, The Netherlands

- Stichting Bevordering Klinische Pathologie Limburg

- Stichting Samenwerkende Delftse Ziekenhuizen

- The Netherlands Heart Foundation

Their help is gratefully acknowledged. 
Who hath put wisdom in the inward parts? or who hath given understanding to the heart?

(Job 38:36, King James Version) 


\section{LIST OF ABBREVIATIONS}

ACE Angiotensin I converting enzyme

All Angiotensin II

ICL Inner circumference of the left ventricle

ICA Inner circumference of the right ventricle

HWI Heart weight index; heart weight corrected for body weight

LAC Left ventricular wall area corrected for infarct size

LAIC Left ventricular wall area corrected for infarct size and body weight

MI Myocardial infarction

RA Right ventricular wall area

SHAM Sham operated animals

SR $\quad$ Sirius Red

DuP 753 2-n-butyl-4-chloro-5-hydroxy-methyl-1-[2'-(1H-tetrazol-5-yl) biphenyl-4-yl)methyl] imidazole potassium salt 


\section{TABLE OF CONTENTS}

1. INTRODUCTION

1.1 General 11

i.2 Compensatory mechanisms

1.2.1 Peripheral compensatory mechamisms

1.2. Cardiac compensatory mechanisms

1.2 .3 Factors initiating cardiac remodeling 15

1.2.4 Proto-oncogenes and cardiac remodeling 20

$\begin{array}{lll}1.3 & \text { Thesapy } & 21\end{array}$

$\begin{array}{llr}1.4 & \text { Aim of the studies } & 24\end{array}$

1.4. Questions addressed to this study 25

$\begin{array}{ll}\text { References } & 26\end{array}$

2. MATERIALS AND METHODS

2.1. Animals 34.

2.2 Surgery

2.3 In vivo labeling of DNA synthesizing Colis 34

2.4 Tissue processing 35

2.5 Immunohistochemistry 35

2.6 Determination of the fraction of Brdlul labeled nuclei 36

2.7 Morphometry to determine ventricular and cardiomyocyte dimensions 37

2.8 Collagen staining 39

2.9 Morphometry to determine the collagen positive area 40

2.10 Data analysis $\quad 40$

2.11 Drugs used in this thesis

References $\quad 43$

3. STRUCTURAL ALTERATIONS IN THE RAT HEART

AFTER MYOCARDIAL INFARCTION

3.1 Introduction $\quad 46$

32 Expermental protocols 47

3.2. 1 Morphometry and quantitation of collagen content 47

3.2 .2 In viwo labeling of DNA symthesizing cells

3.3 Results 48

3.3.1 Infarct size, body weight and heart weight 48

3.3.2 Left and right ventricular wall area 48

3.3.3 Left and right ventricular inner circumference $\quad 50$

3.3.4 Left and right ventricular cardiomyocyte volume 51

3.3.5 Left and right ventricular DNA synthesis 52

336 Left and right ventricular collagen content

3.4 Discusion 34

$\begin{array}{lr}\text { Rieferences } & 57\end{array}$

4. EFFECTS OF EARLY AND DELAYED CAPTOPRIL. TREATMENT ON STRUCTURAL ALTERATHONS IN THE RAT HEART AFTER MYOCARDIAL INFARCTION

4. II Introctuction 60

4.2 Experimental prolocols 61

4.2. Animals $\quad 61$

4.2.2 Treatment $\quad 61$

4.3 Piesulls $\quad 62$

4.3.1 Intarct size

4.3.2 Etiects on heart weight index

4.3.3 Ettects on left ventricular wall arba $\quad 63$

4.3.4. Effects on left ventricular inner circumflerence

4.3 .5 Effects an left ventricular cardiomyocyte volume

4.4 Discussion

Rieferences $\quad 70$ 
5. EFFETS OF EAALV AND DELAYED CAPTOPRIL TREATMENT

ON WYOCARDLAL DNA SWNTHESHS AND COLLAGEN CONTENT

AFTER AN EXPEFIMENTAL MYOCARDIAL INFARCTION

5.1 Introduction

5.2 Experimemal protocols:

5.2. Captopril treatment

5.2.2 Hydralazine treatment

5.3 Results

5.3. I Infarct size

5.32 Effects of early treatment on left and right ventricular DNA synthesis

5.3.3 Effects of early and deleyed treatment on left and right ventricular collagen contert

54 Digcussion

Feferences

6. EFFECTS OF EARLY TREATMENT WITH THE ANGIOTENSIN II-1 RECEPTOR ANTAGONIST DUP753 ON THE STRUCTURAL ALTERATIONS IN THE RAT HEART AFTEF MYOCARDIAL INFARCTION

6.4 Introduction

6.2 Experilriental protocols

6.2.1 Animalis

6.2.2 Treatmeint

63 Results

6.3.1 Effects on left ventricular wall area and inner circumference

6.3.2 Effects on left ventricular cardiomyocyte volume

6.3.3 Effects on left ventricular interstitial DNA synthesis

6.3.4 Etfects on left ventricular collagen content

6.4 Discussion

References

7.2 Cardiac remodeling and myocardial infarction

7.2 .1 Ventricular dilatation

7.2 .2 Cardiomyocyte hypertrophy

7.2 .3 Myacardial D|NA synthesis

7.2.4 Myocarclal interstitial collagen synthesis

7.2 .5 Myocardial capillary density

7.3 Cardiac remodeling after myocardial intarcton and angiotensin II

7.3.1 introduction, drug treatment

7.3.2 Ventricular dilatation and angiotensin II!

7.3.3 Cardiomyocyte hypertrophy and angiotensin $\|$

7.3.4 Myacardial tibroblast proliferation and anciotensin II

7.3.5 Myocardial interstitial collagen symhesis and anglotensin lil

7.4 Future prospects

feferences 
CHAPTER 1

\section{INTRODUCTION}

No organ in the body is so conservative as the heart;" what improvement it has obtained in the course of its history it never loses;

its progress is made not only by the introduction of new structures but by modification of the old.

Sir Arthur Keith (1904) 



\subsection{GENERAL}

schemic heart disease may present as angina pectoris, acute myocardial infarction, or sudden death. In the mid 1980 's, acute myocardial infarction (MI) killed about 35.000 people every year in the Netherlands (Grobbee and Hofman, 1989).

Myocardial infarction can reduce cardiac output. The reduced cardiac output activates both peripheral and cardiac compensatory mechanisms. These mechanisms initially compensate the impaired cardiac function (Meerson, 1983), but can eventually result in a further attenuation of cardiac function (Katz, 1990a), leading to congestive heart failure. Congestive heart failure, defined as the pathophysiological state in which the cardiac output is insufficient to meet the metabolic needs of the body (Braunwald, 1988; Ruggie, 1986), is associated with circulatory congestion. Symptoms of congestive heart failure are pulmonary edema, dyspnea and peripheral edema. Once congestive heart failure is a fact, exercise capacity is low (Poole-Wilson et al, 1988) prognosis is poor. Therapy usually is too much focussed on the above described symptoms. Although many new therapeutic agents have been developed which reduce symptoms, overall mortality remains still high, approximately $50 \%$ within the first year.

\subsection{COMPENSATORY MECHANISMS}

As described above, the reduced cardiac output after MI activates both peripheral and cardiac compensatory mechanisms. The most important of these, as well as their interrelationships, are depicted in figure 1. 


\subsubsection{Peripheral compensatory mechanisms}

First of all, sympathetic activation may result from an interplay between cardiopulmonary and sino-aortic baroreflex activation. The former depends upon increased cardiac filling pressures, whereas the latter may be activated as a consequence of reduced cardiac output (Carlton and Beartschi, 1982). The net result is an increase in sympathetic nervous activity, and hence, arteriolar vasoconstriction (Remme, 1986; Drexler et al, 1989). Secondly, if cardiac output remains depressed, endocrine systems become activated. One of these is the renin-angiotensin-aldosterone system. Angiotensin $\|$ is a potent vasoconstrictor and contributes to the increased systemic vascular resistance. It also facilitates noradrenaline release from sympathetic nerve endings. Finally, it causes water and salt retention, not only by a direct effect on tubular epithelium, but also through release of aldosterone which further promotes retention of salt and water (Francis, 1985; Laragh, 1986). Also the release of other hormones, like vasopressin and atrial natriuretic peptide, contributes to regulation of vascular tone and water and salt homeostasis (Remme, 1986; Genest, 1986; Morris et al, 1987; De Vries et al, 1990). The net effect is an increased peripheral resistance and volume expansion.

As a result, these attempts to maintain perfusion pressure increase ventricular pre-and afterload and reduce the already impaired ventricular function. The increase in preload adds to the congestion of the circulation (Francis et al, 1984). A vicious circle ensues. 


\subsubsection{Cardiac compensatory mechanisms}

Myocardial infarction results in a scar (Gravanis, 1987). Throughout the healing process the infarcted wall gradually thins as resorption of necrotic tissue progresses (Fishbein et al, 1978). Fibroblast proliferation and collagen deposition leads to scar formation. This scar tissue induces elevated wall tension in the remaining myocardium and may lead to disruption of the normal temporal sequence of ventricular contraction, which has been referred to as asynchrony (Herman et al, 1967). Also, a large myocardial infarction can lead to the development of an aneurysm due to expansion of the fibrous scar (Hochman and Bulkley, 1982). This creates an area of paradoxical systolic expansion of a portion of the ventricular wall, deforming the ventricular cavity. When akinetic areas approach 20 to 25 percent of the myocardium, in spite of increased wall tension development and muscle shortening in the non-infarcted myocardium an adequate stroke volume can no longer be maintained (Gravanis, 1987; Pfeffer and Braunwald, 1990).

It has become increasingly clear that particularly large transmural myocardial infarcts not only result in alterations in the infarcted area but also in the non-infarcted area. These include biochemical, electrophysiological and structural alterations. For instance, a shift in cardiac myosins towards a slower contracting type of fibers associated with a lower oxygen consumption, a lower ATP-ase activity and a decreased calcium sensitivity, has been reported (Gorza et al, 1984; Morano et al, 1988; Bouvagnet et al, 1989). Impaired $\mathrm{Ca}^{2+}$ re-uptake in sarcoplasmatic reticulum (Ito et al, 1974; Katz, 1989), adds to the impairment of contraction and relaxation (Meerson, 1983). 
The structural alterations are often referred to as "ventricular remodeling". The left veritricle is dilated (Pfeffer and Braunwald, 1990) and shows an enlarged cavity, in an attempt to restore stroke volume, but at the same time diminishing ejection fraction. Left ventricular dilatation is associated with side-to-side slippage of cardiomyocytes (Olivettil et al, 1990). Without concomitant wall thickening, these responses may initially preserve relaxation (Raya et al, 1988) and filling.

Another type of structural change, which occurs in parallel to dilatation, is cardiomyocyte hypertrophy, In rats, following large myocardial infarction, cardiomyocyte volume increases by up to $78 \%$ (Anversa et al, 1985).

With respect to the extracellular matrix, an increase of interstitial collagen, reflecting interstitial fibrosis, is observed (Michel et al, 1988). Although this phenomenon has been scarcely studied in myocardial infarction, another model of pressure overload, i.e. hypertension, has been widely used to study collagen turnover in the myocardium. Not only is there an increased deposition, but there is also a change in type of collagen (Chapman et al, 1990). The significance of this increased myocardial collagen content and its relation to the function of the left ventricle remain unclear (Weber et al, 1987). A rapid increase in collagen synthesis may help to maintain mechanical efficiency by reducing dilatation and wall tension (Katz, 1990a). Although this initial response is likely to be adaptive (Benjamin et al, 1989), subsequent changes in the myocardial extracellular matrix may contribute to the impaired relaxation which is observed in patients with heart failure (Katz, 1990a). The increased collagen content can also affect local conduction within the heart. 
Accumulation of collagen, particularly in the sub-endocardium, could impair the progression of the depolarization wave over the myocardium and thus facilitate reentrant activity and arrhythmias (Merx et al ${ }^{2} 1977$ ).

In parallel with these phenomena a decrease of the capillary density of the non-infarcted myocardium has been described (Meerson. 1983), which results in an increased maximal oxygen diffusion distance (Anversa et al, 1986).

\subsubsection{Factors initiating cardiac remodeling}

Several factors may be involved in the initiation of the remodeling of the myocardium after MI. These include 1) an increased wall stress due to volume and/or pressure overload, 2) activation of the sympathetic nervous system and 3) activation of the renin-angiotensin system. The latter two are also (partially) responsible for the above mentioned phenomena of peripheral compensation (FIG. 1). This adds to the complexity of peripheral and cardiac compensatory mechanisms, since peripheral compensatory mechanisms, including activation of the sympathetic nervous system and the renin-angiotensin system, may also facilitate the development of cardiac failure. 


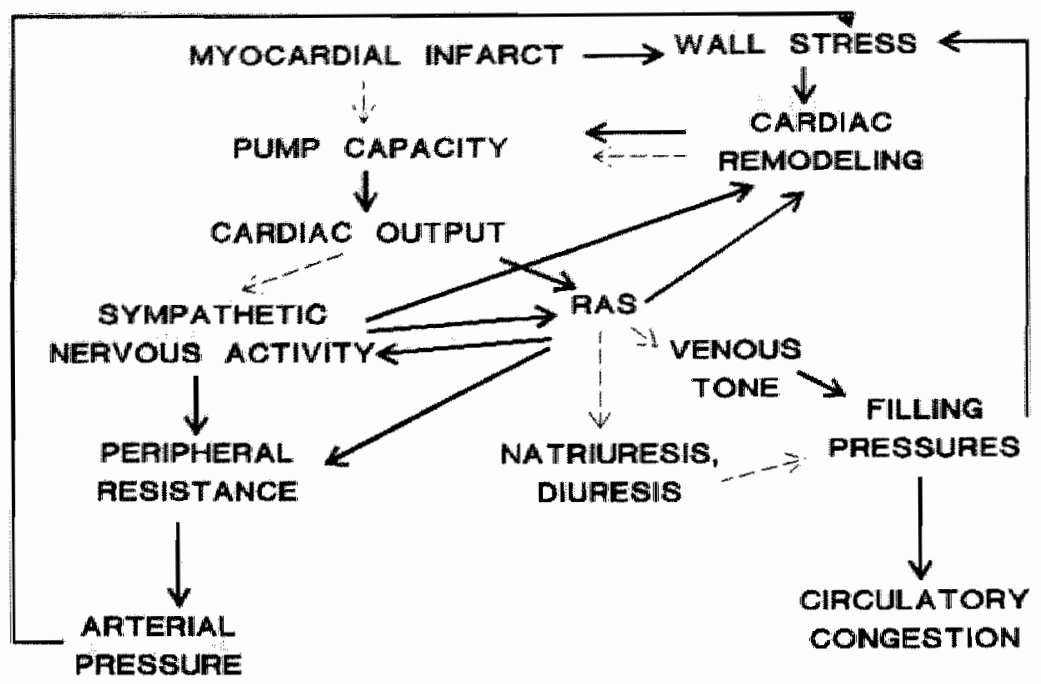

FIG. 1; Interrelations between peripheral and cardiac compensatory mechanisms, after a myocardial iniarcion.

-nom $>$ : Positive effects

$\ldots>$ : Negative effects

\section{1) Wall stress}

Increased preload and afterload may, as such, represent triggers for cardiac remodeling. In this respect, recent studies on isolated strips of feline myocardium provided data which suggest that load variation of cardiomyocytes might function as an independent regulator of cardiomyocyte hypertrophy (Cooper IV et al, 1989). 
Explaning this effect, these authors hypothesized that sarcolemmal deformation may activate stretch-sensitive ion-channels. The resultant increase in $\mathrm{Na}^{*} / \mathrm{Ca}^{2+}$ exchange increases intracellular sodium, and thereby constitutes a primary step for increased protein synthesis (Cooper $W$ et all, 1989). This phenomenon might link load and cardiomyocyte growth in the heart. The effects of ventricular overload on chamber dilatation associated with increased wall stress have been clescribed above.

\section{2) Sympathetic nervous system}

Sympathetic activation may result from sino-aortic baroreflex activation as a consequence of reduced cardiac output. Alternatively, activation of primary cardiac sympathetic afferents has been put forward to explain the increase in sympathetic nerve activity (Peres et al, 1987). The myocardium contains $\alpha$ and $\beta$-adrenoceptors. Results from in vitro studies suggest that stimulation of $\alpha 1$ (and not $\beta$ ) -adrenergic receptors induces neonatal cardiomyocyte hypertrophy (Simpson, 1985; Simpson, 1989; Long et al, 1990). It has also been shown that cardiomyocyte hypertrophy, induced by $\alpha 1$-adrenergic agonists, leads to increased c-myc mRNA (Starksen et al, 1986). In addition cardiac hypertrophy has been shown to occur in c-myc transgenic mice (Robbins and Swain, 1989). In adult rat cardiomyocytes, $\beta$ adrenoceptor stimulation has been suggested to modulate hypertrophy (Schwartz,

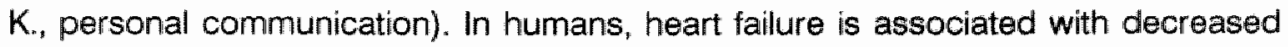
numbers of B-adrenergic receptors (Bristow et al, 1986). In this respect, the response in the rat heart following myocardial infarction seems to be different, because in that model, no change in $\beta$-adrenoceptor number, nor affinity 
to antagonists was reported (Clozel et al, 1987).

It is assumed that activation of the sympathetic nervous system also leads to the synthesis of collagens in the myocardial interstitium. Supportive evidence is provided by experiments which show that $B$-adrenergic receptor agonists (e.g. isoprenaline) induce subendocardial fibrosis (Jalil et al, 1989). However, neither is the mechanism understood in detail, nor is exactly known which cell types are involved in the deposition of myocardial extracellular matrix after MI.

\section{3) Renin-angiotensin system}

The elaboration of angiotensin $\|$ (AII) is the result of conversion of the inactive peptide angiotensin I by the angiotensin I converting enzyme (ACE). All is a potent vasoconstrictor and facilitates noradrenergic transmission in the sympathetic nervous system and thus further augments $\alpha$-adrenoceptor-mediated vasoconstriction (Gravanis, 1987).

Recently, components of the renin-angiotensin system have also been demonstrated in various tissues and organs, including the heart (Campbell, 1987; Re, 1987; Dzau, 1987). In the hypertrophied rat heart after aortic banding increased expression of angiotensinogen and ACE mRNA has recently been described (Baker et al, 1990; Schunkert et al, 1990). Although also renin mRNA expression has been reported in the myocardium ( $R e, 1987$ ), there is no information with respect to its regulation.

Angiotensin II receptors have been subject of recent studies. Two receptor subtypes have been characterized in the rat adrenal gland and have been named All-1 and All-2 receptors (Chiu et al, 1989). 
Both receptors have also been identified in rabbit cardiac membrane preparations (Rogg et al, 1990). With respect to involvement of All receptors in the hypertrophic response, it is interesting to note that the mas-oncogene product has been put forward as an angiotensin $\|$ receptor (Jackson et al, 1988). This remains, however controversial (Brown, 1989). Angiotensin II has been reported to stimulate protein synthesis in chick cardiomyocytes (Aceto and Baker, 1990).

Besides membrane receptors, also receptors located in the cardiomyocyte nucleus have been described ( $R$ e, 1987). Although the characteristics of the binding-site are not known, it has been suggested that these intracellular All receptors are involved in myocardial DNA synthesis, which might indicate that angiotensin II itself is a growth factor for myocardial cells (Katz, 1990b).

Thus, in addition to its effects on pre- and afterload, All might be directly involved in regulation of growth and differentiation of cardiac and vascular smooth muscle cells (Dzau, 1987; Re, 1987; Daemen et al, 1991; Schelling et al, 1991). The reninangiotensin system may also be involved in the regulation of the interstitial response to myocardial infarction. Angiotensin II has been shown to induce DNA synthesis in $3 T 3$ fibroblasts (Schelling et al, 1979). It is also involved in the regulation of remodeling of the interstitial compartment of the myocardium in pressure overload hypertrophy (Weber et al, 1988, 1989). It has been suggested that All enhances endothelial permeability in small coronary arteries (Bhan et al, 1978; Giacomelli et al, 1976). In this way, putative mitogens (e.g. PDGF) could gain access to the myocardial interstitium (Weber, 1989) and induce interstitial cell proliferation and subsequent collagen synthesis. The role of All as a possible growth factor in vivo, however, is not yet clearly understood. 


\subsubsection{Proto-oncogenes and cardiac remodeling}

The proto-oncogenes exert their regulatory effects by encoding a variety of growth factors and their receptors, intracellular transducers, modulators, amplifiers, and DNA-binding factors involved in the control of RNA transcription (Katz, 1990). The major part of our knowledge of induction of proto-oncogene expression in the myocardium is derived from pressure overload induced hypertrophy in small animals. It is apparent that hemodynamic overloading increases the expression of $c$-fos and c-myc (amongst athers), proto-oncogenes that encode nuclear proteins which promote and regulate cell proliferation and differentiation. The induction of cfos and e-myc, which occurs within an hour of acute pressure overload, is transient and precedes the re-expression of fetal isoforms of several contractile proteins (skeletal muscle type $a$-actin and sarcomeric tropomyosin) and atrial natriuretic factor (Izumo et al, 1988). Additionally, in the overloaded heart, the activation of cfos and c-myc goes along with activation of the heat shock protein gene HSP 70 . The heat shock or stress proteins are possibly involved in protecting the viability of cells under adverse conditions (like acute hemodynamic overload) and might affect proper protein folding and/or modulation of gene transcription (Nadal-Ginard and Mahdavi, 1989). Expression of these proto-oncogenes may occur in cardiomyocytes as well as myocardial connective tissue cells. Although the biological significance is not clear, this might indicate an early mitogenic response to growth factors by myocardial cells. Because a continuous hemodynamic overload is necessary for the development of hypertrophy, expression of these genes by itself may not be sufficient to trigger the hypertrophic response, but they may play a permissive role in mediating this response. 
Although rapid progress in this field promises new insights into the pathogenesis of the cardiomyopathy of overload, the roles of proto-oncogenes in activation and reprogramming of gene expression in the overloaded heart remain to be fully elucidated.

\subsection{THERAPY}

Our studies are focussed on myocardial infarction, one of the main causes of heart failure. For the treatment of heart failure a choice can be made from four main groups of drugs:

-Positive inotropic agents, divided into cardiac glycosides, sympathicomimetics and phosphodiesterase inhibitors (with and without Ca-sensitizing activity). The major action of these agents is to increase myocardial contractility. Positive inotropes can acutely improve the function of the heart and the condition of the patient (Lejemtel et al, 1984; Colluci et al, 1986a,b; Farah, 1986; Braunwald, 1986; Wetzel et al, 1988). However, they increase the myocardial energy demand (Katz, 1986) and have arrhythmogenic effects (Parmley et al, 1986; Colluci et al, 1986a, b; Katz, 1986). Furthermore, their administration does not result in increased survival (Packer et al, 1987; Cohn, 1989; DiBianco et al, 1989). Their effects on cardiac remodeling after $\mathrm{MI}_{\sharp}$ are not known in detail.

-Diuretic agents, like hydrochlorthiazide and furosemide, are primarily used to relieve the patient from symptoms of systemic or pulmonary congestion. Diuretics decrease the circulating volume and reduce cardiac filling and output. Consequently, renal flow and glomerular filtration rate are decreased (Nelson et all, 1984), which results in stimulation of the renin-angiotensin-aldosterone system. 
This leads to increased vascular resistance (Remme, 1986; Bayliss et al, 1987). which limits the value of these agents for long term therapy.

-Vasodilators are used to unload the heart without direct action on ventricular contractility. Different groups of agents can be distinguished, based on their mechanism of action: direct vasodilators, such as nitrates and hydralazine, alpha-1 adrenoceptor blockers, centrally acting sympatholytics, $\mathrm{Ca}^{2+}$-channel blockers and angiotensin I converting enzyme inhibitors, such as captopril and enalapril (Levine, 1985). The latter group of drugs will be discussed separately.

Hydralazine has predominantly arteriolar vasodilating effects. Nitrates, such as isosorbide dinitrate, have venodilating effects. Despite short-term favorable effects, selective arteriolar dilatation may further increase preload due to fluid retention as a result of a decreased renal function (decreased glomerular filtration rate) caused by a lower blood pressure. The effects of selective vasodilating agents are counterregulated by neurohumoral reflex mechanisms, such as activation of the sympathetic nervous system and the renin-angiotensin system (Leenen et al, 1987). As a result, hydralazine does not reduce ventricular hypertrophy in hypertensive patients (Leenen et al, 1987). Selective venodilatation may reduce cardiac filling, needed to preserve cardiac output after MI. Combined therapy with hydralazine and isosorbide dinitrate (Cohn et al, 1986) has been found to reduce mortality, suggesting that a balanced venous and arterial dilatation is an effective mode of treatment of heart failure. 


\section{-Angiotensin I converting enzyme inhibitors}

Although these agents have originally been classified as vasodilators, their specific actions warrant a separate classification. Hemodynamically, they have balanced venous and arteriolar dilating effects (Levine, 1985; Packer, 1986; Chatterjee et al, 1988). Large scale studies in heart failure patients with enalapril (Consensus Trial, 1987) and in rats with enalapril (Sweet et al, 1987) and captopril (Pfeffer et al, 1985a) showed that chronic converting enzyme inhibitor therapy increases survival. Captopril therapy attenuated ventricular dilatation in rats (Pfeffer et al, 1985b) and humans (Pfeffer et al, 1988; Pfeffer and Braunwald, 1990) after MI. The attenuation of ventricular dilatation by captopril therapy might be associated with the reduction in mortality, since ventricular enlargement increases ventricular wall stress and seems to be highly correlated with a bad prognosis (Pfeffer and Braunwald, 1990). Furthermore, recent studies by Michel et al (1988) have shown that sustained ACE inhibition, started in the second week after infarct induction also reduces left and right ventricular collagen content of the rat heart. These observations suggest that inhibition of the activated renin-angiotensin system interferes with the cardiac remodeling processes. 


\subsection{AIM OF THE STUDIES}

Prognosis of patients treated with converting enzyme inhibitors, remains still poor, once congestive heart failure is diagnosed. Therefore it has been suggested to start therapy after MI even before overt symptoms of congestive heart failure occur (Gorlin; 1987; Sharpe, 1989). However, the effects of this type of treatment on the alterations in the myocardial structure after Ml are not yet known.

Furthermore Schoemaker et al (1991) showed that angiotensin I converting enzyme inhibition with captopril, during the healing phase of $\mathrm{Ml}$ in rats, does not augment but rather attenuates cardiac function. Thus, timing of the start of ACE inhibition in relation to the onset of the infarction seems to be essential (Katz, 1990b).

These observations suggest that the initial myocardial remodeling following $\mathrm{MI}$ is beneficial and necessary to maintain cardiac function. Early therapy with ACE inhibitors should therefore not interfere with this essential phase in the process of recovery. Early ACE inhibition might, however, interfere with the beneficial early structural alterations, while delayed treatment might not have this effect. Early or delayed therapy may therefore have different effects on ventricular remodeling. Consequently, exact timing of chronic angiotensin I converting enzyme inhibition is important to avoid unfavorable effects of therapy. 


\subsubsection{Questions addressed in this study}

1) Which structural alterations occur in the rat heart after induction of a myocardial infarction? Which changes occur in ventricular wall dimensions, cardiomyocyte volume and myacardial interstitium? Are DNA synthesis and collagen dleposition enhanced after myocardial infarction? (chapter 3)

2) What are the effects of early and delayed angiotensin I converting enzyme inhibition by captopril on the MI induced alterations in ventricular wall dimensions and cardiomyocyte volume? (chapter 4)

3) What are the effects of early and delayed angiotensin I converting enzyme inhibition by captopril on the Ml induced alterations in the myocardial DNA synthesis and collagen content? (chapter 5)

4) What are the effects of angiotensin II receptor blockade on the early changes in left ventricular wall dimensions, cardiomyocyte volume, DNA synthesis and collagen content? (chapter 6) 


\section{REFERENCES}

Aceto, J.F., Baker, K.M., [Sar']angiotensin II receptor-mediated stimulation of protein synthesis in chick heart cells. Am J Physial 258, H806-H813 (1990).

Anversa, P., Loud, A.V., Levicky, V., Guideri, G. Left ventricular fallure induced by myocardial infarction. I. Myocyte hypertrophy. Am J Physiol 248, H876-882 (1985).

Anversa, P., Beghi, C., Kikkawa, Y., Olivetti, G. Myocardial infarction in rats. Infarct size, myocyte hypertrophy, and capillary growth. Circ Res 58, 26-37 (1986).

Baker, K.M., Chernin, M.l., Wixon, S.K., Aceto, J.F. Renin-angiotensin system imvolvement in pressure-overload cardiac hypertrophy in rats. Am J Physiol 259, H324-H332 (1990).

Bayliss, J., Norell, M., Canape-Anson, R., Sutton, G., Poole-Wilson, P. Untreated heart failure: clinical and neuroendocrine effects of introducing diuretics. $\mathrm{Br}$ Heart $\mathrm{J}$ $57,17-22$ (1987).

Benjamin, I.J., Jalil, J.E., Tan, L.B., Cho, K., Weber, K.T., Clark, W.A. Isoproterenolinduced myocardial fibrosis in relation to myocyte necrosis. Circ Res 65, 657-670 (1989).

Bhan, R.D., Giacomelli, F., Wiener, J. Ultrastructure of coronary arteries and myocardium in experimental hypertension. Exp Mol Path 29, 66-81 (1978).

Bouvagnet, P., Mairhofer, H. Leger, J.O.C., Puech, P., Leger, J.J. Distribution pattern of alpha- and beta-myosin in normal and diseased human ventricular myocardium. Basic Res Cardiol 84, 91-102 (1989).

Braunwald, E. Newer positive inotropic agents. Circulation 73(suppl 3), 237-239 (1986).

Braunwald, E. Pathophysiology of heart failure. In: Braunwald, E. ed. Heart disease, a textbook of cardiovascular medicine. Philadelphia: W.B. Saunders, 426-448 (1988).

Bristow M.F., Ginsburg, R., Umans, V.. Fowler, M., Minobe, W., Rasmussen, R., Zera, P., Meniove, R., Shah, P., Jamieson, S., Stinson, E.B. Beta-1 and beta-2 adrenergic receptor subpopulations in non-failing and failing human ventricular myocardium: coupling of both receptor subtypes to muscle contraction and selective beta-1 receptor down regulation in heart failure. Circ Res 59, 297-309 (1986).

Brown, K. Angiotensin receptors are implicated in the mechanism of mas action. Trends Pharmac Sci 10, 87-89 (1989). 
Campbell, D.J. Circulating and tissue angiotensin systems, J Clin Invest $79, \quad 1-6$ (1987).

Carlton, J.D., Beartschi, A.J. Responses of aortic baroreceptors to changes of aortic blood flow and pressure in rat. Am J Physiol 242, H520-H525 (1982).

Chapman, D., Weber, K.T., Eghbali, M: Regulation of fibrillar collagen types I and III and basement membrane type IV collagen gene expression in pressure overloaded rat myocardium. Circ Res 67, 787-794 (1990).

Chatterjee, K. DeMarco, T., Rouleau, J-L. Vasodilator therapy in chronic congestive heart failure. Am J Cardiol 62, 46A-54A (1988).

Chiu, A.T., Herblin, W.F., McCall, D.E., Ardecky, R.J., Carini, D.J., Duncia, J.V., Pease, L.J., Wong, P.C., Wexler, R.R., Johnson, A.L., Timmermans, P.B.M.W.M. Identification of angiotensin II receptor subtypes. Biochem Biophys Res Commun $165,196-203$ (1989).

Clozel, J.P., Holck, M., Osterrieder, W., Burkard, W., Daprada, M. Effects of chronic myocardial infarction on responsiveness to isoprenaline and the state of myocardial beta-adrenoceptors in rats. Cardiovasc Res 21, 688-695 (1987).

Cohn, J.N., Archibald, D.G., Zieche, S., Franciosa, J.S., Harston, W.E., Tristani, F.E., Dunkman, W.B., Jacobs, W., Francis, G.S., Flohr, K.H., Goldman, S., Cobb, F.R., Shah, P.M., Saunders, R., Fletcher, R.D., Loeb, H.S., Hughes, V.C., Baker, B. Effect of vasodilator therapy on mortality in chronic congestive heart failure. New Eng $J$ Med 314, 1547-1552 (1986).

Cohn, J.N. Inotropic therapy for heart failure. New Eng J Med 320, 729-731 (1989).

Colluci, W.S., Wright, R.F., Braunwald, E. New positive inotropic agents in the treatment of congestive heart failure. New Eng J Med 314, 290-358 (1986a).

Colluci, W.S., Wright, R.F., Braunwald, E. New positive inotropic agents in the treatment of congestive heart failure. New Eng J Med 314, 349-358 (1986b).

Consensus Trial Study Group. Effects of enalapril on mortality in severe congestive heart failure. Results of the cooperative North Scandinavian enalapril survival study (Consensus). N Eng J Med 316, 1429-1435 (1987).

Cooper IV, G., Kent, R.L., Mann, D.L. Load induction of cardiac hypertrophy. J Moll Cell Cardiol 21 (suppl V), 11-30 (1989).

Daemen, M.J.A.P., Lombardi, D.M., Bosman, F.T., Schwartz, S.M. Angiotensin II induces smooth muscle cell proliferation in the normal and injured rat arterial wall. Circ Res 68 (1991). 
DiBianco, R., Shabetai, R. Kostuk, W., Moran, J., Schlant, R.C., Wright, R.A. A comparison of oral milrinone, digoxin, and their combination in the treatment of patients with chronic heart failure. New Eng J Med 320, 677-683 (1989).

Drexler, H., Banhardt, U., Meinertz, T., Wollschlager, H., Lehmann, M., Just, H. Contrasting peripheral short-term and long-tirem effects of converting enzyme inhibition in patients with congestive heart failure. A double-blind placebo-controled trial. Circulation 79, 491-502 (1989).

Dzau, V.J. Implications of local angiotensin production in cardiovascular physiology and pharmacology. Am J Cardiol 59, 59A-65A (1987).

Grobbee, D.E., Hofman, A. (eds.) Epidemiologie van ziekten in Nederland. Wetenschappeliike uitgeverij Bunge, Utrecht, The Netherlands (1989).

Farah, A.E. historical perspectives on inotropic agents. Circulation 73(suppl 3), 4-9 (1986).

Fishbein, M.C., MacLean, D., Maroko, P.R., Experimental myocardial infarction in the rat. Am J Pathol 90, 57-70 (1978).

Francis, G.S., Goldsmith, S.R., Levine, B., Olivari, M.T., Cohn, J.N. The neurohumoral axis in congestive heart failure. An Int Med 101, 370-377 (1984).

Francis, G.S. Neurohumaral mechanisms involved in congestive heart failure. Am J Cardiol 55, 15A-21A (1985).

Genest, J. The atrial natriuretic factor. Br Heart J 56, 302-316 (1986).

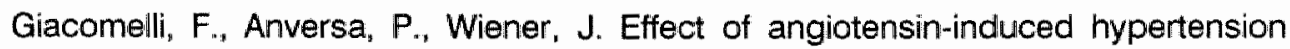
on rat coronary arteries and myocardium. Am J Pathol 84, 111-125 (1976).

Gorlin, R. Treatment of congestive heart failure: where are we going? Circulation 75 (suppl 4), 108-111 (1987).

Gorza, L. Mercadier, J.J., Schwartz, K., Thornell, L.E., sartore, S., Schiafinno, S. Myosin types in the human heart. Circ Res 54, 694-702 (1984).

Gravanis, M.B. Cardiovascular pathophysiology (eds.: Day, W., Ramos-Englis, M.) McGraw-Hill Inc., USA (1987).

Herman, M.V., Heinle, R.A., Klein, M.D. et al. Localized disorders in myocardial contraction: Asynergy and its role in congestive heart failure. N Eng $J$ Med 277, $222-227$ (1967).

Hochman, J.S., Bulkley, B.H. Expansion of acute myocardial infarction: An experimental study. Circulation 65, 1446-1450 (1982). 
Ito, Y., Suko, J., Chidsey, J.A. Intracellular calcium and myocardial contractility. V. Calcium uptake of sarcoplasmatic reticulum fractions in hypertrophied and failing rabbit hearts. J Moll Cell Cardiol 6, 237-247 (1974).

Izumo, S., Nadal-Ginard, B., Mahdavi, V. Protooncogene induction and reprogramming of cardiac gene expression produced by pressure overload. Proc Natl Acad Sci USA 85, 339-343 (1988).

Jackson, T.R., Blair, A.C.; Marshall, J., Goedert, M., Hanley, M.R. The mas oncogen encodes the angiotensin receptor. Nature 335, 437-440 (1988).

Jalil, J.E., Doering, C.W., Janicki, J.S., Pick, R., Shroff, S.G., Weber, K.T. Fibrillar collagen and myocardial stiffness in the intact hypertrophied rat left ventricle. Circ Res 64, 1041-1050 (1989).

Katz, A.M. Potential deleterious effects of inotropic agents in the therapy of chronic heart failure. Circulation 73(suppl 3), 184-190 (1986).

Katz, A.M. The myocardium in congestive heart failure. Am J Cardiol 63, 12A-16A (1989).

Katz, A.M. Cardiomyopathy of overload. New Eng J Med 3, 100-110 (1990a).

Katz, A.M. Angiotensin II: Hemodynamic regulator or growth factor? J Moll Cell Cardiol 22, 739-747 (1990b).

Keith, A. The evolution and action of certain muscular structures of the heart. Lancet i, 555-557 (1904).

Laragh, J.H. Endocrine mechanisms in congestive cardiac failure renin, aldosterone and atrial natriuretic hormone. Drugs 32(suppl 5), 1-12 (1986).

Leenen, F.H.H., Smith, D.L., Farkas, R.M., Reeves, R.A., Marques-Julio, A. Vasodilators and regression of left ventricular hypertrophy. Hydralazine versus prazosin in hypertensive humans. Am $J$ Med 82, 969-978 (1987).

Lejemtel, T.H., Sonnenblick, E.H. Should the failing heart be stimulated? New Eng J Med 310, 1384-1385 (1984).

Levine, T.B. Role of vasodilators in the treatment of congestive heart failure. Am J Cardiol 55, 32A-35A (1985).

Long, C.S., Kariya, K., Karns, L., Simpson, P.C. Trophic factors for cardiac myocytes. J Hypertens 8(suppl 7), S219-S224 (1990).

Meerson, F.Z. The failing heart: adaptation and de-adaptation (ed: Katz, A.M.). Raven Press, New York (1983). 
Merx, W., Yoon, M.S., Han, J. The role of local disparity on conduction and recovery on ventricular vulnerability to fibrillation. Am Heart $J 94,603-610$ (1977).

Michel, J-B., Lattion, A-L., Salzmann J-L, de Lourdes Cerol, M., Philippe, M., Camelleri, J-P., Corvol, P. Hormonal and cardiac effects of converting enzyme inhibition in rat myocardial infarction. Circ Res 62, 641-650 (1988).

Morano, I., Arndt, $H_{\text {. }}$ Gärtner, C., Rüegg, J.C. Skinned fibers of human atrium and ventricle: myosin isoenzymes and contractility. Circ Ries 62, 632-639 (1988).

Morris, M., Cain, M. Russell, A., Elliot, J.. Chalmers, J. Direct radioimmunoassay of human plasma atrial natriuretic peptide in various normal and pathophysiological states: increase in renal and cardiac failure during excercise. Clin Exp Theor Pract A9, 703-718 (1987).

Nadal-Ginard, B., Mahdavi, V. Molecular basis of cardiac performance. Plasticity of the myocardium generated through protein isoform switches. J Clin Invest 84 , $1693-1700$ (1989).

Nelson, G.I.C.. Silke, B., Ahuja, R.C. Hemodynamic trial of sequential treatment with diuretic, vasodilator, and positive inotropic drugs in left ventricular failure following acute myocardial infarction. Am Heart J 107, 1202-1209 (1984).

Olivetti, G., Capasso, J.M., Sonnenblick, E.H., Anversa, P. Side-to-side slippage of myocytes participates in ventricular wall remodeling acutely after myocardial infarction in rats. Circ Res 76, 23-34 (1990).

Packer, $M$. The role of vascdilator therapy in the treatment of severe chronic heart failure. Drugs 32(suppl 5), 13-26 (1986).

Packer, M., Leier, C.V. Survival in congestive heart failure during treatment with drugs with positive inotropic actions. Circulation 75(suppl 4), 55-63 (1987).

Parmley, W.W., Chatterjee, K. Congestive heart failure and arrhythmias: an overview. Am J Cardiol 57, 34B-37B (1986).

Peres, A.K., Flaim, S.F. Zelis, R. Cardiac receptors affect regional flow during acute infarction in conscious rats. J Auton Nerv Syst 19, 243-254 (1987).

Pfeffer, M.A., Pfeffer, J.M. Steinberg, C., Finn, P. Survival after an experimental myocardial infarction: beneficial effects of long-term therapy with captopril. Circulation $72,406-412(1985 a)$.

Pfeffer, J.M., Pfeffer, M.A., Braunwald, E. Influence of chronic captopril therapy on the infarcted left ventricle of the rat. Circ Res 57, 84-95 (1985b). 
Pieffer, M.A., Lamas, G.A. Vaughan, D.E., Parisi, A.F., Braunwald, E. Effect of captopril on progressive ventricular dilatation after anterior myocardial infarction. New Eng J Med 319, 80-86 (1988).

Pfeffer, M.A., Braunwald, E. Ventricular remodeling after myocardial infarction. Experimental observations and clinical observations. Circulation 81, 1161-1172 (1990).

Poole-Wilson, P.A., Buller, N.P., Lipkin, D.P. Regional blood flow, muscle strength and skeletal muscle histology in severe congestive heart failure. Am J Cardiol 62, $49 E-52 E$ (1988).

Raya, T.E., Gay, R.G., Lancaster, L., Aguirre, M., Moffett, C., Goldman, S. Serial changes in left ventricular relaxation and chamber stiffness after large myocardial infarction in rats. Circulation 77, 1424-1431 (1988).

$R e, R$. The myocardial intracellular renin-angiotensin system. Am J Cardiol 59, 56A. $58 \mathrm{~A}(1987)$.

Remme, W.J. Congestive heart failure. Pathophysiology and medical treatment. J Cardiovasc Pharmacol 8(suppl 1), 36-52 (1986).

Robbins, R.J., Swain, J.L. Modulation of cardiac hypertrophy by the c-myc protooncogene in transgenic mice (abstract). Circulation 80(suppl II), II-92 (1989).

Rogg, H., Schmid, A., de Gasparo, M. Identification and characterization of angiotensin II receptor subtypes in rabbit ventricular myocardium. Biochem Biophys Res Commun, accepted for publication, (1990).

Ruggie, N. Congestive heart failure. Med Clin North Am 70, 829-851 (1986).

Schelling, P., Ganten, D., Speck, G., Fischer, H. Effects of angiotensin II and angiotensin II antagonist salarasin on cell growth and renin in 3T3 and SV3T3 cells. J Cell Physiol 98, 503-514 (1979).

Schoemaker, R.G., Debets "J.J.M., Struyker-Boudier, H.A.J., Smits, J.F.M. Delayed but not immediate captopril therapy improves cardiac function in conscious rats, following myocardial infarction. J Moll Cell Cardiol. In press. (1991).

Schunkert, H., Dzau, V.J., Tang, S.S., Hirsch, A.T., Apstein, C.S., Lorell, B.H. Increased rat cardiac angiotensin converting enzyme activity and MRNA expression in pressure overload left ventricular hypertrophy. Effects on coronary resistance, contractility, and relaxation. J Clin Invest 86, 1913-1920 (1990).

Sharpe, D.N. Angiotensin converting enzyme inhibitors in heart failure: a case for earlier intervention? ACE Rep 59, 1-6 (1989). 
Simpson, $P$. Stimulation of hypertrophy of cultured neonatal rat heart cells through an alpha $a_{5}$-adrenergic receptor and induction of beating through an allpha $a_{5}$ and beta, adrenergic receptor interaction. Circ Res 56, 884-894 (1985).

Simpson, P. Protooncogenes and cardiac hypertrophy. Ann Rev Physiol 51, 189$202(1989)$.

Schelling, $P$., Fischer, H. Ganten, D. Angiotensine $\|$ and cell growth: a link to cardiovascular hypertrophy. J Hypertens $9_{t} 3-15$ (1991).

Starksen, N.F. Simpson, P.C., Bishopric, N., Coughlin, S.R., Lee, W.M.F., Escobeno, J.A., Williams, L.T. Cardiac myocyte hypertrophy is associated with Cmyc protooncogene expression. Proc Natl Acad Sci USA 83, 8348-8350 (1986).

Sweet, C.S., Emmert, S.E., Stabilito, I.I., Ribeiro, L.G.T. Increased survival in rats with congestive heart failure treated with enalapril. J Cardiovasc Pharmacol 10, 636$642(1987)$.

de Vries, P.J.F. Atrial natriuretic peptides, their role in cardiovascular homeostasis. PhD Thesis, Maastricht, (1990) ISBN 90-5291-030-8.

Weber, K.T., Janicki, J.S., Pick, R., Abrahams, C., Shroff, S.G., Bashey, R.I., Chen, R.M. Coilagen in the hypertrophied, pressure overioaded myocardium. Circulation 75(suppl II), II-40-1I-47 (1987).

Weber, K.T., Janicki, J.S., Shroff, S.G., Pick, R., Chen, R.M., Bashey, R.I. Collagen remodeling of the pressure overloaded, hypertrophied nonhuman primate myocardium. Circ Res 62, 757-765 (1988).

Weber, K.T., Pick, R., Jalil, J.E., Janicki, J.S., Carroll, E.P. Patterns of myocardial fibrosis. J Mol Cell Cardiol 21(suppl V), 121-131 (1989).

Wetzel, B., Hauel, N. New cardiotonic agents. A promising approach for treatment of heart failure. Trends Pharmacol Sci 9, 166-170 (1988). 
CHAPTER 2

MATERIALS AND METHODS 


\subsection{Animals}

A myocardial infarction (MI) was induced in adult male Wistar rats (Winkelmann, Borchen, F.R.G.) by ligation of the left anterior descending coronary artery. Nonoperated and sham-operated animals served as controls. All experiments were performed according to institutional guidelines.

\subsection{Surgery}

The animals were anesthetized with pentobarbital and ventilated by positive pressure through an endotracheal tube attached to a Harvard small animal respirator. Via a left-sided thoracotomy, the left descending coronary artery was ligated. After closing the chest, Lidocaine (Xylocaine, ASTRA, Rijswijk, The Netherlands) was given i.m. (2 mg.kg) to reduce ventricular arrhythmias. The sham procedure consisted of a superficial suture in the epicardium of the left ventricle.

\subsection{In vivo labeling of DNA synthesizing cells}

Starting 24 hours (chapter 3) or 7 days (chapters 5 and 6) before euthanasia, 5Bromo-2'-deoxyUridine (BrdU) (Serva, Heidelberg, F.A.G), was administered via an osmotic mini-pump (ALZET, 2001; Alza Corp., Palo Alto, CA, U.S.A.), implanted subcutaneously in the neck region. The infusion rate for Brdu was $2.3 \mathrm{mg} \cdot \mathrm{kg}$ ". day". Our own studies as well as information from the literature indicate that the data obtained with BrdU labeling correspond well with data on $\left[{ }^{3} \mathrm{H}\right]$ thymidine incorporation as detected by autoradiography (Van Furth and Van Zwet, 1988; Sugihara et al, 1986). 


\subsection{Tissue Processing}

The animals were sacrificed in deep ether anesthesia. The heart was arrested in diastole by injecting $1 \mathrm{ml} \mathrm{KCl}(1 \mathrm{M})$ into the inferior caval vein, and fixed by perfusion $(5 \mathrm{~min}$.) with $10 \%$ phosphate buffered formalin in $0.15 \mathrm{M} \mathrm{NaCl}$ at a pressure of $100 \mathrm{mmHg}$. After removal of the atria and large vessels the ventricles were weighed, fixed overnight in formalin and subsequently cut into 4 slices of 2 $\mathrm{mm}$, starting $2 \mathrm{~mm}$ superior to the apex.

The slices were dehydrated and embedded in paraplast via routine histological procedures, and $4 \mu \mathrm{m}$ sections were cut.

\subsection{Immunohistochemistry}

BrdU-labeled nuclei were visualized using an indirect enzyme labeled antibody technique (Schutte et al, 1987). Briefly, after rehydration of the sections and blocking of endogenous peroxidase, washing in phosphate buffered saline (PBS, $\mathrm{pH} 7.4,3 \times 5 \mathrm{~min}$ ) and digestion in $0.1 \mathrm{mg} / \mathrm{ml}$ pepsin (Boehringer, Mannheim, F.R.G.) in $0.1 \mathrm{~N} \mathrm{HCL}\left(30 \mathrm{~min} 37^{\circ} \mathrm{C}\right)$, the sections were incubated in $2 \mathrm{~N} \mathrm{HCL}$ (30 $\left.\min 37^{\circ} \mathrm{C}\right)$ and washed in $0.1 \mathrm{M}$ sodium tetraborate $(\mathrm{pH} 8.5)$. Incubation with a monoclonal anti-BrdU antibody (Schutte et al, 1987), ( 1 hr $37^{\circ} \mathrm{C}$ ) was followed by incubation with peroxidase conjugated rabbit anti-mouse IgG (Dakopatts, Glostrup. Denmark), for $1 \mathrm{hr}$ at room temperature. $3,3^{\prime}$ diaminobenzidine was used as chromogen and the sections were counterstained with hematoxylin (FIG.1). Control sections were incubated with an indifferent monoclonal antibody (Leu-2b, Becton \& Dickinson). 


\subsection{Determination of the fraction of BrdU labeled nuclei}

In the study described in chapter 3 , the number of BrdU positive nuclei per unit area of the non-infarcted myocardium of the left (septum) and right ventricle was determined by counting labeled nuclei in 3 randomly chosen fields of vision $(0.435$ $\mathrm{mm}^{2}$ encompassing $\approx 750-900$ nuclei) at high magnification $(400 \mathrm{X})$. We observed regional differences in BrdU labeling: the endo- and epicardial areas showed increased labeling, compared to the mid part of the left or right ventricular myocardium. Therefore, the endo- and epicardial areas were excluded from the counting procedure.

In the studies described in chapters 5 and 6 the percentage of BrdU positive nuclei in the non-infarcted myocardium of the left- and right ventricle was determined microscopically with an eyepiece grid (400 X magnification). In each section, 4 randomly chosen fields (encompassing $\approx 600-800$ nuclei) in the septum and in the right ventricular wall were counted.

One purpose of the study, described in chapter 3 was to determine the time course of increased DNA synthesis in the ventricular myocardium, starting 4 days after myocardial infarction. Therefore, all animals were given BrdU, starting 24 hours before they were sacrificed. To determine an increase in the BrdU labeling fraction in Ml animals, counting of BrdU labeled nuclei per fields of vision and comparison with controls is acceptable. A labeling index was determined in the studies described in chapters 5 and 6.

One purpose of the studies, described in chapters 5 and 6 , was to determine differences in ventricular BrdU labeling in MI animals, which were either treated or non-treated. This was done at the time points of increased ventricular labeling, 
determined in the experiment described in chapter 3 . Therefore, to detect small differences in labeling, all animals were given BrdU starting 4 week before they were sacrificed.

In the study described in chapter 3 a double immunostaining procedure was performed using the anti-BrdU antibody and an anti-laminin antibody, to identify the nature of the BrdU labeled nuclei. To this end incubation with the anti-BrdU antibody was followed by a biotinylated sheep anti-mouse lgG (Amersham, UK), an avidine/biotin - peroxidase complex (Vector, Burlingam, CA 94010 USA) and DAB staining. The second staining sequence involved incubation with an anti-rat-laminin polyclonal antibody (a generous gift from Dr. Wewer, Stockholm, Sweden; Wewer, 1984) followed by peroxidase conjugated swine anti rabbit IgG (Dakopatts, Glostrup, Denmark) and DAB staining. Finally, the sections were counterstained with hematoxylin. Through staining of the basement membranes surrounding the cardiomyocytes, BrdU labeled nuclei could be identified as of cardiomyocyte or interstitial origin.

\subsection{Morphometry to determine ventricular and cardiomyocyte dimensions}

The morphometric parameters (FIG. 2) were determined in each of the 4 slices per heart, using a graphic tablet, optically projected into a standard microscope and coupled to a computer (KONTRON, DIGITAL), and mean values were calculated. For morphometry, the sections were stained with the AZAN technique as described by Heidenhain (1915) (FIG. 3) and as modified by Vliegen et al (1987).

The infarct size (INF) was determined as a percentage of the circumference of the left ventricle (Fishbein et al, 1978). The area of the non-infarcted part of the 
left ventricle (LA) was used as a measure for the volume of the myocardium after MI. LA was calculated as the product of the mean of the measured non-infarcted endo- and epicardial lengths (LLV) and mean septum thickness (ST).

To establish the relative increase in left ventricular myocardial volume, LA was corrected for the reduction caused by the infarct (LAC) (FIG. 2). Since the starting body weights of non-treated infarct and DuP 753 treated animals were slightly, but significantly different, this parameter was also corrected for body weight (LAIC). LAC and LAIC were used as indicators for hypertrophy of the non-infarcted left ventricular wall after MI. As indicator for left ventricular dilatation we used the inner circumference (ICL) of the left ventricle (FIG. 2).

The volume of the right ventricle is reflected in the right ventricular wall area (RA) (FIG. 2). RA was calculated as the product of the mean of endo- and epicardial lengths of the right ventricular wall (LRV) and the mean right ventricular wall thickness (RT). RA was used as an indicator for hypertrophy of the right ventricular wall after MI.

As an indicator for right ventricular dilatation we used the inner circumference (ICR) of the right ventricle (FIG. 2).

The equations used for the calculations are:

$\mathrm{LA}\left(\mathrm{mm}^{2}\right)=\mathrm{LLV} \cdot \mathrm{ST}$

LAIC $\left(\mathrm{mm}^{2}+100 \mathrm{~g}^{\prime \prime}\right)=\frac{\text { LA } \cdot 100}{100 \cdot \text { INF }} \cdot \frac{100}{\text { BW }}$

RA $\left(\mathrm{mm}^{2}\right)=$ LRV . RT 


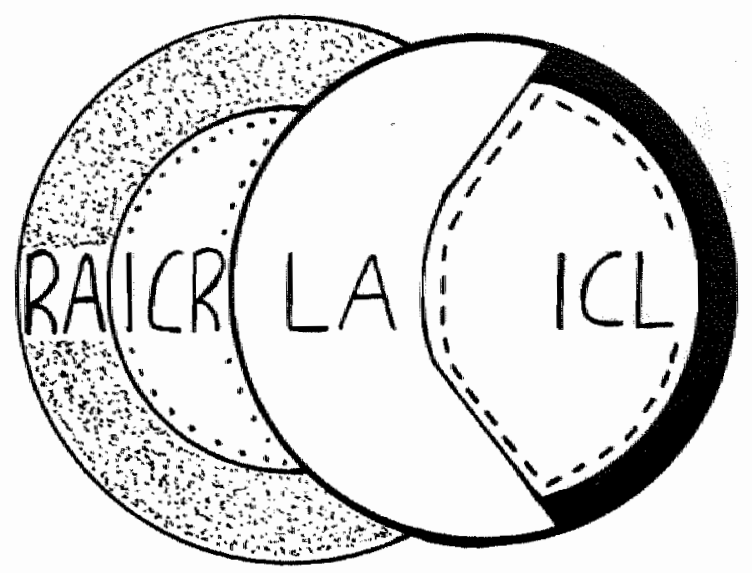

FIG. 2; Left (LA) and right (RA) ventricular wall area. Left (ICL) and pight (ICR) ventricular inner circumference. Parameters used for determination of left and right ventricular hypentrophy and dillatation.

The modified AZAN staining procedure visualizes intercalated disks (FIG. 4), permitting morphometric analysis of individual cardiomyocyte dimensions. Width and area were measured in 50 cardiomyocytes with an intercalated disk on both sides of a cell with a central nucleus. Myocyte volume was calculated from these parameters (Vliegen et al, 1987). Assuming a cylindrical shape, cardiomyocyte volume is represented by area $x$ width $x \pi / 4$ (Korecky and Rakusan, 1978).

\subsection{Collagen staining}

First, the sections were incubated $(5 \mathrm{~min}$ ) with $0.2 \%(\mathrm{w} / \mathrm{v})$ aqueous phosphomolybdic acid (Dolber and Spach, 1987). Staining was performed in $0.1 \%$ Sirius red F3BA (C.I. 35780, Polysciences, Northampton, UK), in saturated aqueous picric acid (90 min.) followed by washing ( $2 \mathrm{~min}$.) with $0.01 \mathrm{~N} \mathrm{HCl}$, clearing and mounting. 


\subsection{Morphometry to determine the collagen positive area}

The proportion of Sirius red stained myocardial tissue (FIG. 5) was evaluated using an image analyzer (CAS 200, Inc., Becton and Dickinson) and its Quantitative Nuclear Antigen program. The program operates with two masks. One mask defines a threshold to determine the total area of the measured parts of the section. The other mask defines a threshold, which determines the Sirius red stained area, which is expressed as a percentage of the total measured sectional area.

\subsection{Data analysis}

Since a small infarction of the left ventricle has no effects on the hemodynamic function of the left- or right ventricle (Schoemaker, 1989; Schoemaker et al, 1990), infarct animals with an infarct size of less than $21 \%$ were excluded from the study. The following statistical methods were used to compare data in the various experimental groups.

1) Student's t-test for unpaired observations. This method was used to compare maximally two groups of unpaired values.

2) One-way analysis of variance and a modified t-test for overall comparisons of experimental groups, following the Bonferroni method and for multiple comparisons to the same control group, following Dunnett's test (Wallenstein et al, 1980). This method was used to compare more than two groups of unpaired values.

Data are presented as means $\pm S E M$, unless indicated otherwise. Differences were regarded to be statistically significant if $p<0.05$. 


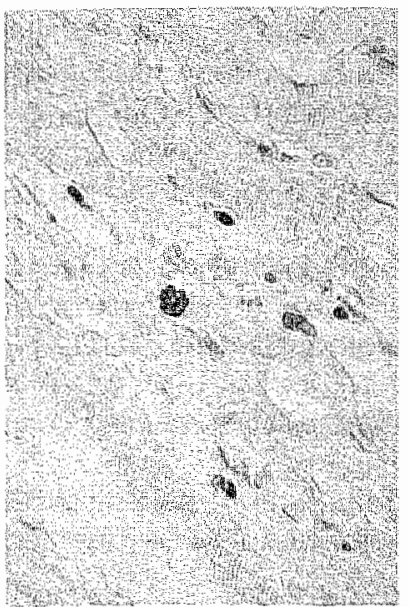

FIG. 1

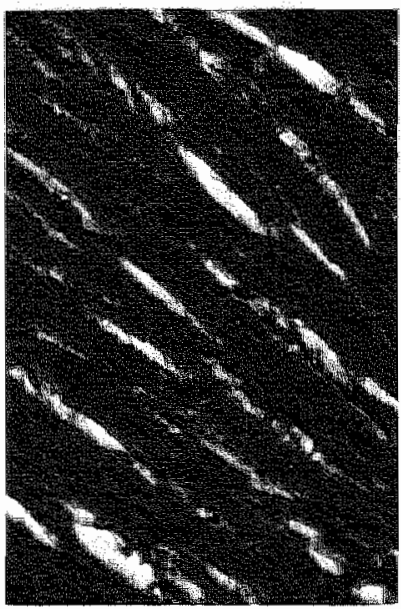

FIG. 4

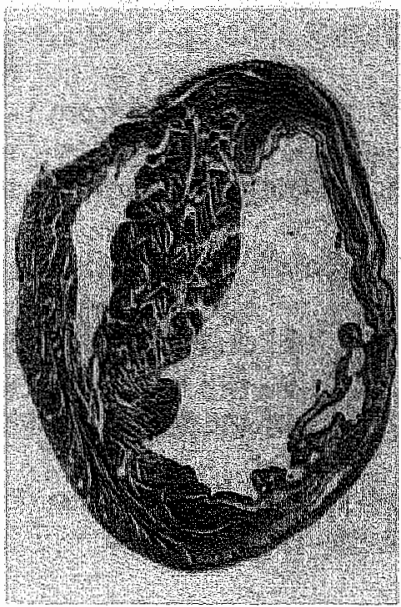

F॥G. 3

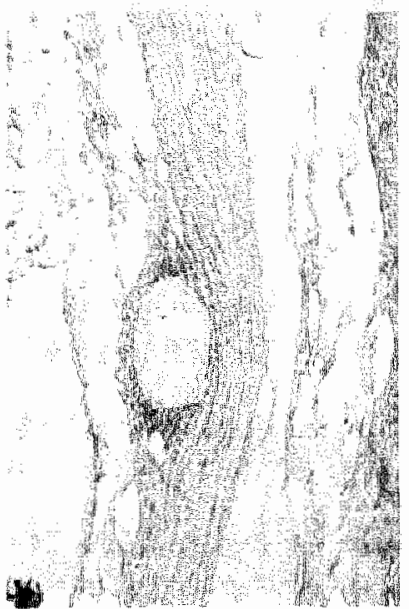

F|G. 5

FIG. 1: Brdu labeled nuclei in the left verntricle of a rat heart $(400 \times)$.

FIG. 3; AZAN stained section of a rat heart with an infarction ot the left ventricle (100 $x)$.

Fi6. 4; Modified AZAN stained section of a rat heat. Intercallated disks of cardiomvocytes are clearly visible $(400 \mathrm{C})$.

FIG. 5; Sirus red stained section of a rat heart, demonstrating collagen containing areas of the myocardium (400 $X)$ 


\section{Drugs used in this thesis}

In the different chapters the following drugs were used.

Captopril: a generous gift from Bristol-Myers Squibb, (Woerden, The Netherlands).

DuP 753: 2-n-butyl-4-chloro-5-hydroxy-methyl-1-[2'-(1H-tetrazol-5-yl)

bipheny(-4-yl)methyl] imidazole potassium salt, a generous gift from Dr. P.B.M.W.M.

Timmermans (E.ll du Pont de Nemours \& Company, Wilmington, Deleware, U.S.A).

Hydralazine: obtained from Ciba-Geigy (Arnhem, The Netherlands).

Lidocaine: obtained from Astra (Rijswijk, The Netherlands). 


\section{REFERENCES}

Dolber, P.C., Spach, M.S. Picrcsirius red staining of cardiac muscle following phosphomolybdic acid treatment. Stain Technol 62, 23-26 (1987).

Fishbein, M.C., Maclean, D., Maroko, P.R. Experimental myocardial infarction in the rat. Am J Pathol 90, 57-70 (1978).

Heidenhain, M. Uber die Mallorysche Bindgewebsfarbung mit Karmin und Azokarmin als Vorfarben. Z Wiss Mikrosk 32, 361-372 (1915).

Korecky, B., Rakusan, K. Normal and hypertrophic growth of the rat heart: Changes in cell dimensions and number. Am J Physiol 234, 123-128 (1978).

Schoemaker, R.G. Experimental heart failure in rats: hemodynamic studies on pathophysiology and therapy. PhD Thesis Maastricht, (1989), ISBN 90-5291-013-8

Schoemaker, R.G., Urquhart, J., Debets J.J.M., Struyker Boudier, H.A.J, Smits, J.F.M., Acute hemodynamic effects of coronary artery ligation in conscious rats. Basic Res Cardiol 85, 9-20 (1990).

Schutte, B., Reynders, M.M.J., Bosman, F.T., Blijham, G.H. Studies with antibromodeoxyuridine antibodies II. Simultaneous detection of antigen expression and DNA synthesis by in vivo labeling of mouse intestinal mucosa. $J$ Histochem Cytochem 35, 371-374 (1987).

Sugihara, H., Hattori, T., Fukuda, M. Immunohistochemical detection of bromodeoxyuridine in formalin-fixed tissues. Histochemistry 85, 193-195 (1986).

Van Furth, R., Van Zwet, T.L. Immunocytochemical detection of 5-bromo-2deoxyuridine incorporation in individual cells. J Immunol Meth 108, 45-51 (1988).

Vliegen, H.W., van der Laarse, A, Huysman, J.A.N., Wijnvoord, E.C. Mentar, M. Cornelisse, C.J. "Eulderink, F. Morphometric quantification of myocyte dimensions validated in normal growing rat hearts and applied to hypertrophic human hearts. Cardiovasc Res 21, 352-357 (1987).

Wallenstein, S., Zucker, C.O.L., Fleiss, J.L. Some statistical methods, usefull in circulation research. Circ Res 47, 1-9 (1980).

Wewer, U. Induction of rat yolk sac carcinoma with consistent pattern of laminin, entactin, and type IV collagen biosynthesis. Acta Path Microb Immun Scand A 92, 275-283 (1984). 



\section{CHAPTER 3}

STRUCTURAL ALTERATIONS IN THE RAT HEART AFTER MYOCARDIAL INFARCTION 


\subsection{INTRODUCTION}

The myocardial hypertrophic response occurring in hypertension has been subject of many studies (Dahlơf, 1988). Changes occur both at the level of the myocytes and the myocardial interstitium (Weber, 1989). In the interstitium a proliferative response has been observed (Morkin et al, 1968). Furthermore, Weber and coworkers (1989) have extensively documented changes of quality and quantity in myocardial collagen. These studies suggest that the increase in DNA synthesis by pressure overload hypertrophy is associated with collagen synthesis in interstitial cells.

Far less is known about the exact nature of changes occurring at these levels following myocardial infarction. Several studies have analyzed the development of structural alterations in the myocardium, following an infarction (Anversa et al, 1985, 1986; Rubin et al 1990). Again, these alterations include changes in both the cardiomyocyte and interstitial compartment. Volume increase of individual cardiomyocytes leads to myocarcial hypertrophy in the non-infarcted ventricular tissue. This hypertrophy restores ventricular mass to control levels (Anversa et al, 1986).

Changes in the interstitium include induction of collagen synthesis in the non-infarcted ventricle, early after Ml (Michel et al, 1988; Bishop et al, 1990). Although another form of injury (i.e. electrical) of the myocardium results in DNA synthesis in myocardial cells (Nag et al, 1983), it has not been extensively studied

whether or not these phenomena also occur after myocardial infarction. Rumyantsev and Mirakyan (1976) showed increased "H-thymidine uptake in isolated atrial muscle cells after ligation of the left coronary artery in rats. 
The present study was designed to evaluate the structural changes in the cardiac tissue during a period of five weeks after infarct induction in rats. To this end we studied the development of myocardial hypertrophy and dilatation and the associated changes in DNA synthesis of cardiac cells, as well as the amount of interstitial collagen in both the left and right ventricle at several time-points after induction of a myocardial infarction.

\subsection{EXPERIMENTAL PROTOCOLS}

\subsubsection{Morphometry and quantitation of collagen content}

Morphometric parameters and myocardial collagen content was studied in animals with a myocardial infarction (MI) induced $4(n=11), 7 \quad(n=11), 14 \quad(n=9), 21 \quad(n=8)$ and $35(n=8)$ days before they were sacrificed. Sham-operated groups of $7(n=4)$, $14(n=4), 21(n=4)$ and $35(n=4)$ days served as control (SHAM day $7,14,21$ and 35).

\subsubsection{In vivo labeling of DNA synthesizing cells}

DNA synthesis was studied in 5 groups of MI animals $(n=8-11)$ at different time points (day 4, 7, 14, 21 and 35). A non-operated group of 6 animals served as contrals. Starting 24 hours before euthanasia BrdU was administered via an osmotic mini-pump (chapter 2), implanted subcutaneously in the neck region. The infusion rate for BrdU was $23 \mathrm{mg} \mathrm{kg}^{\prime \prime} \cdot \mathrm{day}^{\prime}$.

The methods used, including surgery, tissue processing, morphometry, determination of Brdu labeled nuclei, histochemistry to visualize collagen and morphometry to determine the collagen positive area, are described in chapter 2. 


\subsection{RESULTS}

\subsubsection{Infarct size, body weight and heart weight}

The mean infarct size for all animals was $40 \pm 11 \%$ (mean $\pm s d, n=47$ ). Body weight for Mi animals was lower than sham animals at 7 and 14 days (day $7 ; \mathrm{M}$ : $313 \pm 8 \mathrm{~g}$ and sham: $359 \pm 7 \mathrm{~g}, \mathrm{p}<0.05$, day $14 ; \mathrm{Ml}: 330 \pm 5 \mathrm{~g}$ and sham: $375 \pm$ $8 \mathrm{~g}, \mathrm{p}<0.05)$. Total heart weight was not different between sham and infarct animals at the time points measured.

\subsubsection{Left and right ventricular wall area}

After infarction the non-infarcted left ventricular wall area was decreased throughout the experimental period, although statistical significance was not obtained at two weeks (data not shown). Since this parameter does not take thinning of the infarct area into account it may mask actual hypertrophy in the non-infarcted part of the left ventricle. Therefore we corrected this parameter for infarct size, as indicated in chapter 2 ( $L A C)$. After correction it increased significantly with $36 \%$ at day 7 and $41 \%$ at day 14 (FIG. 1A) At five weeks the difference between infarct- and sham animals had disappeared (FIG. 1A).

The right ventricular wall area also increased significantly in infarct animals (FIG.

1B). This was only apparent during the first three weeks after infarct induction and could no longer be detected at five weeks. 

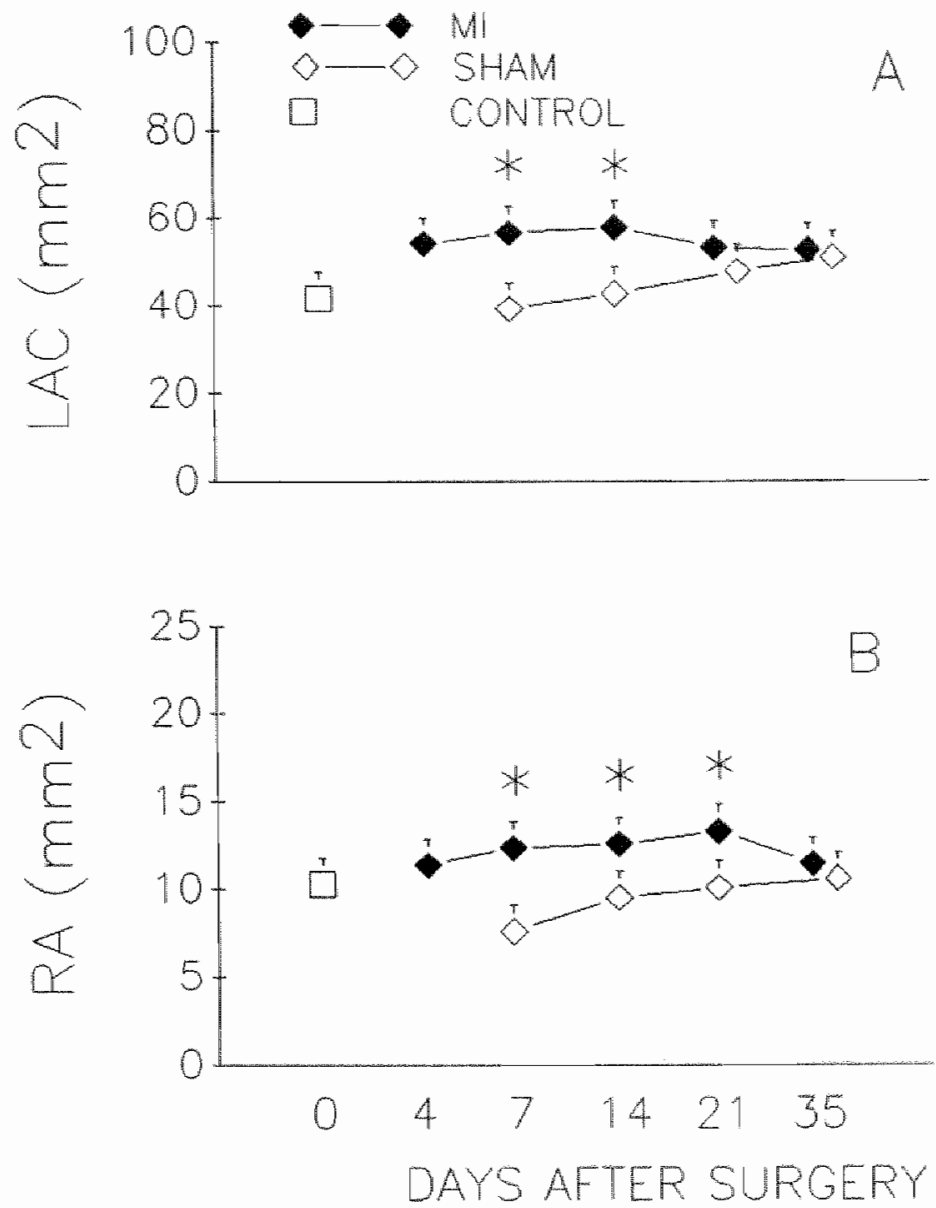

FIGS. IA and B. LEFT VENTRICULAR WALL AREA CORRECTED FOR INFAFCT SIZE (LAC) and FIGHT VENTRICULAR WALL AREA (RA); Control and 4, 7, 14,21 and 35 days after MI. ${ }^{*} p<0.05 ; \mathrm{MI}$ versus sham 


\subsubsection{Left and right ventricular inner circumference}

The inner circumference of the left ventricle was increased over the whole 5 week study period ( $F / G .2 A)$, although no statistical significance was achieved at 3 weeks after infarction.

The changes in the inner circumference of the right ventricle after infarction were variable. A decrease was found at one week, an increase at three weeks and no differences were observed at five weeks (FIG. 2B).

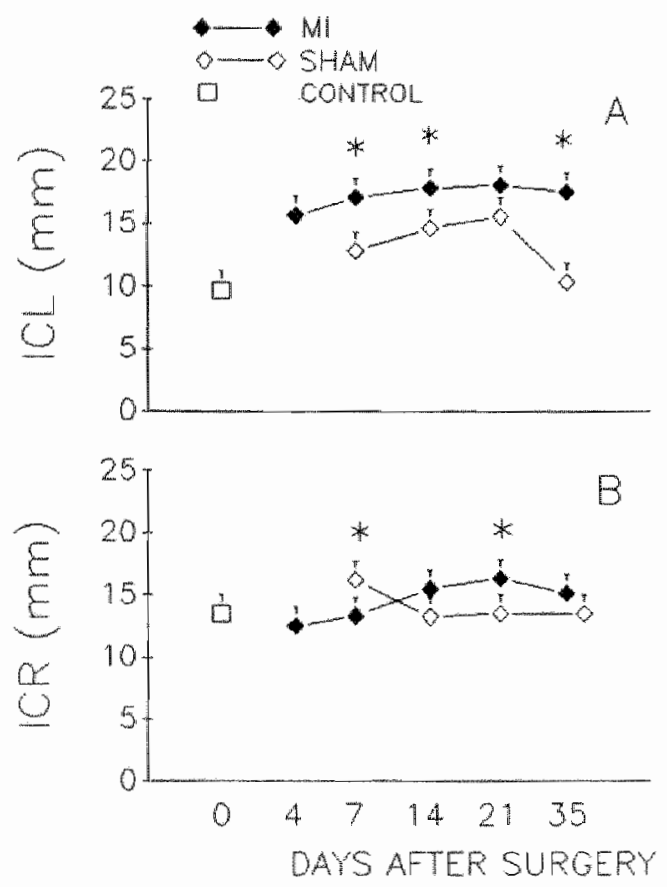

FIGS. 2A and B: INNEF CARCUMFERENCE of the LEFT (ICL) and the FIGHT (ICR) VENTAICLE; control and 4, 7. 14, 21 and 35 days after M! * $P<0.05$; Mi versus sham. 


\subsubsection{Left and right ventricular cardiomyocyte volume}

Two weeks after infarct induction the volume of the cardiomyocytes of infarct animals was significantly increased in both ventricles (TABLE 1). Five weeks after surgery, however, only the volume of right ventricular cardiomyocytes was increased, while no increase was observed in cardiomyocytes of the left ventricle.

TABLE 1

\begin{tabular}{|l|l|l|l||}
\hline & & LEFT VENTRICLE & FIGHT VENTRICLE \\
\hline cardiomyocyte & & $\begin{array}{l}\text { volume } \\
\left(\mu \mathrm{m}^{3} \cdot 10^{3}\right)\end{array}$ & $\begin{array}{l}\text { volume } \\
\left(\mu \mathrm{m}^{3} \cdot 10^{3}\right)\end{array}$ \\
\hline Control $(\mathrm{N}=4)$ & dlay 0 & $20.8 \pm 0.3$ & $14.3 \pm 0.9$ \\
\hline Sham $(\mathrm{N}=4)$ & day 14 & $17.1 \pm 1.7$ & $11.9 \pm 1.1$ \\
\hline MI $(\mathrm{N}=6)$ & day 14 & $36.0 \pm 1.7^{*}$ & $28.7 \pm 4.6^{*}$ \\
\hline Sham $(\mathrm{N}=4)$ & day 35 & $31.9 \pm 2.2$ & $16.3 \pm 1.3$ \\
\hline MI $(\mathrm{N}=6)$ & day 35 & $34.9 \pm 2.2$ & $27.0 \pm 2.9^{\circ}$ \\
\hline \hline
\end{tabular}

TABLE :- CARDIOMYOCYTE VOLUME of the LEFT and RIGHT VENTRICLE, I4. and 35 days atter MI "p<0.05. Mi versus sham. 


\subsubsection{Left and right ventricular DNA synthesis}

The number of BrdU labeled nuclei increased significantly at days 7 and 14 in the left ventricle and at day 7 in the right ventricle (FIGS. 4A and B). At 14 days the number of positive nuclei in the left ventricle had increased to $61 \pm 6 \cdot\left(\mathrm{mm}^{-2}\right)$ resp. (controls: $37 \pm 6 \cdot\left(\mathrm{mm}^{2}\right)$ ). This was largely due to labeling of non-cardiomyocyte nuclei $\left(98.2 \pm 0.3\right.$ and $98.6 \pm 0.4 \cdot\left(\mathrm{mm}^{2}\right)$ in the left and right ventricular myocardium respectively. FIG 3$)$, as measured at 14 days after $M I I(n=6)$. A total of 800 BrdU labeled nuclei was counted per ventricle in each animal. These data indicate that less than $2 \%$ of the DNA synthesizing cells are cardiomyocytes.

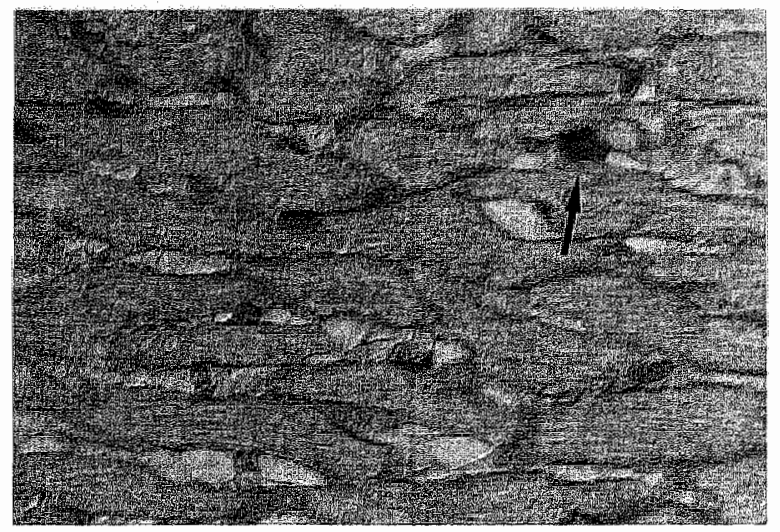

FIG. 3: Dotection of the BrdU label primarlly in nuclei located outside the cardiomyocyte basement membrane. Which is visualized using a polyctonall antibody directed against laminin (tor immunohistochemistry methods; chapter 2).

\subsubsection{Left and right ventricular collagen content}

One week after infarct induction, the amount of collagen was already increased in the non-infarcted part of the left and right ventricle and this was sustained until five weeks after MI (FIG. 4C and D). 
The sirius red positive area was maximall at 14 days after $\mathrm{Ml}$ and was comparable in both ventricles (left ventricle; sham: $1.5 \pm 0.1 \% ; \mathrm{Ml}: 8.5 \pm 0.5 \%$; right ventricle; sham: $2.8 \pm 0.2 \%$; Ml: $9.1 \pm 0.7 \%$ ).
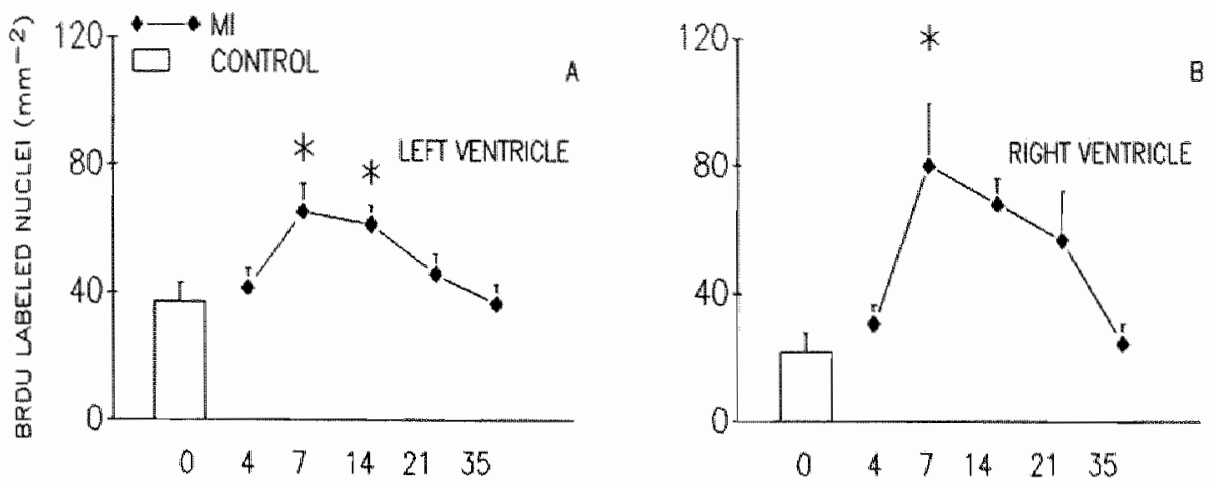

C
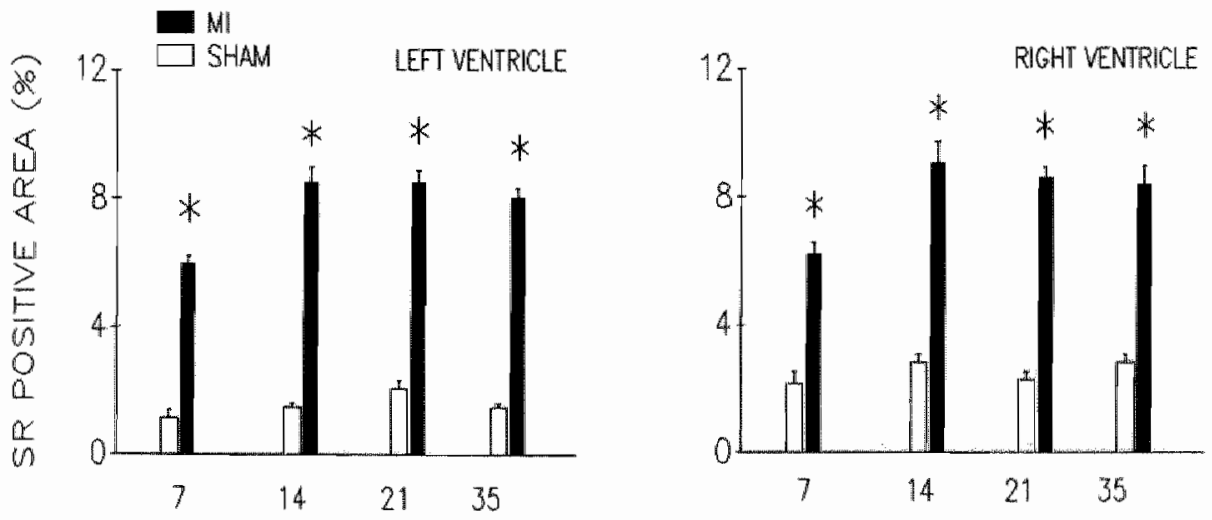

DAYS AFTER SURGERY

FIGS. 4A and B; BRDU LABELED NUCLEI of the LEFT and RIGHT VENTRICLE; control and 4, 7, 14, 21 and 35 days after M..* $P<0.05$; MI wersus control.

FIGS. 4C and D; SHRIUS RED (SP) POSITIVE AREA of the LEFT and RIGHT VENTRICLE: 7, 14,21 and 35 deys atter MI.* $p<0.05$; Ml versus sham. 


\subsection{DISCUSSION}

The present study was performed to investigate the structural alterations in both cardiac ventricles following a myocardial infarction $(\mathrm{Ml})$ in rats. A transient increase in the myocardial wall area is observed in both the left and right ventricle. This is already discernible in the first week after MI and is sustained up to the third week.

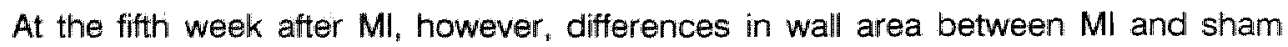
animals are no longer observed. In parallel with the increased myocardial wall area, the cardiomyocytes appear enlarged. Furthermore a transient increase in DNA synthesis, mainly of cardiac interstitial cells in the myocardium, occurs along with a sustained increase in collagen content. Finally, early after MI left ventricular dilatation is observed, which is sustained throughout the experiment, whereas in the right wentricle a transient dilatation is observed 2-3 weeks after MI.

The increased myocardial wall area is suggestive of myocardial hypertrophy, which would imply an increased cardiomyocyte mass. This is supported by the observation that the volume of individual cardiomyocytes is enlarged, suggesting cardiomyocyte hypertrophy. However, cardiomyocyte hypertrophy does not explain the transient nature of the increased myocardial volume. Alternative possibilities for the observed increase in ventricular area are intra- and intercellular edema, hyperplasia of myocardial interstitial cells and an increase in extracellular matrix (collagen). Intra- and intercellular edema (Schoemaker, 1989; Greve et al, 1988) which resolves in time, may be an important factor, but our data allow neither confirmation nor rejection of this possibility. Usually, edema is a temporary phenomenon and this would be in keeping with the transient nature of the increased myocardial volume. 
The alternative explanation, i.e. development of hyperplasia of interstitial cells, is supported by the observed transient rise in DNA synthesizing activities. An increased number of interstitial cells could go along with increased collagen deposition in the myocardial extracellular matrix, as is supported by our data. Newly deposited collagen tends to reduce in volume with time, due to continued crosslinking (Blumenfeld and Seifter, 1990) which would be in keeping with the transient nature of the increase in myocardial volume. Taken together, our data suggest that myocardial edema in the reparative phase after MI may lead to a transient increase in myocardial volume, whereas a more permanent alteration is caused by cardiomyocyte hypertrophy and increased interstitial mass.

The observed increase in proliferative activity and collagen content in the myocardial interstitium leads to two questions. The first concerns the mechanism which is responsible for triggering the proliferative activity of the interstitial fibroblasts. Firstly, a direct effect of tissue necrosis and repair should be considered. The most striking proliferative activity subsequent to $\mathrm{MI}$ is noted in the area surrounding the infarction and in the subendocardial region of the left ventricle. Such a mechanism would not explain interstitial proliferative activity distant from the site of the infarction, as e.g. in the right ventricle. A direct effect can therefore not be the only explanation. Another possibility would be the involvement of the sympathetic nervous system, which is activated after MI due to the reduced cardiac output (Katz, 1990). Supportive evidence is provided by experiments which show that $\beta$-adrenergic receptor agonists (e.g. isoprenaline) induce subendocardial fibrosis (Jalil et al, 1989). Finally, a role of the renin-angiotensin system should be contemplated. It has been suggested that All enhances endothelial permeability in 
the coronary vasculature (Giacomelli et $\mathrm{al}{ }^{1976)}$ ) as a result of which mitogens, such as platelet-derived-growth factor (PDGF), could gain access to the interstitium and induce fibroblast proliferation (Weber et al, 1989). Alternatively, angiotensin II itself may be a factor responsible for fibroblast proliferation (Schelling et al, 1979).

A second question is what the functional consequences are of the increased myocardial interstitium. Our data indicate that ventricular dilatation ${ }^{\prime}$ which reflects cardiac insufficiency (Pfeffer and Braunwald, 1990), occurs in parallel with the increase in interstitial mass. Ventricular dilatation would lead to increased wall stress, which might be an additional triggering factor in the proliferative reaction of the interstitium (Michel et al, 1988) and in the increased collagen content. This could lead to increased tensile strength of the myocardium (Raya et al, 1988; Borget et al, 1990), improvement of the cardiac dilatation, reduced wall stress and finally improved cardiac function.

In summary, our data indicate that ventricular dilatation early after $\mathrm{Ml}$ is paralleled by the proliferation of interstitial fibroblasts, deposition of collagen and cardiomyocyte hypertrophy. The mechanisms responsible for these processes have not been completely resolved. 


\section{REFERENCES}

Anversa, P., Loud, A.V., Levicky, V., Guideri, G. Left ventricular failure induced by myocardial infarction. I. Myocyte hypertrophy. Am J Physiol 248, H876-882 (1985).

Anversa, P., Beghi, C., Kikkawa, Y., Olivetti, G. Myocardial infarction in rats. Infarct size, myocyte hypertrophy, and capillary growth. Circ Res 58, 26-37 (1986).

Bishop, J.E., Greenbaum, R., Gibson, D.G., Yacoub, M., Laurent, G.J. Enhanced deposition of predominantly type I collagen in myocardial disease. J Moll Cell Cardiol 22, 1157-1165 (1990).

Blumenfeld, O.O., Seifter, S. Biochemistry of connective tissue with special emphasis on the heart. Robinson, T.F., Kinne, R.K.H. (eds.): Cardiamyocyt-connective tissue interactions in health and disease. Issues biomed. Basel, Karger 13, 5-36 (1990).

Borg, T.K.. Terracio, L. Interaction of the extracellular matrix with cardiac myocytes during development and disease. Robinson, T.F., Kinne, R.K.H. (eds.): Cardiomyocyte-connective tissue interactions in health and disease. Issues Biomed. Basel, Karger, 13, 113-129 (1990).

Dahlöf, B. Factors involved in the pathogenesis of hypertensive cardiovascular hypertrophy. A review. Drugs 35(suppl 5), 6-26 (1988).

Giacomelli, F., Anversa, P., Wiener, J. Effect of angiotensin-induced hypertension on rat coronary arteries and myocardium. Am J Pathol 84, 111-125 (1976).

Greve, G., Rotevatn, S., Grong, K., Stangeland, L. Cellular morphometric changes in cat hearts subjected to three hours of regional ischemia. Virc Arch A Pathol Anat Histopathol 412, 205-213 (1988).

Jalil, J.E., Janicki, J.S., Pick, R., Abrahams, C., Weber, K.T. Fibrosis-induced reduction of endomyocardium in the rat after isoproterenol treatment. Circ Res 65 , 258-264 (1989).

Katz, A.M. Cardiomyopathy of overload. New Eng J Med 3, 100-110 (1990).

Michel, J-B., Lattion, A-L., Salzmann, J-L., de Lourdes Cerol, M., Phillippe, M., Camelleri, J-P., Corvol, P. Hormonal and cardiac effects of converting enzyme inhibition in rat myocardial infarction. Circ Res 62, 641-650 (1988).

Morkin, E., Ashford, T.P. Myocardial DNA synthesis in experimental cardiac hypertrophy. Am J Physioll 215, 1409-1413 (1968).

Nag, A.C., Carey, T.R., Cheng: M. DNA synthesis in rat heart cells after injury and regeneration of myocardia. Tiss \& Cell 15, 597-613 (1983). 
Pfeffer, M.A., Braunwald, E. Ventricular remodeling after myocardial infarction. Circ Res 81, 1161-1172 (1990).

Raya, T.E., Gay, R.G., Lancaster, L., Aguirre, M., Moffett, C., Goldman, S. Serial changes in left ventricular relaxation and chamber stiffness after large myocardial infarction in rats. Circulation $77,1424-1431$ (1988).

Rubin, S.A., Fishbein, M.C. Effect of chemical sympathectomy on cardiac hypertrophy and hemodynamics following myocardial infarction in the rat. Am $\mathrm{J}$ Cardiovasc Pathol 3, 45-53 (1990).

Rumyantsev, P.P., Mirakyan, V.O. Increased activity of DNA synthesis and mitosis in rat atrial muscle cells under ventricular myocardial infarction and local injuries of auricles. Vir Arch Cell Pathol 20, 329-342 (1976).

Schelling, P., Ganten, D., Speck, G., Fischer, H. Effects of angiotensin II and angiotensin II antagonist salarasin on cell growth and renin in 3T3 and SV3T3 cells. J Cell Physiol 98, 503-514 (1979).

Schoemaker, R.G. Experimental heart failure in rats: hemodynamic studies on pathophysiology and therapy. Thesis Maastricht, (1989), ISBN 90-5291-013-8

Weber, K.T., Pick, A., Jalil, J.E., Janicki, J.S., Carroll, E.P. Patterns of myocardial fibrosis. J Mol Cell Cardiol 21 (Suppl V), 121-131 (1989). 
CHAPTER 4

EFFECTS OF EARLY AND DELAYED CAPTOPRIL TREATMENT ON STRUCTURAL ALTERATIONS IN THE RAT HEART AFTER MYOCARDIAL INFARCTION 


\subsection{INTRODUCTION}

As was already shown in the previous chapter, acute MI induces alterations in the structure of both the infarcted and non-infarcted regions of the heart. These alterations, also referred to as cardiac remodeling, can affect the function of the heart and as such the prognosis of the patient. For instance, dilatation of the left ventricular cavity is seen as an important prognostic factor for the development of heart failure (Pfeffer and Braunwald, 1990). As described in chapter 1, remodeling of the non-infarcted myocardium includes morphological, biochemical and electrophysiological changes in the cardiomyocyte, as well as changes in the connective tissue extracellular matrix.

The renin-angiotensin system (RAS) is activated after a myocardial infarction (Remme, 1986). The contribution of the RAS to the structural changes described in the previous chapter are incompletely known. ACE inhibitors have been shown to reduce the mortality of congestive heart failure (which was, amongst others, due to myocardial infarction) in humans (Consensus Trial Study Group, 1987) and rats after MI (Pfeffer, 1985, 1987). The latter author also showed that prolonged captopril treatment reduced ventricular dilatation after $\mathrm{MI}$ in the rat, and suggested that the two phenomena may be interrelated (Pfeffer and Braunwald, 1990).

Schoemaker et al. (1991) found that the delayed administration of captopril (started at 21 days after infarction) improves cardiac function in rats. In contrast, administration of captopril started immediately after infarct induction in the rat (early treatment) did not augment but rather attenuated cardiac function. Assuming that cardiac structure and function are interrelated, this suggests that different timing of captopril treatment might also exert different effects on cardiac remodeling after $\mathrm{Ml}$. 
We studied the effects of early and delayed captopril treatment on cardiac remodeling after Ml. We focussed on left ventricular wall area and cardiomyocyte volume, parameters which reflect myocardial hypertrophy, and ventricular dilatation. The effects of captoprill were compared with those of the vasodilator hydralazine to account for the blood pressure reducing effects of captopril.

\subsection{EXPERIMENTAL PROTOCOLS}

\subsubsection{Animals}

Adult male Wistar rats (body weight $314 \pm 17 \mathrm{~g}$ ) were used. Non-treated sham operated $(n=4)$ or infarct animals $(n=8)$ served as controls. Infarct animals were either treated with the angiotensin I converting enzyme inhibitor captopril $(n=8-9)$ or hydralazine $(n=5-8)$ during the first 3 weeks (early treatment) or during the 4 th and 5th week (delayed treatment) after induction of the myocardial infarction (Ml). Surgery was performed as described in chapter 2.

\subsubsection{Treatment}

Captopril and hydralazine were administered wia subcutaneous osmotic minipumps (ALZET, 2001). The infusion rates were $500 \mu \mathrm{g} \mathrm{kg}$ " $\mathrm{hr}^{-1}$ for captopril and 3 $\mathrm{mg} \mathrm{kg}{ }^{-1}$ day $^{-1}$ for hydralazine.

Tissue processing, morphometry, histochemistry to visualize collagen and morphometry to determine the collagen positive area are described in chapter 2.

Captopril and hydralazine treated infarct animals were compared with non-treated infarct animals from a previous experiment (chapter 3). 


\subsection{RESULTS}

\subsubsection{Infarct size}

Infarct sizes in the groups ranged from $32 \pm 8 \%$ to $43 \pm 11 \%$ (means $\pm S D$ ); there were no statistical differences between untreated and treated groups.

\subsubsection{Effects on heart weight index}

Heart weight index was increased in $\mathrm{Ml}$ animals at day 21. The heart weight relative to body weight was decreased by early treatment with both captoprill $(0.29 \pm 0.01$ $\left.\mathrm{g} \cdot 100 \mathrm{~g}^{-1}\right)$ and hydralazine $\left(0.28 \pm 0.01 \mathrm{~g} \cdot 100 \mathrm{~g}^{-4}\right)$, compared to non-treated MI animals $\left(0.36 \pm 0.02 \mathrm{~g} \cdot 100 \mathrm{~g}^{-1} ; \mathrm{FIG}\right.$. 1). This parameter was not increased in nontreated MI animals at day 35. Delayed treatment had no effect.

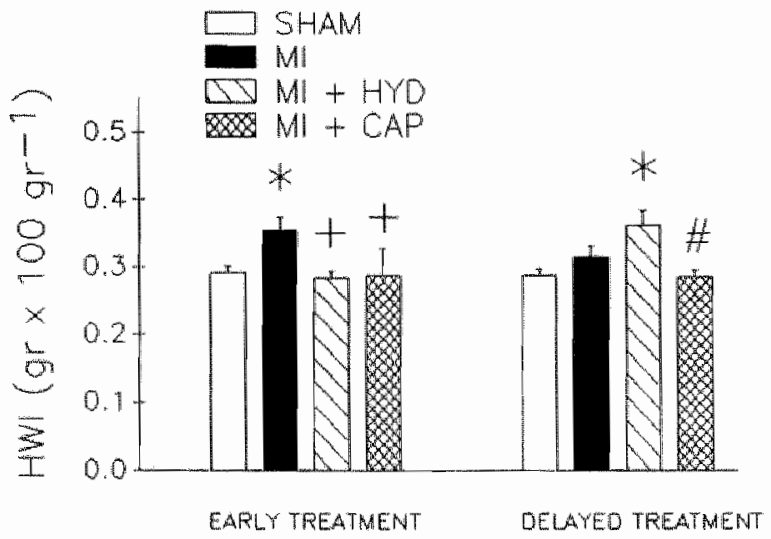

FIG. $1 ;$ HEAFT WEIGHT CORRECTED FOR BODY WEIGHT (HWI); effects of early and delayed captoprit or hydralazine treatment afer Ml * $p<0.05$; Ml versus sham, $+p<0.05$; Captopril and hydralazine wersus nontrated MI. \# p<0.05, Captopril versus hydralazine treated MI. 


\subsubsection{Effects on left ventricular wall area}

The left ventricular wall area was not changed in Ml animals at day 21 (Sham: 47.8 \pm 2.8 ; Ml: $52.8 \pm 2.8 \mathrm{~mm}^{2}$; FIG. 2). Early captopril treatment had no effect (45.0 \pm $\left.2.3 \mathrm{~mm}^{2}\right)$, while the left ventricular wall area was increased $(65.7 \pm 2.4 \mathrm{~mm}$ ) in hydralazine treated animals.

At day 35, left ventricular wall area in MI animals was not different from that in sham animals. Delayed treatment with either captopril or hydralazine had no effect as. compared to untreated rats, although the effects of captopril and hydralazine were significantly different (FIG. 2).

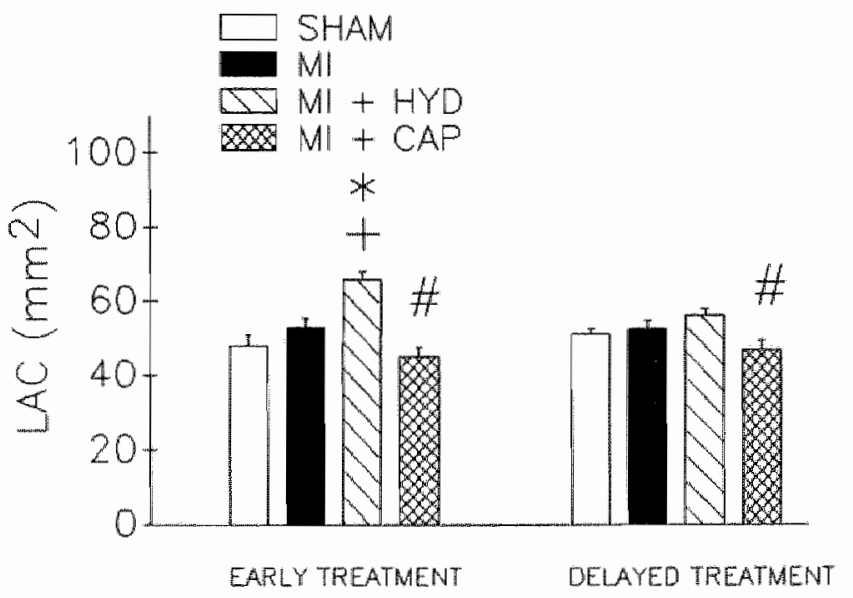

FIG. 2; LEFT VENTRICULAR WALL AREA (LAC); effects of early and delayed captopril or hydralazine treatment atter M. $p<0.05 ;$ MI versus sham $+p<0.05 ;$ Hydralazine versus nori-treated Ml, \# p<0.05; Captopril versus hydralazine treated MI. 


\subsubsection{Effects on left ventricular inner circumference}

Left ventricular inner circumference had not changed in Ml animals at day 21 (FIG. 3). Early treatment with neither captopril nor hydralazine affected this parameter.

At day 35, the left ventricular inner circumference had increased in Ml animals. Delayed treatment with neither captopril nor hydralazine affected the inner circumference of the left ventricle, which was increased by MI.

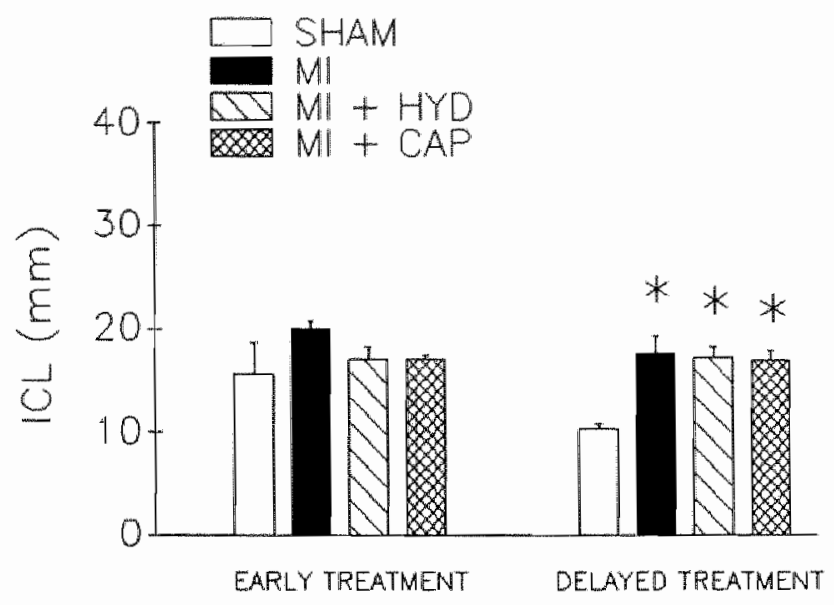

FIG. 3; LEFT VENTRICULAR INNER CIRCUMFERENCE (ICL); effects of early and delayed captopril or hydralazine treatment after MI * $\mathrm{p}<0.05$; Captopril, hydralazine and non-treated Mi versus sham. 


\subsubsection{Effects on left ventricular cardiomyocyte volume}

Left ventricular cardiomyocyte volume had increased at day 21 in Ml animals (FIG.

4). Early captopril treatment reduced the cardiomyocyte volume, while hydralazine had no effect.

At day 35, cardiomyocyte volume in $\mathrm{Ml}$ animals was not different from that in sham animals (MI: $34.9 \pm 2.3$; sham: $31.9 \pm 2.1 \mu \mathrm{m}^{3} \cdot 10^{3}$ ). Delayed treatment with both captopril $\left(24.1 \pm 2.9 \mu \mathrm{m}^{3} \cdot 10^{3}\right)$ and hydralazine $\left(22.8 \pm 2.0 \mu \mathrm{m}^{3} \cdot 10^{3}\right)$ reduced this parameter.

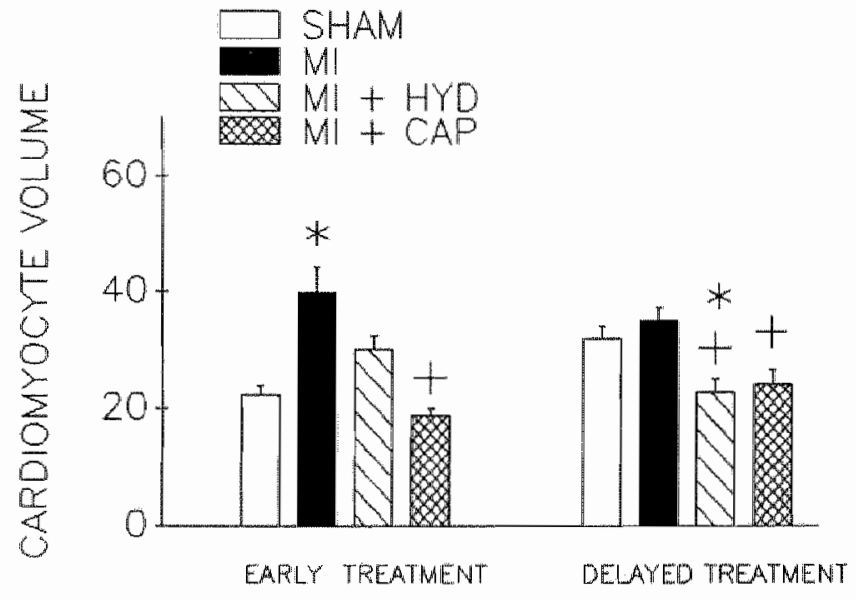

FIG. 4: LEFT VENTRICLILAR CARDIOMYOCYTE WOLUME; effects of early and delayed captoprll or hydralazine treatment after MI. ${ }^{*} p<0.05 ;$ Mi versus sham, $+p<0.05$; Captopril and hydrallazine versus non-traated MI 


\subsection{DISCUSSION}

Our findings regarding structural alterations in the left ventricle after $\mathrm{MI}$, as modulated by pharmacological interventions corroborate those of the previous chapter (chapter 3). Myocardial infarction causes hypertrophy of cardiomyocytes as early as 21 days post ML. This is associated with an increased heart weight at that time, but five weeks after the infarction this phenomenon has dissipated. Dilatation of the left ventricle, measured as inner circumference is not found at day 21 , but is significant at 5 weeks after Ml.

Captopril reduces myocardial hypertrophy, measured as both cardiomyocyte volume and heart weight. At the same time it reduces blood pressure (Schoemaker et al, 1991). To verify the contribution of the blood pressure reduction to the observed effects, the arteriolar vasodilator hydralazine was used. In a previous study (Smits et al, 1991), 3mg/kg · day hydralazine reduced blood pressure in chronically infarcted animals (infarct $90 \pm 5$; hydralazine $82 \pm 3 \mathrm{mmHg}$ ), and at the same time it increased central venous pressure (infarct $0.8 \pm 0.7$; hydralazine 4.1 $\left.\pm 0.9 \mathrm{~cm} \mathrm{H} \mathrm{H}_{2} \mathrm{O}\right)$. The effect on blood pressure $(78 \pm 4 \mathrm{mmHg})$ but not on central venous pressure $\left(0.1 \pm 0.6 \mathrm{~cm} \mathrm{H}_{2} \mathrm{O}\right)$ is similar to that of captopril. In spite of similar effects on arterial blood pressure early after infarction, hydralazine did not affect the hypertrophic response at the level of the cardiomyocytes, and actually increased left ventricular wall area. Late treatment had structural effects that were similar to captopril. These data suggest that the effects of captopril on cardiac structure are exerted mainly during the early phase after infarction, and much less during the late phase.

As was discussed in chapter 1, both the systemic and local (cardiac) 
renin-angiotensin system are activated following myocardial infarction. At this stage, with the present methodology ${ }_{n}$ any effects observed during ACE inhibition cannot be related to either of the two systems. The increased heart weight after MI might include hypertrophic and proliferative responses, as well as edema formation. Conceivably angiotensin II is involved in the formation of hypertrophy and proliferation. Studies in vitro on chick cardiomyocytes have yielded evidence that angioten sin II induces a hypertrophic response, but not a proliferative effect in these cells (Aceto and Baker, 1990). Our finding that captopril reduces myocyte volume after MI fits the hypothesis that angiotensin II is involved in the regulation of this response.

A proliferative cellular response in the myocardium may be induced by angiotensin II in the interstitium. Schelling et al (1979) found a distinct proliferative response to angiotensin II on 3T3 fibroblasts in vitro, which could be inhibited by the angiotensin II antagonist saralasin. The effects of captopril and hydralazine on myocardial interstitial cell proliferation will be discussed in detail in the next chapter.

In the development of edema angiotensin II might also be involved. It induces vasoconstriction, which reduces cardiac perfusion which might sustain edema. Captopril has been shown to have distinct dilatory effects on the coronary circulation of the rat heart (Van Gilst et al, 1988). Improvement of cardiac perfusion may resolve the edema, which occurs in response to myocardial infarction.

In addition to a direct block of angiotensin II mediated effects, the response to captopril may depend upon several other effects. Cohn et al (1986) demonstrated the favorable effects of combined veno-and arteriolar dilator therapy on mortality in congestive heart failure. Determination of the effects of therapy on 
mortality in congestive heart failure was not the aim of our studies. Our results on the effects of hydralazine on the structural alterations in the left ventricular myocardium after a myocardial infarction leads to the conclusion that the blood pressure lowering response does not play a crucial role. One prominently possible mediator of a hypertrophic effect may be the sympathetic nervous system. Since angiotensin Il has clear stimulatory effects on the central component of this system and concomitantly facilitates norepinephrine release from peripheral nerve terminals (Zimmerman et al, 1984), reduction of angiotensin $\|$ may result in reduction of sympathetic nerve activity. Resultant inhibition of a-adrenoceptor (Simpson, 1985) or $\beta$-adrenoceptor stimulation (Schwartz, K., personal communication) may then inhibit hypertrophy. In this respect, it is important to note that hydralazine has been shown to have distinct sympathetic stimulatory effects, as indicated by an increased turnover of norepinephrine in the heart of normotensive and hypertensive rats (Tsoporis and Leenen, 1988). Although cardiomyocyte volume did not further increase during hydralazine treatment, wall area, another indicator for hypertrophy, did increase. Thus, at this point we cannot exclude a mediating role for the sympathetic nervous system.

The angiotensin I-converting enzyme (ACE) serves multiple systems. It is involved in conversion of angiotensin I, but also in bradykinin metabolism (Yang et al, 1970). As a consequence, inhibition of ACE will result in increased bradykinin levels. Although bradykinin is not known to generate hypertrophy, it is recognized as a mitogen in human cultured fibroblasts (Owen and Villereal, 1983). In a recent study, however, a bradykinin-2 receptor antagonist annihilated the limiting effect of ramiprilate on infarct size following acute infarction in dog hearts (Martorana et all, 
1990). Limitation of infarct size would be a very effective way to diminish cardiac remodeling (Pfeffer and Braunwald, 1990). Our studies were not directly aimed at comparing infarct size in treated and untreated animals but the available data indicate that the infarct size in treated and non-treated rats is not different. Nevertheless, a bradykinin effect on cardiac remodeling cannot be dismissed with certainty.

Finally, effects unrelated to ACE-inhibition may be considered. Captopril has been suggested to exert a cardioprotective effect by scavenging of free radicals. This has been the subject of an extensive recent review (De Graeff, 1989), in which it was concluded that this effect may be of particular importance during reperfusion of ischemic myocardium. The methods we employed to induce infarcts does, however, exclude reperfusion, rendering this possibility less likely. The present study does not allow conclusions on the detrimental or beneficiall nature of early versus late captopril treatment. In a separate study, Schoemaker and co-workers noted that early captopril treatment results in deterioration of cardiac function. whereas late treatment improves it (Schoemaker et al 1991 ). Early hydralazine treatment does not affect the cardiac function curve (Smits et al, 1991). This suggests that the early cardiomyocyte hypertrophy may contribute to maintenance of cardiac function following infarction.

In concluision, this study clearly indicates that captopril interferes with the early structural response following myocardial infarction. Although we can exclude that a decreased blood pressure mediates this effect, it is not clear at this stage, whether or not and if so how it may be the result of inhilbition of angiotensin II formation. lin chapter 6 this subject will be further addressed experimentally. 


\section{REFERENCES}

Aceto, J.F., Baker, K.M. [Sar']angiotensin II receptor-mediated stimulation of protein synthesis in chick heart cells. Am J Physiol 258, H806-H813 (1990).

Cohn, J.N., Archibald, D.G. Zieche, S., Franciosa, J.S., Harston, W.E., Tristani, F.E., Dunkman, W.B., Jacobs, W., Francis, G.S., Flohr, K.H., Goldman, S., Cobb, F.R., Shah, P.M., Saunders, R., Fletcher, R.D., Loeb, H.S., Hughes, V.C., Baker, B. Effect of vasodilator therapy on mortality in chronic congestive heart failure. New Eng $J$ Med 314, 1547-1552 (1986).

Consensus Trial Study Group. Effects of enalapril on mortality in severe congestive heart failure. Results of the cooperative North Scandinavian enalapril survival study (Consensus). N Eng J Med 316, 1429-1435 (1987).

de Graeff, P.A. Effects of captopril on the heart. Mechanisms and therapeutic potentials. PhD thesis, Groningen, The Netherlands, (1989).

Martorana, P.A., Kettenbach, B., Breipohl, G.. Linz, W. Schölkens, B.A. Reduction of infarct size by local angiotensin-converting enzyme inhibition is abolished by a bradykinin antagonist. Eur J Pharmacol 182, 395-396 (1990).

Owen, N.E., Villereal, M.L. Lys-bradykinin stimulates $\mathrm{Na}^{*}$ influx and DNA synthesis in cultured human fibroblasts. Cell $32,979-985$ (1983).

Pfeffer, M.A., Pfeffer, J.M., Steinburg, C., Finn, P. Survival after an experimental myocardial infarction: beneficial effects of long-term therapy with captopril. Circulation 72 , 406-412 (1985).

Pfeffer, J.M., Pfeffer, M.A., Braunwald, E. Hemodynamic benefits and prolonged survival with long-term captopril therapy in rats with myocardial infarction and heart failure. Circulation 75(suppl I), 149-155 (1987).

Pfeffer, M.A., Braunwald, E. Ventricular remodeling after myocardial infarction. Circ Res 81, 1161-1172 (1990).

Schelling, P., Ganten, D., Speck, G., Fischer, H. Effects of angiotensin II and angiotensin II antagonist saralasin on cell growth and renin in 3T3 and SV3T3 cells. J Cell Physiol 98, 503-514 (1979).

Schoemaker, R.G., Debets, J.J.M., Struyker-Boudier, H.A.J., Smits, J.F.M. Delayed but not immediate therapy improves cardiac function in conscious rats, following myocardial infarction. In press, 1991.

Simpson, P. Stimulation of hypertrophy of cultered neonatal rat heart cells through an alpha,-adrenergic receptor and induction of beating through an alpha $\mathrm{i}^{-}$and beta, adrenergic receptor interaction. Circ Res 56, 884-894 (1985). 
Smits, J.J.M., Cleutjens, J.P.M. Van Krimpen, C., Schoemaker, R.G."Daemen, M.J.A.P. Cardiac remodeling in hypertension and folowing myocardial infarction: effects of arteriolar vasodilators. Basic Res Cardiol 86(suppl 1), 133-139 (1991).

Tsoporis, J., Leenen. F.H.H. Effects of arterial vasodilators on cardiac hypertrophy and sympathetic activity in rats. Hypertension 11, 376-386 (1988).

Van Gilst, W.H., Scholtens, E., de Graeff, P.A., de Langen, C.D.J., Wesseling, H. Differential influences of angiotensin converting-enzyme inhibitors on the coronary circulation. Circulation 77 (suppl I), I-24-I-29 (1988).

Yang, H.Y.T., Erdoes, E.G., Levin, Y. A dipeptill carboxypeptidase that converts angiotensin I and inactivates bradykinin. Biochem Biophys Acta 214, 374-376 (1970).

Zimmerman, B.G., Sybetz E.J., Wong, P.C. Interaction between sympathetic and renin-angiotensin system. J Hypert 2, 581-587 (1984). 



\section{CHAPTER 5}

EFFECTS OF EARLY AND DELAYED CAPTOPRIL TREATMENT ON MYOCARDIAL DNA SYNTHESIS AND COLLAGEN CONTENT AFTER AN EXPERIMENTAL MYOCARDIAL INFARCTION. 


\subsection{INTRODUCTION}

In the previous chapter we have described the effects of ACE inhibition with captopril an the structural alterations of the myocardium after MI. Recent studies in rats have shown that sustained ACE inhibition, started in the second week after infarct induction also reduces left and right ventricular collagen content (Michel et al, 1988). This observation suggests that the renin-angiotensin system is involved in myocardial collagen synthesis after MI. Long term ACE inhibition augments cardiac function in rats after MI (Pfeffer et al, 1987). Recent data from Schoemaker et al (1991) indicate that ACE inhibition during the first three weeks after Ml, however, appears to further attenuate the already impaired cardiac function. This suggests that timing of the therapy is important. Early captopril treatment (chapter 4) reduced the volume of left ventricular cardiamyocytes, while delayed treatment had no effects. In this chapter we describe the effects of early and delayed ACE inhibition on DNA synthesis and collagen content of the non-infarcted left and right ventricle.

\subsection{EXPERIMENTAL PROTOCOLS}

Adult male Wistar rats with a body weight of $326 \pm 31 \mathrm{~g}$ were used.

All experiments were performed according to institutional guidelines. 


\subsubsection{Captopril treatment}

The early treatment group included sham operated animals $(n=4)$ and infarct animals $(n=8-10)$ treated for 7,14 or 21 days. The delayed treatment group included sham $(n=4)$ and infarct animals $(n=8-10)$, treated from day 21 until day 35. Captopril was administered via osmotic mini-pumps at an infusion rate of 500 $\mu \mathrm{g} \mathrm{kg}^{-1} \cdot \mathrm{hr}^{-1}$.

\subsubsection{Hydralazine treatment}

To evaluate the blood pressure lowering effects of captopril, a second series of animals was treated with the vasodilator hydralazine. One group of sham animals was treated with hydralazine during 2 weeks. Three groups of MI animals were treated during the first 2 weeks, the first 3 weeks or during the 4 th and 5 th week after Ml. Hydralazine was also administered via an osmotic mini-pump at an infusion rate of $3 \mathrm{mg} \cdot \mathrm{kg}^{1} \cdot \mathrm{day}^{1}$,

The animal groups treated with captoprill or hydralazine during the first 3 weeks or the 4th and 5th week after MI, were also used for the study, which is described in chapter 4 .

Since the MI induced increase in DNA synthesis is mainly restricted to the first 2 weeks after infarct induction (chapter 3), the effects of captopril and hydralazine on DNA synthesis were only studied in this period. To label DNA synthesizing cells, the animal groups sacrificed 1 or 2 weeks after infarct induction, received BrdU 7 days before termination of the experiment. 
The methods used for the present study including surgery, tissue processing visualization of BrdU labeled nuclei to determine the labeling fraction and determination of the collagen content have been described in chapter 2 .

\subsection{RESULTS}

\subsubsection{Infarct size}

The mean infarct size for all Ml animals was $38 \pm 1 \%$.

\subsubsection{Effects of early treatment on left and right ventricular interstitial DNA} synthesis

In sham-operated animals, captopril did not affect DNA synthesis (FIG. 1A). Captopril significantly inhibited the MI induced increase in labeling in both the left (at 7 and 14 days) and right ventricle (at 14 days). In contrast, hydralazine slightly increased DNA synthesis in the right ventricle of sham-operated rats $(7.4 \pm 0.4 \%$ versus $3.6 \pm 0.6 \%$ in treated and untreated rats, resp.), whereas it was devoid of effects on DNA synthesis in MI rats (FIG. 1B). 


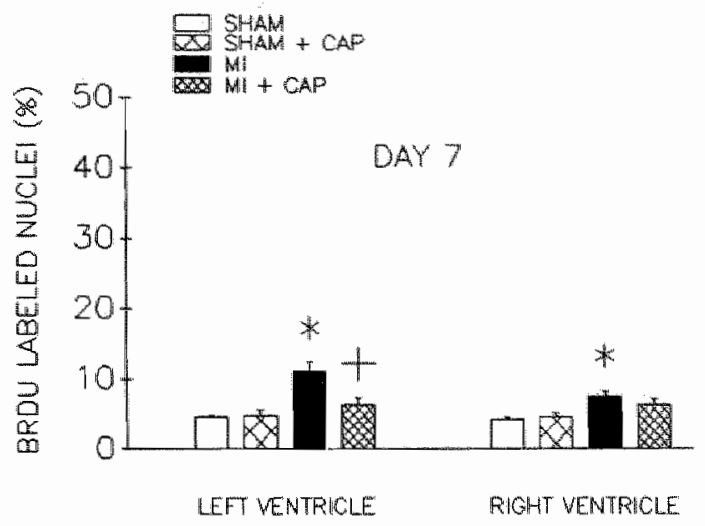

FIG. IA; BRDU LABELING; effects of captoprll treatment during 1 week after MII. ${ }^{*} p<0.05$; MI versus sham, * p,005; Captopril versus non-treated Mi.

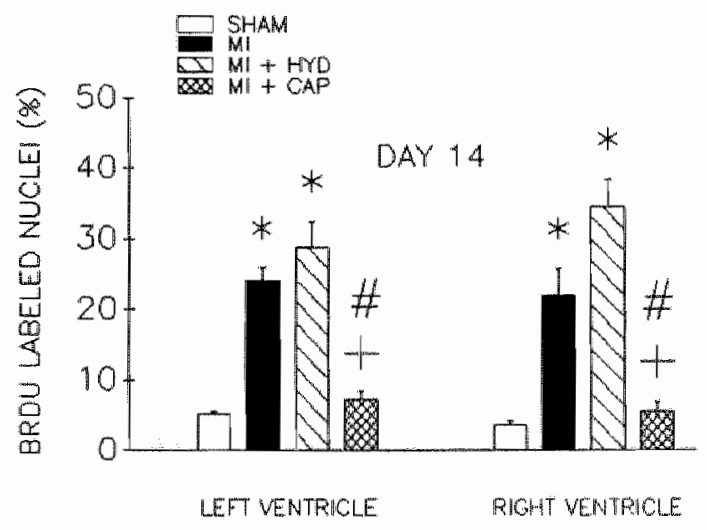

FIG. 1B; BRDU LABELING; effects of captopril and hydralazine treatment during the tirst 2 weeks after MI. * $p<0.05$ : Wil versus sham $+p<0.05$; Captopril versus non-treated Ml, \# $p<0.05$; Captopril versus hindralazine treated MI. 


\subsubsection{Effects of early and delayed treatment on left and right ventricular collagen content}

Early captopril and hydralazine treatment reduced the $\mathrm{Ml}$ induced increase of the collagen content of the right and the non-infarcted left ventricle (FIG. 2).

Delayed treatment with both drugs did not have a statistically significant effect on the MI induced increase in collagen content of both ventricles, although collagen content in the treated groups was not different from shams (F/G. 2).

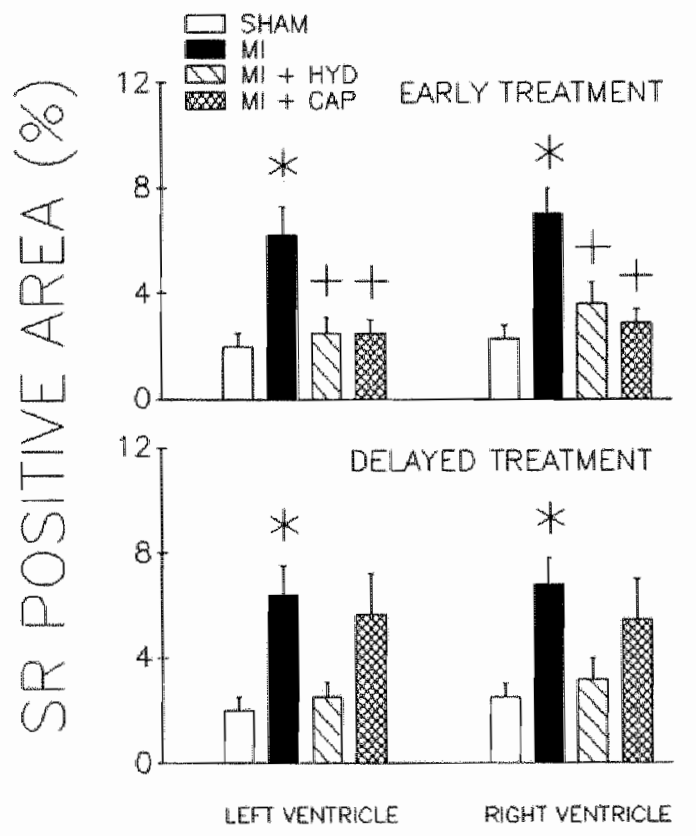

FIG. 2; SIRIUS RED (SA) POSITIVE AREA; Eftects of early and delayed captopril and hydralazine treatment atter MI. $p<0.05$; Ml versus sham, + $0<0.05$; Captopril and hyclalazine versus nonmreated MI. 


\subsection{DISCUSSION}

This study shows that captopril treatment early after infarct induction reduces the MI induced DNA synthesis. Early but not delayed captopril treatment reduced the increase in collagen content in the non-infarcted myocardium. Early hydralazine treatment only affected the collagen content, but had no effects on DNA synthesis.

Several mechanisms may be considered for the effect of captopril on myocardial DNA synthesis. First of all, reduction of cell proliferation by captopril could be a secondary phenomenon due to a decreased afterload. Early hydralazine treatment resulted in a similar reduction of the blood pressure, but did not reduce the increase in DNA synthesis. Therefore it seems unlikely that the effects of early captopril treatment on DNA synthesis are due to the effects of captopril on blood pressure (Schoemaker et al, 1991).

Secondly, bradykinin may be involved. The angiotensin I converting enzyme (ACE) is involved in the bradykinin metabolism and ACE inhibition increases bradykinin levels (Skeggs et al ${ }_{0}$ 1956). However, bradykinin is mitogenic for human fibroblasts in vitro (Owen and Villereal, 1983) and it therefore seems unlikely that this peptide would reduce the myocardial proliferative response of the non-infarcted left and right ventricular wall.

Alternatively, the effect of captopril on myocardial DNA synthesis may depend on reduced circulating angiotensin II levels. Circulating angiotensin II may enhance endothelial permeability of small coronary arteries, allowing mitogens to gain access to the interstitium (Weber et al, 1989). One of these mitogens might in fact be angiotensin $\|$ itself, since angiotensin $\|$ is a mitogen for cultured 3T3 fibroblasts (Schelling et al, 1979) and vascular smooth muscle ceils in vivo 
(Daemen et al, 1991). Also, ACE inhibition has been shown to inhibit neointima thickening following vascular injury (Powell et al, 1989).

Our observations suggest that myocardial DNA synthesis early after Mil is regulated independent from myocardial collagen synthesis, since early captopril and hydralazine treatment both reduced the collagen content, while DNA synthesis was only reduced by captopril. This is also supported by recent observations in our laboratory (Cleutjens, personal communication), which indicate that collagen I mRNA is predominantly expressed in cells which do not synthesize DNA following MI. The discrepancy between DNA-synthesis and collagen-synthesis suggests, that in the acute phase of myocardial infarction collagen-synthesis is restricted to resident fibroblasts. The off-spring of these cells may, after maturation, contribute to collagen synthesis. We suggest that collagen deposition after MI might be regulated by ventricular wall tension. DNA synthesis, however, might be induced by angiotensin II.

Our data also indicate that, once collagen is formed, the myocardial collagen content cannot be reduced by a 2 week period of afterload reduction. It has been shown that synthesis of collagen is followed by intense crosslinking (Blumenfeld and Seifter, 1990). This suggests that ventricular wall tension alterations only affect immature, but not mature, collagen.

In conclusion , different mechanisms seem to be involved in myacardial DNA and collagen synthesis after MI. DNA synthesis seems to be dependent on angiotensin 11 , whereas the myocardial collagen content might depend primarily on ventricular wall tension. This will be discussed in greater detail in chapter 7 . 


\section{REFERENCES}

Blumenfeld, O.O., Seifter, S. Biochemistry of connective tissue with special emphasis on the heart. Robinson, T.F., Kinne, R.K.H. (eds.): Cardiomyocyt-connective tissue interactions in health and disease. Issues biomed. Basel, Karger 13, 5-36 (1990).

Daemen, M.J.A.P., Lombardi, D.M., Bosman, F.T., Schwartz, S.M. Angiotensin II induces smooth muscle cell proliferation in the normal and injured rat arterial wall. Circ Res 68 (1991).

Michel, J.B., Lattion, A.L., Salzmann, J.L., de Lourdes Cerol, M., Phillppe, M., Camilleri, J.P., Corvol, P. Hormonal and cardiac effects of converting enzyme inhibition in rat myocardial infarction. Circ Res 62, 641-650 (1988).

Owen, N.E., Villereal, M.L. Lys-bradykinin stimulates $\mathrm{Na}^{+}$influx and DNA synthesis in cultured human fibroblasts. Cell 32, 979-985 (1983).

Pfeffer, J.M., Pfeffer, M.A., Braunwald, E.: Hemodynamic benefits and prolonged survival with long-term captopril therapy in rats with myocardial infarction and heart failure. Circulation 75(suppl I), 149-155 (1987).

Powell, J.S., Clozel, J.P., Müller, R.K.M., Kuhn, H., Hefti, F., Hosang, M., Baumgartner, H.R. Inhibitors of angiotensin-converting enzyme prevent myointimal proliferation after vascular injury. Science 245, 186-188 (1989).

Schelling, P., Ganten, D., Speck, G., Fischer, H. Effects of angiotensin II and angiotensin II antagonist salarasin on cell growth and renin in 3T3 and SV3T3 cells. J Cell Physiol 98, 503-514 (1979).

Schoemaker, R.G., Debets, J.J.M., Struyker-Boudier, H.A.J., Smits, J.F.M. Delayed but not immediate therapy improves cardiac function in conscious rats, following myocardial infarction. In press (1991)

Skeggs, L.T., Kahn, J.R., Shumway, N.P. The preparation and function of the hypertensin-converting enzyme. J Exp Med 103, 295-299 (1956).

Weber, K.T., Pick . R., Jalil, J.E., Janicki, J.S., Carroll, E.P. Patterns of myocardial fibrosis. J Mol Cell Cardiol 21 (suppl V). 121-131 (1989). 

CHAPTER 6

EFFECTS OF EARLY TREATMENT WITH THE ANGIOTENSIN \|-1 RECEPTOR ANTAGONIST DUP 753 ON THE STRUCTURAL ALTERATIONS IN THE RAT HEART AFTER MYOCARDIAL INFARCTION. 


\subsection{INTRODUCTION}

In the previous chapters it was shown that early treatment with the angiotensin I converting enzyme inhibitor captopril reduces ventricular wall area and ventricular dilatation, cardiomyocyte volume, the increase in interstitial DNA synthesis and collagen content after MI.

Assuming that the captopril effects are due to interference with the systemic and/or local (cardiac) (Re, 1987; Dzau, 1987) renin angiotensin system, the question arises as to how the components of the renin angiotensin system modulate cardiac remodeling after MI. If the captopril effect is due to inhibition of the production of All, blocking of the All receptors should have an effect similar to inhibition of the angiotensin I converting enzyme. To test this hypothesis we studied the effects of early administration of the recently described selective non-peptide All-1 receptor antagonist DuP 753 (Chiu et al, 1989) in the first two weeks after Ml on left ventricular wall area, dilatation, cardiomyocyte volume, interstitial DNA synthesis and collagen content in the non-infarcted myocardium.

Some data presented in this chapter, concerning captopril treated animals, have also been shown in the chapters 4 and 5 .

\subsection{EXPERIMENTAL PROTOCOLS}

\subsubsection{Animals}

Aduit male Wistar rats with a body weight of $326 \pm 29 \mathrm{~g}$ were used. Groups of sham operated $(n=4)$ or infarct animals were either treated $(n=7-9)$ with the angiotensin II antagonist DuP 753 for 14 days or were not treated $(n=8-10)$. 


\subsubsection{Treatment}

DuP 753 was administered via osmotic mini-pumps at an infusion rate of

$15 \mathrm{mg} \mathrm{kg}^{-1}$ day". To label DNA synthesizing cells, all animals received BrdU, starting 7 days before they were sacrificed.

The methods used for the present study including surgery, tissue processing, morphometry, visualization of BrdU labeled nuclei, determination of the BrdU labeling fraction, histochemistry to visualize collagen and morphometry to determine the collagen positive area, have been described in chapter 2 .

Data on interstitial DNA synthesis and collagen content of DuP 753 treated infarct and sham animals were compared with previously described data obtained in nontreated and captopril treated infarct and sham animals (chapter 5).

\subsection{RESULTS}

\subsubsection{Effects on left ventricular wall area and inner circumference}

Since the starting body weights of DuP 753 animals were lower than the body weights of non-treated MI and sham animals, data on ventricular wall area (LAC) were corrected for body weight (LAIC).

Neither DuP 753 nor captopril had any effect on left ventricular wall area or dilatation in MI (FIGS. 1A and B) or sham animals (data not shown). 

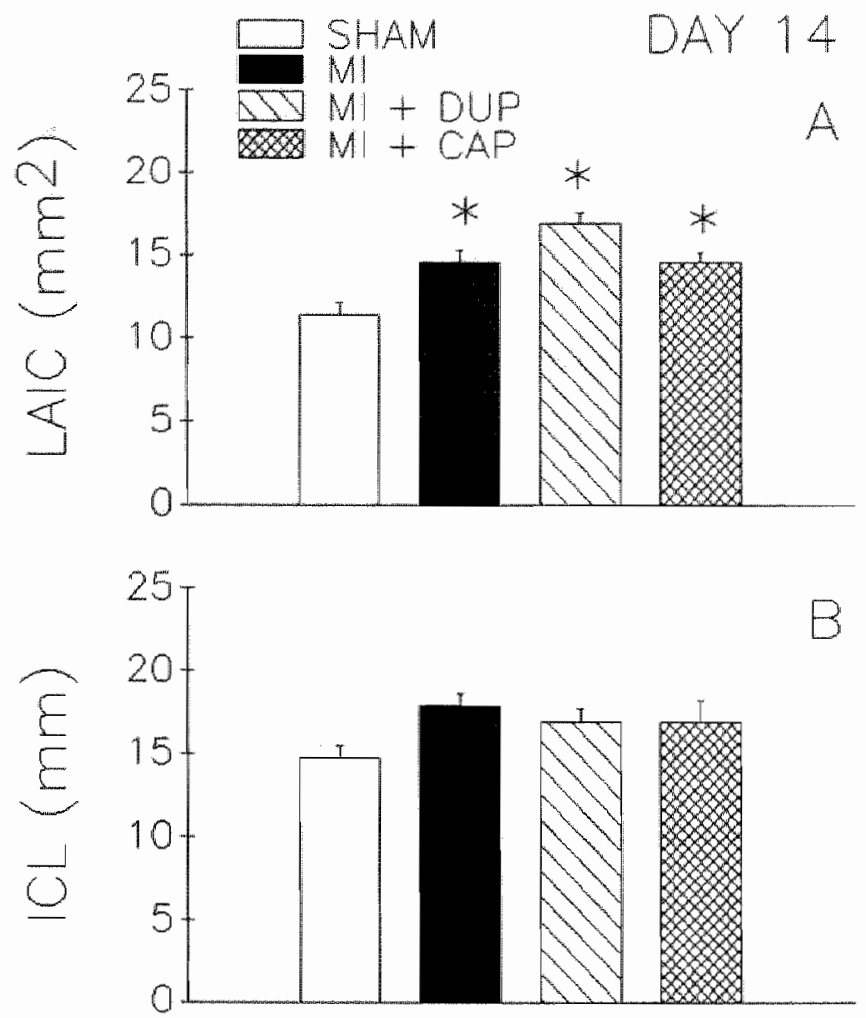

FIGS. IA and B; LEFT VENTRICULAFI WALL AREA CORRECTED FOR BODY WEIGHT AND INFARCT SIZE (LAIC) and LEFT VENTRICULAR INNER CIRCUMFERENCE (ICL); effects of CAP and DuP 753 treatment during 2 woeks after MI. " $p<0.05$; non-treated Ml captopril or hydraiazine treated MI versus sham. 


\subsubsection{Effects on left ventricular cardiomyocyte volume}

Two weeks of DuP 753 treatment reduced the $\mathrm{Ml}$ induced increase in cardiomyocyte volume (Table 1). Both DuP 753 and captopril also reduced this parameter in sham animals. However, the cardiomyocyte volume of DuP 753 treated Ml animals was significantly increased as compared to untreated sham animals. Captopril reduced the cardiomyocyte volume of MI animals to a lower level than DuP 753.

Table 1

\section{LEFT VENTRICLE DAY 14}

Cardiomyocyte volume $\left(\mu \mathrm{m}^{3} \cdot 10^{3}\right)$

Sham

$$
17.1 \pm 1.7
$$

$(n=4)$

Sham + DuP

$(n=4)$

$\begin{array}{ll}\begin{array}{l}\text { Sham + CAP } \\ (n=4)\end{array} & 7.4 \pm 0.4^{*} \\ \begin{array}{l}\text { MIl } \\ (n=6)\end{array} & 36.0 \pm 1.7^{*} \\ \begin{array}{l}\text { MI + DuP } \\ (n=6)\end{array} & 24.2 \pm 2.2^{\star *} \\ \begin{array}{l}\text { Ml }+ \text { CAP } \\ (n=6)\end{array} & 10.7 \pm 0.5^{* *}\end{array}$

Cardiomyocyte volume of the left ventricle; effects of 2 weeks DuP 753 and captoptil traatment

* $p<0.05$, DuP 753 or CAP treated sham and DuP 753 treated or non-treated Mi versus sham.

$+p<0.05$, DUP 753 or CAP reated MI wersus non-treated MI.

* $p<0.05$, CAP treated MI versus DuP 753 treated MU. 


\subsubsection{Effects on left ventricular interstitial DNA synthesis}

DuP 753 did not affect DNA synthesis in the left ventricle of sham animals (data not shown), but reduced the MI induced increase in DNA synthesis (FIG. 2). However, the labeling fraction of DuP 753 treated MI animals was significantly increased as compared to untreated sham animals.

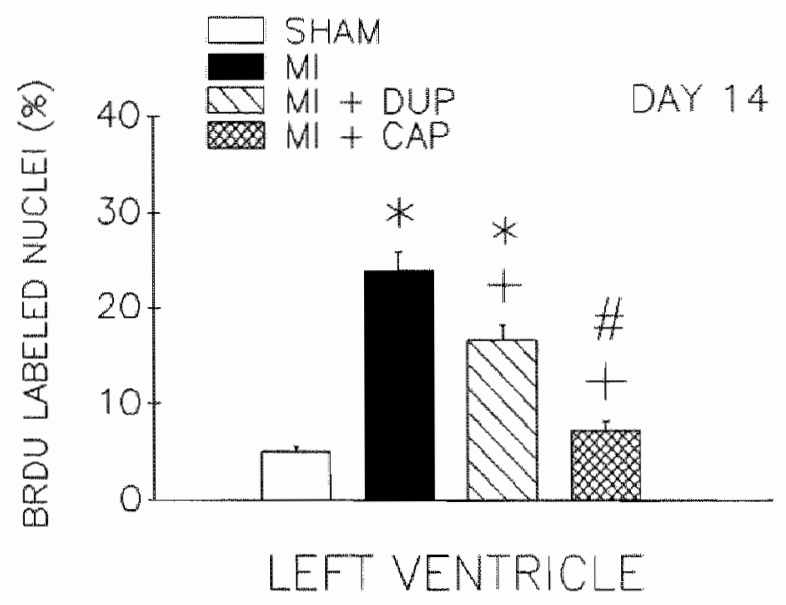

FIG. 2; Left ventricular BRDU LABELING FRACTION (\%); effects of DUP 753 and CAP treatment during two woeks after MI. " $p<0.05$; MI versus sham $+p<0.05$; captopril or DuP 753 versus Ml, $p<0.05$; captopril versus DuP 753 . 


\subsubsection{Effects on left ventricular collagen content}

DuP 753 did not affect the collagen content of the left ventricle of sham animals (data not shown), but reduced the amount of collagen in the non-infarcted part of the left ventricle (FIG. 3). This is reflected in a reduction of the sirius red (collagen) positive area.

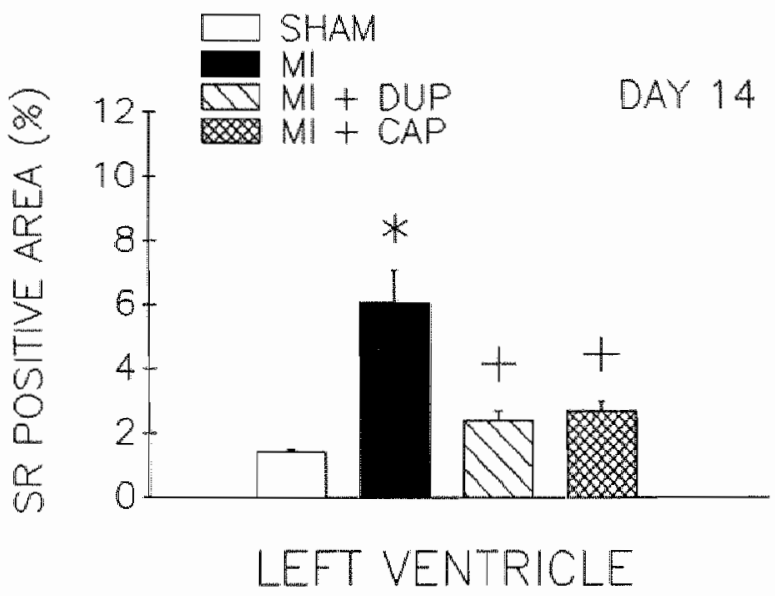

FIG. 3; SIRIUS RED POSITVE AREA of the left ventricle: effects of DuP 753 and CAP treatment diring two weeks after MH. " $p<0.05$; MI versus Sham, + p<0.05; DuP 753 or captopril versus non-treated MI.

\subsection{DISCUSSION}

In recent ligand-binding studies two distinct angiotensin II binding-sites were discovered and named All-1 and All-2 (Chiu et al, 1989). The All-1 binding site is specifically involved, amongst others, in the vasoconstrictor response to All (Chiu et al, 1990). 
Although the All-1 binding site has been localized in the rat adrenal cortex and vascular smooth muscle cells, it is not known whether it is also present in the rat heart. The All-2 binding site is present in adrenal medulla and uterus, but is not linked to any known second messenger system and is not involved in known physiological responses. Timmermans and coworkers recently developed several non-peptide All receptor antagonists with different affinity to the two All receptor binding sites (Wong et al, 1990). One of these, DuP 753, has a 100-1000 fold greater affinity for the All-1 binding site than for the All-2 site.

The present study was performed to investigate the involvement of the All-1 receptor in the development of structural alterations in the rat heart after Ml. The dose of DuP 753 that was chosen yields a similar effect on blood pressure as captopril in an earlier study (chapter 4 and 5). The inhibition of the All pressor response (a 35-fold rightward shift of the dose response curve (Smits et al, submitted for publication) was comparable to the 17-fold shift of the Al pressor response in studies with captopril (Schoemaker, 1989, Schoemaker et al, 1991).

Neither DuP 753 nor captopril had any effect on left ventricular wall area or left ventricular inner circumference. Furthermore, both drugs reduced the left ventricular cardiomyocyte volume. However, only in MI animals treated with DuP 753 , this parameter was still increased, when compared to sham animals. Both drugs also reduced the MI induced increase in DNA synthesis and the interstitial collagen content. DNA synthesis in captopril treated Ml animals was reduced to sham levels, while DNA synthesis in DuP $753 \mathrm{MI}$ animals was still increased, when compared to sham animals. 
Several explanations for the apparent discrepancy in the effects of both drugs on cardiomyocyte volume and interstitial DNA synthesis have to be considered. First of all, a DuP 753 effect on blood pressure has to be considered. This is, however, unlikely since ACE inhibition with captopril and specific blockade of the All:1 receptor with DuP 753 both lower arterial blood pressure to a similar extent (Schoemaker et al, 1991; Smits et al, submitted for publication). Bload pressure mediated effects on cardiomyocyte volume and myocardial DNA synthesis during All-1 receptor blockade with DuP 753 is also unlikely because treatment with hydralazine does not affect these parameters (chapters 4 and 5).

Secondly, the effects of All could be mediated through the All-2 binding site. DuP 753 has a 100-1000 fold greater affinity for the All-1 binding site than for the All-2 binding site (Wong et al, 1990), which implies that with the chosen dose there is very little blockade of the All-2 binding site. Furthermore, the All-2 binding site is not linked to any known second messenger system and is not involved in any known physiological response. The lack of knowledge about this binding site, however, precludes a firm conclusion regarding possible involvement of All-2 binding sites.

Alternatively "the effect of angiotensin II may depend upon interaction with a receptor to which DuP 753 does not have access. In this regard, the binding site on chromaffine threads in the cellular nuclei has to be considered (Dzau, 1987; Re, 1987). Given the polar structure of DuP 753 this is a plausible explanation of the lack of effect of DuP 753 in this study. 
Finally, the ACE inhibitory effects of captopril might not only be mediated by the All receptor system. An alternative possibility is an increased bradykinin plasma concentration, since ACE inhibitors also inhibit the breakdown of bradykinin (Yang et al, 1970). This possibility is supported by the observation that DuP 753 lacks bradykinin-potentiating effects in vivo (Wong et al, 1990). Martorana et al (1990) described in a canine coronary artery ligation model that the infarct-limiting effects of the ACE inhibitor ramiprilat were abolished by a bradykinin antagonist. Thus our findings with captopril may be related to interierence with bradykinin.

Our data suggest that the collagen deposition in the myocardial interstitium after MI is generated by afterload, since DuP 753 , captopril and hydralazine all reduce blood pressure and collagen content to the same extent.

In conclusion, our data indicate that the effects of ACE inhibition on cardiac remodeling following myocardial infarction in rats are only partly mediated by All/All-1 receptor interaction. Alternative mechanisms have to be considered, including mediation of cardiac remodeling by bradykinin or All-2 receptor interaction. This will the subject of future studies. 


\section{REFERENCES}

Chiu, A.T., Herblin, W.F., McCall, D.E., Ardecky, R.J., Carini, D.J., Duncia, J.V., Pease, L.J., Wong, P.C., Wexler, R.R., Johnson, A.L., Timmermans, P.B.M.W.M. Identification of angiotensin II receptor subtypes. Biochem Biophys Res Commun $165,196-203$ (1989).

Chiu, A.T., McCall, D.E., Price, W.A., Wong, P.C. Carini, D.J., Duncia, J.V., Wexler, R.R., Yoo, S.E., Johnson, A.L., Timmermans, P.B.M.W.M. Nonpeptide angiotensin II receptor antagonists. VII. Cellular and biochemical pharmacology of DuP 753 , an orally active antihypertensive agent. J Pharmacol Exp Ther 252, 711-718 (1990).

Dzau, $\mathrm{V} . \mathrm{J}$. Implications of local angiotensin production in cardiovascular physiology and pharmacology. Am J Cardiol 59, 59A-65A (1987).

Martorana, P.A., Kettenbach, B., Breipohl, G., Linz, W., Schölkens, B.A. Reduction of infarct size by local angiotensin-converting enzyme inhibition is abolished by a bradykinin antagonist. Eur J Pharmacol 182, 395-396 (1990).

$\mathrm{Re}, \mathrm{R}$. The myocardial intracellular renin-angiotensin system. Am J Cardiol 59, 56A58 A (1987).

Schoemaker, R.G. Experimental heart failure in rats: hemodynamic studies on pathophysiology and therapy. Thesis Maastricht, (1989), ISBN 90-5291-013-8.

Schoemaker, R.G., Debets, J.J.M., Struyker-Boudier, H.A.J., Smits, J.F.M. Delayed but not immediate therapy improves cardiac function in conscious rats, following myocardial infarction. In press (1991).

Smits, J.F.M., van Krimpen, C., Cleutjens, J.P.M., Schoemaker, R.G., StruykerBoudier, H.A.J., Bosman, F.T., Daemen, M.J.A.P. Angiotensin II receptor blockade following myocardial infarction in rats: hemodynamic and structural effects. Submitted for publication.

Wong, P.C., Price, W.A., Chiu, A.T., Duncia, J.V., Carini, D.J., Wexler, R.R., Johnson, A.L., Timmermans, P.B.M.W.M. Nonpeptide angiotensin II receptor antagonists. VIII. Characterisation of functional antagonism displayed by DuP 753, an orally active antihypertensive agent. J Pharmacol Exp Ther 252, 719-725 (1990).

Yang, H.Y.T., Erdoes, E.G., Levin, Y. A dipeptil carboxypeptidase that converts angiotensin $I$ and inactivates bradykinin. Biochem Biophys Acta 214, 374-376 (1970). 

CHAPTER 7

DISCUSSION 


\subsection{GENERAL}

In the last two decennia ${ }_{n}$ ischemic heart disease has become the prime cause of death in the civilized world. The term "ischemic heart disease" refers to clinical manifestations of coronary atherosclerosis. The ensuing hypoperfusion of the myocardium may present as angina pectoris, acute myocardial infarction, congestive heart failure due to left ventricular dysfunction, arrhythmias, conduction disturbances or sudden death.

Angina pectoris is usually experienced by the patient as "chest discomfort", which is often located retrosternal, but frequently radiates into the neck or the ulnar aspect of the left or both arms. These attacks are generally provoked by a predictable amount of physical effort or emotional distress and are the result of an imbalance between myocardial oxygen demand and supply. Angina pectoris may occur as a result of a transient reduction of coronary blood flow caused by coronary vasoconstriction alone, or superimposed on a localized anatomical obstruction of a coronary artery due to an atherosclerotic plaque. The diagnosis of angina pectoris implies that there has been no myocardial damage and, consequently, no post-infarct scarring in the myocardium is to be expected (Gravanis, $1987)$

Acute myocardial infarction is caused by a sustained reduction in coronary blood flow below a critical level and is the result of irreversible cellular injury and necrosis of the hypo- or nonperfused myocardium. Myocardial infarcts are often classified into regional and subendocardial. Regional myocardial infarction occurs in the anatomic distribution of a coronary artery subtending a particular segment of the myocardium. 
The correlation between the site of major arterial obstruction and the geographic location of a regional infarct is fairly constant. For example, occlusion of the left anterior descending coronary artery leads to anteroseptal infarction of the left ventricle. A regional myocardial infarction is occasionally followed by diffuse subendocardia: extension of the infarct, especially in patients with generalized coronary artery disease.

An acute myocardial infarction eventually leads to the development of an area of scar tissue. The structural alterations that occur early after a myocardial infarction are primarily observed in animal experiments (ligation of the left coronary artery in healthy dogs). These early changes are possibly reversible, and complete restoration of the myocardial area at risk is expected if oxygen is reintroduced, approximately 20-40 minutes after ligation (Gravanis, 1987). One of the earliest findings in an infarct is interstitial edema, along with reactive hyperemia at the peripheral zone of the infarct. Concomitantly, intracellular edema of cardiomyocytes appears and disintegration of the sarcoplasma, including the contractile proteins, follows if the ischemic attack persists. At the same time, pycnosis of cardiomyocyte nuclei may occur. The peak of necrosis of myocardial fibers occurs around the fitth day. Myocardial necrosis evokes an inflammatory reaction. Polymorphonuclear leucocytes appear in the interstitium and are followed, some days later, by plasma cells, lymphocytes and macrophages. The number of mononuclear inflammatory cells increases up to the third week, and they then remain in the developing scar for several months, but in reduced numbers. Also, proliferation of fibroblasts commences by the fourth day. The number of fibroblasts in the interstitium of the infarct area increases up to the third week. 
Newly deposited collagen begins to appear after one week and the amount of collagen gradually increases. Proliferation of blood vessels in the infarct tissue starts around the fourth day, peaks between the 3rd and 6th week and persists for several months. The final result of this reparative process is that of an almost a-cellular scar. This eventually results in reduced compliance of the infarcted myocardial segment.

After a myocardial infarction, the left ventricle contains a segment that is noncontractile and less compliant, in comparison with the non-infarcted part of the ventricle. Depending on the size of the infarct, the left ventricular ejection fraction and cardiac output decrease. When the akinetic area approaches 20 to $25 \%$ of the myocardium, the heart can no longer maintain an adequate stroke volume (Pfeffer and Braunwald, 1990). Patients with small infarcts therefore remain without direct life threatening symptoms. However, large transmural infarctions may in particular severely reduce cardiac output and congestive heart failure will develop. The ensuing clinical syndrome is characterized by circulatory congestion, low exercise capacity (Poole-Wilson et al, 1988), poor prognosis and high mortality (Gravanis, 1987).

The clinical outcome and prognosis of congestive heart failure seems to be dependent also on the development of structural alterations of the heart in the noninfarcted part of the myocardium. These structural alterations are often referred to as "ventricular remodeling" and include ventricular dilatation, the development of cardiomyocyte hypertrophy (in parallel with an increase in DNA content of cardiomyacytes and biochemical alterations of cardiac heavy and light (iso-) myosin chains) and alterations in the myocardial interstitium, including a decreased 
capillary density and the development of diffuse interstitial fibrosis.

Similar structural alterations of the myocardium occur in hypertensive individuals and in experimental models of pressure overload and myocardial infarction through left coronary artery ligation. Far less is, however, known about the alterations in the non-infarcted part of the human myocardium after infarction.

\subsection{CARDIAC REMODELING AND MYOCARDIAL INFARCTION}

\subsubsection{Ventricular dillatation}

In our initial experiments we found (chapter 3) dilatation of the left ventricle, during a period from 1 to 5 weeks after induction of the infarction.

The ventricular dilatation is not only the result of stretching and thinning of the infarct scar but also of stretching of the non-infarcted myocardium, probably (at least partially) as a result of initial side-to-side slippage of cardiomyocytes (Olivetti et al, 1990). This process of ventricular enlargement can be influenced by three interdependent factors: infarct size, infarct healing and ventricular wall stress. Ventricular enlargement increases ventricular wall stress and seems to be highly correlated with a bad prognosis (Pfeffer and Braunwald, 1990).

\subsubsection{Cardiomyocyte hypertrophy}

In the human (Meerson, 1983) and rat heart (Anversa et al, 1985) cardiomyocyte hypertrophy after a myocardial infarction has been described. In our experiments, we observed transient signs of cardiomyocyte hypertrophy (chapter 3). Hypertrophy of cardiomyocytes in the right ventricle was sustained up to the 3rd week after infarct induction. 
In the left ventricle cardiomyocyte volume was transiently increased in the first two weeks after M. This contrasts with the findings of Anversa et all (1985), who demonstrated a sustained cardiomyocyte hypertrophy up to 1 month after infarct induction in adult rats. The transient nature of the increased cardiomyocyte volume in the left ventricle could be explained by inter- and intracellular edema which is a transient phenomenon and only apparent early after MI. This suggests that hypertrophic stimuli for cardiomyocytes in the young adult Wistar rat in our experiments, are rather limited.

Additionally, a shift in (iso-) myosin composition of cardiomyocytes has been described. These changes have been studied in depth in the left ventricle in the rat heart. In response to volume overload, preferential synthesis of the V3 (B) heavy myosin chain (with a low ATPase activity and a slow shortening velocity) has been observed. The V3 myosins replace the $V_{1}(a)$ heavy myosin chains (with a high myosin ATPase activity and a rapid shortening velocity). Although this phenomenon has a negative inotropic effect, it improves mechanical efficiency and so saves on oxygen consumption and energy requirements (Katz, 1990). The changes in (iso-) myosin composition described in the rat ventricle, have also been observed in human atria, in which a decrease in the proportion of fast $(\alpha)$ atrial myosin heavy chains parallels the pathologic elevation of left atrial pressure and the extent of left atrial enlargement (Katz, 1990).

\subsubsection{Myocardial DNA synthesis}

Along with the hypertrophic response in human hearts also an increase of DNA content, with polyploidization of cardiomyocyte nuclei, has been observed (Vliegen 
et al 1987; Goodman et al "1990; Rubin and Fishbein, 1990) DNA synthesis of atrial cardiomyocytes in rat hearts has been shown to occur after electrical injury (Rumyantsev and Mirakyan, 1976). In addition, in the hypertrophic rat heart, instead of polyploidization of cardiomyocyte nuclei binucleation of cardiomyocytes has been demonstrated (Clubb and Bishop, 1984).

Also an increase in DNA synthesis of interstitial myocardial cells in the pressure overloaded rat heart has been observed (Morkin and Ashford, 1968). This suggests that myocardial remodeling also includes interstitial cell proliferation. Our experiments showed that interstitial myocardial fibroblast proliferation occurs as early as 4-7 days after induction of the infarction. This phenomenon has not been documented yet in human hypertrophic hearts and its functional consequenses in the rat heart are not clear. We cannot exclude that in the proliferative reaction in the interstitium endothelial cells participate but the reduction in myocardial capillary density subsequent to an acute infarction (Anversa et $a{ }^{n} 1986$ ) argues against this possibility.

\subsubsection{Myocardial interstitial collagen synthesis}

In experimental models of pressure overload and myocardial infarction in the rat, alterations in the composition of interstitial myocardial collagen content have been described (Weber et al, 1987, 1989). These include an initial increase in the production of type I collagen. Our experiments showed that an increase in interstitial myocardial collagen synthesis almost parallels the increase in interstitial DNA synthesis and also occurs as early as 4-7 days after induction of the infarction. 
Furthermore, the increase in myocardial collagen content is sustained until 5 weeks after induction of the infarction. These data corroborate with those of Michel et al (1988), who documented remodeling of the collagen matrix (of the non-infarcted myocardium) after a myocardial infarction. Excessive collagen production, with a preponderance of type I collagen has also been found in human transplanted hearts (Bishop et al, 1990). If and when these phenomena take place also in the non-infarcted part of the human myocardium after a myocardial infarction, is not known in detail. Remodeling of the collagen matrix increases passive myocardial stiffness and may eventually contribute to further impairment of the cardiac function (Katz, 1990).

\subsubsection{Myocardial capillary density}

The changes in the myocardial capillary network have been studied extensively in experimental models of pressure overload and myocardial infarction in the rat. A relative decrease in capillary density might be responsible for an increase in the oxygen diffusion distance (Anversa et al, 1986), which may provoke the development of cardiomyocyte necrosis and interstitial fibrosis.

In summary, the structural alterations of the cardiomyocytes and of the myocardial interstitium early after a myocardial infarction, may be viewed as an initial physiologic response of the heart to the impaired cardiac function. Later on this compensatory remodeling response of the myocardium may be followed by de-adaptation. If this occurs, wall tension increases and this will attenuate cardiac function. Thus, although the remodeling response of the myocardium after an acute myocardial infarction may be an initially beneficial physiologic response, it might 
contribute to the development of congestive heart failure in the long run (Katz, 1990).

\subsection{CARDIAC REMODELING AFTER MYOCARDIAL INFARCTION AND}

\section{ANGIOTENSIN \|I}

\subsubsection{Introduction, drug treatment}

The morbidity and mortality of congestive heart failure are still severe. Therefore, the goals of drug treatment after an acute myocardial infarction are to prevent the development of congestive heart failure or reduce its symptoms and improve prognosis when this syndrome has already developed. Clinical studies with several types of drugs have been conducted in order to find treatment regimens, which improve exercise capacity and prognosis of patients suffering from congestive heart failure. Large scale studies in heart failure patients with the angiotensin I converting inhibitors enalapril (Consensus Trial, 1987) and in rats with enalapril (Sweet et al, 1987) and captopril (Pfeffer et al 1985a) have shown that chronic converting enzyme inhibitor therapy improves survival. Furthermore, captopril therapy attenuates ventricular dilatation in rats (Pfeffer et al, 1985b) and humans (Pfeffer et al "1988; Pfeffer and Braunwald, 1990) after MI. This suggests that inhibition of the renin-angiotensin system might also influence the cardiac remodeling process. Drugs interfering with cardiac remodeling might prevent de-adaptation of this process and in this way prevent the development of congestive heart failure. On the other hand, interference with the initial beneficial physiologic response (the cardiac remodeling process) after an acute myocardial infarction might lead to unwanted dangerous side effects, like myocardial atrophy and the development of 
ventricular dilatation, leading to further impairment of cardiac function. Thus, timing of the start of therapy might be important. Some reports in the literature advocate early treatment (Sharpe, 1989; Gay, 1990), and suggest that therapy should be started in the first week after an acute myocardial infarction. In order to reach a rational decision regarding this issue it is important to know what the effects of early and delayed treatment are on cardiac structure and function after a myocardial infarction, since structure and function are closely interrelated.

The possibilities for systematic studies of the effects of early and delayed converting enzyme inhibitor treatment on the structure of the human myocardium after an acute myocardial infarction " however, are limited.

We therefore studied the effects of ligation of the left coronary artery on the structure of the non-infarcted part of the myocardium of the rat heart. We determined the effects of early and delayed treatment with the angiotensin I converting enzyme inhibitor captopril on the structural alterations of the non-infarcted part of the myocardium after an infarction and the early effects of administration of a nonpeptide, specific angiotensin II receptor blocking agent (DuP 753). In our experiments we focused on ventricular dilatation, cardiomyocyte hypertrophy, myocardial DNA synthesis and myocardial interstitial collagen content.

Studying the effects of treatment with the angiotensin I converting enzyme inhibitor captopril and treatment with the angiotensin II receptor blocker DuP 753 on the process of cardiac remodeling in response to a myocardial infarction, offers a possibility to answer the question whether or not and if so, how angiotensin II is involved in this myocardial response. Our studies can not discriminate between effects of the renin-angiotensin system or, alternatively, effects due to 
increased activity of the sympathetic nervous system, because these two systems are closely interrelated. Angiotensin II has a stimulating effect on the sympathetic nervous system and may as a result increase sympathetic nerve activity. The involvement of sympathetic nerve activity also seems plausible because in vitro experiments have shown that in addition to angiotensin $\|$ adrenergic receptors mediate hypertrophy of cardiomyocytes.

If angiotensin II mediates or modulates the remodeling response it can either be the result of activation of a local (cardiac) or of the systemic renin angiotensin system. With our experimental approach, discrimination between the effects of a local (cardiac) and a peripheral renin-angiotensin system is not possible.

\subsubsection{Ventricular dilatation and angiotensin II}

Our findings suggest that neither converting enzyme inhibition with captopril nor DuP 753 or hydralazine treatment, affect left ventricular dilatation after a myocardial infarction. These data seem to conflict with those of Pfeffer et al (1985b), who found a reduction of left ventricular dilatation in the infarcted rat heart after converting enzyme inhibition with captopril. However, in their study, treatment was started in the 3 rd week after infarct induction and was sustained during 1 year. Together with our observations, this might indicate that only long term (and not short term) inhibition of the formation of angiotensin II after a myocardial infarction leads to reduction of left ventricular dilatation. 


\subsubsection{Cardiomyocyte hypertrophy and angiotensin II}

Early converting enzyme inhibition with captopril reduced the left ventricular cardiomyocyte volume to sham levels, while treatment with the arteriolar vasodilator hydralazine did not affect this parameter (chapter 4). Therefore it is unlikely that the observed reduction in cardiomyocyte volume is mediated by blood pressure and/or afterload reduction, since both drugs reduced the blood pressure to a similar extent.

If angiotensin II has a direct effect on cardiomyocyte hypertrophy this should be mediated by specific All receptors on the sarcolemmal membrane and/or in the nucleus of the cardiomyocyte. In binding studies, 2 types of binding sites for All have been identified. They have been designated All-1 and All-2 sites (Wong et al, 1990). It has recently been demonstrated that approximately half of the All bindling sites in the rabbit heart are of the All-1 type, while the other half consists of the All2 type (Rogg et al, 1990). In contrast to the All-1 binding site, the All-2 site has not been shown as yet to be linked to any known functional second messenger system. We found that blocking the All-1 receptor With DuP 753 decreases the left ventricular cardiomyocyte volume to some extent (chapter 6). However, when compared to captopril treated animals, this parameter still showed a sustained increase. This finding indicates that if cardiomyocyte hypertrophy in vivo is induced by angiotensin II this is only to a limited extent mediated by the All-1 binding site. At this stage a possible role for the All-2 site as one of the mediators in cardiac remodeling after a myocardial infarction cannot be excluded. Alternatively, the effect of angiotensin II may depend upon interaction with a receptor to which the All-1 site blocking agent (DuP 753) does not have access. 
In this regard, an angiotensin II binding site on the nuclear chromatin is a candidate site too (Dzau, 1987; Re, 1987). It is also possible that the captopril effect is not mediated by angiotensin II. Since the converting enzyme also inhibits the breakdown of bradykinin, a possible mediating role for this agent in cardiomyocyte hypertrophy can not be excluded.

Delayed treatment with both captopril and hydralazine reduced cardiomyocyte volume to the same extent (chapter 4). This finding indicates that increased wall tension is the main cause of late cardiomyocyte hypertrophy.

\subsubsection{Myocardial fibroblast proliferation and anglotensin II}

Our experiments (chapter 5) show that fibroblast proliferation occurs in the left and in the right ventricular myocardium in the first 2 weeks after MI. Although some investigators have reported on interstitial remodeling in human myocardial disease (Bishop, 1990), these phenomena have not been extensively and systematically studied in an experimental model of myocardial infarction. Our findings indicate that fibroblast proliferation depends on angiotensin II, since early captopril treatment reduced DNA synthesis, while this parameter was not affected by lowering the blood pressure with hydralazine. This is in line with the findings of Schelling et al ( 1979), who demonstrated that angiotensin II in vitro stimulates proliferation of 3T3fibroblasts. The latter finding also indicates that fibroblasts bear angiotensin II receptors, since the effect could be inhibited by the angiotensin II antagonist saralasin. A direct angiotensin II effect is also supported by our data on blocking of the angiotensin $11-1$ receptor with DuP 753 , in that this agent (partially) reduces interstitial DNA synthesis. 
The fact that the reduction is only partial leaves a potential role for the angiotensin II-2 receptor in myocardial fibroblast proliferation after an infarction. The existence of the angiotensin II receptors in myocardial interstitial fibroblasts as well as their precise function in these cells remain a topic of further studies.

\subsubsection{Myocardial interstitial collagen synthesis and angiotensin II}

Our experiments (chapters 5 and 6 ) show that early treatment with captopril, DuP 753 and hydralazine reduces the collagen content of the non-infarcted part of the

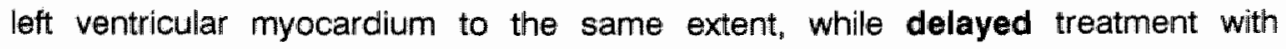
captopril or hydralazine does not influence the interstitial collagen content at all. This findings indicate that the early increase in the myocardial collagen content after a myocardial infarction is the result of several different stimuli. These might include activation of the renin-angiotensin system, increased wall tension, increased bradykinin levels and an activated sympathetic nervous system. The latter mechanism has been extensivelly studied by Pick et al (1989) in a model of pressure overload. Adrenergic receptors, however, have not been demonstrated in fibroblasts. Furthermore, our observations suggest that myocardial DNA synthesis early after a myocardial infarction is regulated independent from myocardial collagen synthesis, since early captopril and hydralazine treatment both reduced the collagen content, while DNA synthesis was only reduced by captopril. This is also supported by recent observations in our laboratory (Cleutjens, personal communication), which indicate that collagen type I mRNA is predominantly expressed in cells which do not synthesize DNA following MI. The discrepancy between DNA-synthesis and collagen-synthesis suggests, that in the acute phase 
of myocardial infarction collagen-synthesis is restricted to resident fibroblasts. The off-spring of these cells may, after maturation, contribute to collagen synthesis.

Our data on the effects of delayed treatment with captopril or hydralazine, indicate that once collagen deposition has taken place, the myocardial collagen content can no longer be reduced by a 2 week period of converting enzyme inhibition or afterload reduction, started in the 4th week after infarct induction.

\subsection{FUTURE PROSPECTS}

In summary, our most important conclusions are that almost immediately after an acute myocardial infarction, activation of the renin-angiotensin system leads to limited cardiomyocyte hypertrophy. In parallel, increased ventricular wall tension stimulates resident interstitial fibroblasts to produce collagen type I. At the same time angiotensin II induces fibroblast proliferation. Later on, the collagen synthesizing activities of the newly formed fibroblasts also contribute to the increased myocardial collagen content. The latter phenomena might add to preservation of the already impaired cardiac function, early after a myocardial infarction.

Thus, the interstitial compartment of the myocardium appears to play an important role in the cardiac remodeling process early and late after a myocardial infarction. This points towards the necessity to direct further research to the myocardial interstitium, rather than developing further variations on the theme of the contractile apparatus (cardiomyocytes) of the heart.

Although our results clearly indicate that the renin-angiotensin system plays a role in cardiac remodeling after myocardial infarction, the precise mechanism remains unclear. 
Therefore studies are necessary to elucidate how the components of the local cardiac renin-angiotensin system are involved in cardiac remodeling after Ml. Our findings also point towards but do not clearly elucidate the role of the sympathetic nervous system and bradykinin in cardiac remodeling. Additional studies should be conducted to determine the possible involvement of these regulating components in the development of structural alterations of cardiomyocytes and of the myocardial interstitium after MI.

Furthermore, Schoemaker et al (1991), reported that inhibition of the angiotensin | converting enzyme early after $\mathrm{Ml}$ does not augment, but rather attenuates cardiac fuction in rats. Our findings regarding the early (physiological) structural alterations of the myocardium after an infarction and the effects of captopril thereon, provide a theoretical basis for the observation of Schoemaker et al (1991) and stress rational timing of treatment.

Data from animal models cannot be directly extrapolated to the (far more complex) human situation and therefore our experiments need to be completed with studies of the effects of similar treatment regimens in man. 


\section{REFERENCES}

Anversa, P., Loud, A.V., Levicky, V., Guideri, G. Left ventricular failure induced by myocardial infarction. I. Myocyte hypertrophy. Am J Physiol 248, H876-882 (1985).

Anversa, P., Beghi, C. Kikkawa, Y., Olivetti, G. Myocardial infarction in rats. Infarct size, myocyte hypertrophy, and capillary growth. Circ Res 58, 26-37 (1986).

Bishop, J.E., Greenbaum, R., Gibson, D.G., Yacoub, M., Laurent, G. Enhanced deposition of predominantly type $\mid$ collagen in myocardial disease. J Moll Cell Cardiol 22, 1157-1165 (1990).

Clubb, F.J., Bishop, S.P. Formation of binucleated myocardial cells in the neonatal rat. An index for growth hypertrophy. Lab Invest 50, $571-577$ (1984).

Consensus Trial Study Group. Effects of enalapril on mortality in severe congestive heart failure. Results of the cooperative North Scandinavian enalapril survival study (Consensus). N Eng J Med 316, 1429-1435 (1987).

Dzau, V.J. Implications of local angiotensin production in cardiovascular physiology and pharmacology. Am J Cardiol 59, 59A-65A (1987).

Gay, R.G. Early and late effects of captopril treatment after large myocardial infarctions in rats. J Am Coll Cardiol 16, 967-977 (1990).

Goodman, L.C., Kelly, S., Fishbein, M.C., Epling, S, Lee, S. DNA flow cytometry of myocardial cell nuclei in paraffin-embedded, human autopsy, cardiac tissue. Am $J$ Cardiovasc Pathol 3,55-59 (1990).

Gravanis, M.B. Cardiovascular pathophysiology (eds.: Day, W. Ramos-Englis, M.) McGraw-Hill Inc., USA (1987).

Katz, A.M. Cardiomyopathy of overload. New Eng J Med 3(2), 100-110 (1990).

Meerson, F.Z. The failing heart: adaptation and de-adaptation (ed: Katz, A.M.). Raven Press, New York (1983).

Michel, J-B., Lattion, A-L., Salzmann J-L., de Lourdes Cerol, M., Philippe, M., Camelleri, J-P., Corvol, $P$. Hormonal and cardiac effects of converting enzyme inhibition in rat myocardial infarction. Circ Res 62, 641-650 (1988).

Morkin, E., Ashford, T.P. Myocardial DNA synthesis in experimental cardiac hypertrophy. Am J Physiol 215, 1409-1413 (1968).

Olivetti, G., Capasso, J.M., Sonnenblick, E.H., Anversa, P. Side-to-side slippage of myocytes participates in ventricular wall remodeling acutely after myocardial infarction in rats. Circ Res 76, 23-34 (1990). 
Pfeffer, M.A., Pfeffer, J.M., Steinberg, C., Finn, P. Survival after an experimental myocardial infarction: benficial effects of long-term therapy with captopril. Circulation $72 ; 406-412$ (1985a).

Pfeffer, J.M., Pfeffer, M.A., Braunwald, E. Influence of chronic captopril therapy on the infarcted left ventricle of the rat. Circ Res $57,84-95$ (1985b).

Pfeffer, M.A. Lamas, G.A., Vaughan, D.E., Parisi, A.F., Braunwald, E. Effect of captopril on progressive ventricular dilatation after anterior myocardial infarction. New Eng J med 319, 80-86 (1988).

Pfeffer, M.A., Braunwald, E. Ventricular remodeling after myocardial infarction. Experimental observations and clinical observations. Circulation 81, 1161-1172 (1990).

Pick, R., Jalil, J.E., Janicki, J.S., Weber, K.T. The fibrillar nature and structure of isoproterenol-induced myocardial fibrosis in the rat. Am J Pathol 134, 365-371 (1989).

Poole-Wilson, P.A, Buller, N.P., Lipkin, D.P. Regional blood flow, muscle strength and skeletal muscle histology in severe congestive heart failure. Am J Cardiol 62, $49 \mathrm{E}-52 \mathrm{E}(1988)$.

Rogg, H., Schmid, A., de Gasparo, M. Identification and characterization of angiotensin II receptor subtypes in rabbit ventricular myocardium. Biochem Biophys Res Communn, in press (1991).

Rubin, S.A., Fishbein, M.C. Effect of chemical sympathectomy on cardiac hypertrophy and haemodynamics following myocardial infarction in the rat. Am J Cardiovasc Patholl 3, 45-53 (1990).

Rumyantsev .P.P. Mirakyan. V.O. Increased activity of DNA synthesis and mitosis in rat atrial muscle cells under ventricular myocard infarction and local injuries of auricles. Vir Arch Cell Pathol 20, 329-342 (1976).

Schelling, P., Ganten, D. Speck, G., Fischer, H. Effects of angiotensin II and angiotensin II antagonist salarasin on cell growth and renin in 3T3 and SV3T3 cells. J Cell Physiol 98, 503-514 (1979).

Schoemaker, R.G., Debets, J.J.M., Struyker-Boudier, H.A.J., Smits, J.F.M. Delayed but not immediate therapy improves cardiac function in conscious rats, following myocardial infarction. J Moll Cell Cardial. In press. (1991).

Sharpe, D.N. Angiotensin converting enzyme inhibitors in heart failure: a case for earlier intervention? ACE Rep 59, 1-6 (1989). 
Sweet, C.S., Emmert, S.E., Stabilito, I.I., Ribeiro, L.G.T. Increased survival in rats with congestive heart failure treated with enalapril. J Cardiovasc Pharmacol 10, 636$642(1987)$.

Vliegen, H.W. Myocardial changes in ventricular hypertrophy. A morphometric, flow cytometric and biochemical study. PhD Thesis, Leiden, The Netherlands (1987).

Weber, K.T., Janicki, J.S., Pick, R., Abrahams, C, Shroff, S.G.Bashey, R.I., Chen, R.M. Collagen in the hypertrophied, pressure overloaded myocardium. Circulation 75(supp| II), II-40-\|1-47 (1987).

Weber, K.T., Pick, R., Jalil, J.E., Janicki, J.S., Carroll, E.P. Patterns of myocardial fibrosis. J Mol Cell Cardial 21 (suppl V), 121-131 (1989).

Wong, P.C., Price, W.A., Chiu, A.T., Duncia, J.V., Carini, D.J., Wexler, R.R., Johnson, A.L., Timmermans, P.B.M.W.M. Nonpeptide angiotensin II receptor antagonists. VIII. Characterisation of functional antagonism displayed by DuP 753 , an orally active antihypertensive agent. J Pharmacol Exp Ther 252, 719-725 (1990). 


\section{SUMMARY}

In the last two decennia, ischemic heart disease has become the prime cause of death in the civilized world. The term "ischemic heart disease" refers to clinical manifestations of coronary atherosclerosis. The ensuing myocardial hypoperfusion may present as angina pectoris, acute myocardial infarction, congestive heart failure due to ventricular dysfunction or sudden death.

An acute and large myocardial infarction is followed by structural alterations not only in the infarcted, but also in the non-infarcted part of the heart. These structural alterations are referred to as "cardiac remodeling" and include ventricular dilatation. cardiomyocyte hypertrophy, biochemical alterations of cardiac myosins and structural alterations of the myocardial interstitium. Although this initial response of the heart to a myocardial infarction should be regarded as a physiologic response to maintain cardiac function, it can be followed by de-adaptation, which becomes manifest in the development of congestive heart failure. In patients with this syndrome the exercise capacity is low and the mortality is high.

Large scale clinical and experimental animal studies have shown that after a myocardial infarction inhibition of the renin-angiotensin system with angiotensin I converting enzyme inhibitors such as enalapril and captopril improves exercise capacity and reduces mortality. However, the effects of these drugs on the structural changes in the non-infarcted part of the myocardium after a myocardial infarction in this process of cardiac remodeling are not yet known in detail.

Although angiotensin $\|$, which is elaborated by an activated renin-angiotensin system, seems to play an important role in cardiac remodeling after an acute 
myocardial infarction, the exact mechanism has not been elucidated. Furthermore, the effects of treatment with angiotensin I converting enzyme inhibitors on these structural alterations have not been extensively documented. Although this type of treatment appears to be beneficial, it is possible that early treatment interferes with the physiological remodeling response. If that would be the case, treatment would not have to be started early but delayed after an acute myocardial infarction, to prevent possible adverse side effects. Conceivably, the timing of therapy could be important.

The possibilities for systematic studies of the effects of early and delayed converting enzyme inhibitor treatment on the structure of the human myocardium after an acute myocardial infarction, however, are limited. Therefore we studied these effects in the rat model.

Initially we studied the effects in time of ligation of the left coronary artery on the structure of the non-infarcted part of the myocardium of the rat heart. We furthermore determined the effects of early and delayed treatment with the angiotensin I converting enzyme inhibitor captopril on the structural alterations of the noninfarcted part of the myocardium after an infarction. To elaborate further on the mechanism of the effects we observed, we subsequently studied the early effects of administration of a non-peptide, specific angiotensin II-1 receptor blocking agent (DuP 753). 
In our experiments we focussed on ventricular dilatation, cardiomyocyte hypertrophy, myocardial DNA synthesis and myocardial interstitial collagen content.

In our initial experiments the development of the remodeling response without pharmacological intervention was studied. We found dilatation of the left ventricle, during a period from 1 to 5 weeks after induction of the infarction (chapter 3) During this period, we also observed transient signs of cardiomyocyte hypertrophy. Hypertrophy of cardiomyocytes in the right ventricle was sustained up to the 3rd week after infarct induction. In the left ventricle cardiomyocyte volume was transiently increased in the first two weeks after MI. The transient nature of the increased cardiomyocyte volume in the left ventricle might be the result of interand intracellular edema which is a transient phenomenon and only apparent early after MI. This aspect was not addressed directly in our experiments. These data suggest that hypertrophic stimuli for cardiomyocytes in the young adult Wistar rat in our experiments, are rather limited. Our experiments also showed that fibroblast proliferation and an increase in interstitial myocardial collagen synthesis occur as early as 4-7 days after induction of the infarction. We cannot exclude that in the proliferative reaction in the interstitium endothelial cells participate but the reduction in myocardial capillary density subsequent to an acute infarction argues against this possibility.

Studying the effects of treatment with the angiotensin I converting enzyme inhibitor captopril and treatment with the angiotensin II-1 receptor blocker DuP 753 on the process of cardiac remodeling in response to a myocardial infarction, offers a possibility to answer the question whether or not and if so, 
how angiotensin $\|$ is irvolved in this myocardial response. A limitation of this approach, however, is that it is indirect and therefore such studies can not discriminate between direct effects of the renin-angiotensin system or, alternatively, indirect effects due to increased activity of the sympathetic nervous system.

\section{Cardiomyocyte hypertrophy and angiotensin II}

Early converting enzyme inhibition with captopril reduced the left ventricular cardiomyocyte volume to sham levels, while treatment with the arteriolar vasodillator hydralazine did not affect this parameter (chapter 4). Therefore it is unlikely that the observed reduction in cardiomyacyte volume is mediated by blood pressure and/or afterload reduction, since both drugs reduced the blood pressure to the same extent. We also found that blocking the All-1 receptor with DuP 753 decreases the left ventricular cardiomyocyte volume to some extent (chapter 6). In this situation a possible role for the All-2 receptor system as one of the mediators in cardiac remodeling after a myocardial infarction cannot be exclucled. Alternatively, the effect of angiotensin II may depend upon interaction with a receptor to which the All-1 receptor blocking agent (DuP 753 ) does not have access. In this regard, an angiotensin II binding site on nuclear chromatin seems to be relevant. It is also possible that the captopril effect is not mediated by angiotensin II. Since the converting enzyme also inhibits the breakdown of bradykinin, a possible mediating role for this agent in cardiomyocyte hypertrophy can not excluded.

Delayed treatment with both captopril and hydralazine reduced cardiomyocyte volume to the same extent (chapter 4). This finding indicates that increased afterload is the main cause of late cardiomyocyte hypertrophy. 


\section{Myocardial fibroblast proliferation and angiotensin II}

Our findings (chapter 5) indicate that fibroblast proliferation depends on angiotensin II, since early captopril treatment reduced DNA synthesis, while this parameter was not affected by lowering the blood pressure with hydralazine. This finding fits with the possibility that myocardial interstitial fibroblasts bear angiotensin II receptors. A direct angiotensin II effect is also supported by our data on blocking of the angiotensin 11-1 receptor with DuP 753 , in that this agent (partially) reduces interstitial DNA synthesis. The fact that the reduction is only partial leaves a potential role for the angiotensin $11-2$ receptor in myocardial fibroblast proliferation after an infarction. The existence of the angiotensin II receptors in myocardial interstitial fibroblasts as well as their precise function in these cells remain a topic for further studies.

\section{Myocardial interstitial collagen synthesis and angiotensin II}

Our experiments (chapters 5 and 6) show that early treatment with captopril, DuP 753 and hydralazine reduces the coliagen content of the non-infarcted part of the left ventricular myocardium to the same extent, while delayed treatment with captopril or hydralazine does not influence the interstitial collagen content at all. These findings indicate that the early increase in the myocardial collagen content after a myocardial infarction is the result of several different stimuli. These might include activation of the renin-angiotensin system, increased wall tension, increased bradykinin levels and an activated sympathetic nervous system.

Our data on the effects of late treatment with captopril, DuP 753 or hydralazine, indicate that once collagen deposition has taken place, the myocardial collagen 
content can no longer be reduced by converting enzyme inhibition. All-1 receptor blockade or afterload reduction.

From this thesis it can be concluded that almost immediately after an acute $M !$, the sympathetic nervous system activation in conjunction with renin-angiotensin system activation leads to early structural alterations of the myocardium after an infarction. Since these structural alterations constitute a physiological response to an acute myocardial infarction, rational development of pharmacotherapeutic regimens for the treatment of myocardial infarct patients, should take the effects on myocardial remodeling into account. 


\section{SAMENVATTING}

Ischaemische hartziekten vormen sinds enkele decennia de belangrijkste doodsoorzaak in de Westerse wereld. Deze hartziekten zijn voor een groot deel het gevolg van atherosclerotische veranderingen van de kransslagaders van het hart. Verminderde myocardiale doorbloeding is het gevolg. Deze kan zich uiten in angina pectoris, acuut myocardinfarct, hartfalen of acute dood.

$\mathrm{Na}$ een groot myocardinfarct in de linker hartkamer ontstaan structurele veranderingen van het geinfarceerde maar ook het niet-geinfarceerde myocard. Deze veranderingen worden in de angelsaksische wetenschappelijke literatuur ook wel "cardiac remodeling" genoemd. Na een myocardinfarct dilateert de linker hartkamer, ontstaat cardiomyocyt hypertrofie, treden biochemische veranderingen op in de myosines van de hartspiercellen en verandert de structuur van het myocardiale interstitium. Deze in beginsel fysiologische reactie van het myocard op een infarct is gericht op het handhaven van de cardiale functie, doch kan worden gevolgd door de-adaptatie. Dit uit zich in hartfalen, een klinisch goed omschreven syndroom met als belangrijkste kenmerken lage inspanningstolerantie en hoge mortaliteit. Zowel klinische als experimentele studies hebben aangetoond dat remming van het renine-angiotensine systeem met behulp van angiotensine I converting enzyme remmers (captopril en enalapril) na een myocardinfarct de inspanningstolerantie verhoogt en de mortaliteit verlaagt. 
De effecten van deze farmaca op de structurele veranderingen in het nietgeinfarceercle deel van het myocard na een infarct zijn echter niet tot in details bekend. Angiotensine $\|$, dat vrijkomt bij activatie van thet renine-angiotensine systeem, speelt een belangrijke rol bij structurele veranderingen van het nietgeinfarceerde myocard na een infarct. Het mechanisme waarlangs dit wordt geefectueerd is echter nog niet geheel opgehelderd. Hoewel behandeling met angiotensine I converting enzyme remmers na een infarct gunstige effecten lijkt te hebben, is de mogelijkheid niet uitgesloten dat deze farmaca in de vroege- of herstel fase van een myocardinfarct interfereren met de fysiologische reactie die weerspiegeld wordt in structuur veranderingen. Om ongewenste bijwerkingen te voorkomen lijkt bepalen van het juiste startpunt van behandeling belangrijk. Dit kan inhouden dat behandeling met deze farmaca niet in de vroege fase na een infarct mag plaatsvinden doch dient uitgesteld te worden tot na de herstelfase.

De mogelijkheden voor systematisch onderzoek naar de effecten van vroege en uitgestelde behandeling van angiotensine I converting enzyme remmers na een myocardinfarct bij de mens, zijn beperkt. Daarom bestudeerden wij deze effecten in een proefdier model bij de rat. Wij bestudeerden de ontwikkeling van de structurele veranderingen van het niet geinfarceerde myocard na ligatie van de linker coronair arterie. Tevens werd onderzoek gedaan naar de effecten van vroege en uitgestelde behandeling met de angiotensine I converting enzyme remmer captopril op deze structuur veranderingen. Om meer inzicht te krijgen in de mechanismen die ten grondslag liggen aan deze effecten werd de invloed bestudeerd van het blokkeren van de angiotensine II-1 receptor met een specifieke blokker (DuP 753). 
Als parameter voor structuur veranderingen bepaalden wij de binnen omtrek van de hartkamer, cardiomyocyt grootte, myocardiale DNA synthese en interstitieel collageen gehalte.

In ons eerste experiment bestudeerden wij de ontwikkeling van de structuur veranderingen na een myocardinfarct, zonder farmacologische interventie. Wij vonden dilatatie van de linker hartkamer gedurende de periode van 1 tot 5 weken na inductie van het myocard infarct (hoofdstuk 3). In deze periode was er ook sprake van voorbijgaande cardiomyocyt hypertrofie. Deze was in de rechter hartkamer aantoonbaar tot de derde week en in de linker hartkamer tot de tweede week na inductie van het infarct. De voorbijgaande toename van het volume van cardiomyocyten in de linker hartkamer is mogelijk het gevolg van het optreden van intracellulair oedeem vroeg na een myocardinfarct.

Dit aspect hebben wij in onze studies niet verder onderzocht. Onze gegevens suggereren dat slechts in beperkte mate sprake is van stimuli die cardiomyocyt hypertrofie bij de jang volwassen Wistar ratten, die wij voor onze experimenten gebruikten, induceert. Verder toonden wi] aan dat er sprake is van fibroblast proliferatie en een stijging van de collageen inhoud van het myocardiale interstitium in het niet-geinfarceerde deel van het myocard, 4-7 dagen na de inductie van een infarct. Het is niet uitgesloten dat ook endotheelcellen prolifereren in het myocardiale interstitium. De reductie in capillaire dichtheid, die gevonden is bij myocard hypertrofie, maakt dit echter minder aannemelijk.

Het bestuderen van de effecten van behandeling met de angiotensine I converting enzyme remmer captopril en de angiotensine II-1 receptor blokker DuP 753 maakt het mogelijk een antwoord te geven op de vraag of en zo ja, hoe, 
angiotensine II betrokken is bij de reactie van het myocard op een infarct. In ons onderzoek konden wij echter geen verschil maken tussen effecten van het renine angiotensine systeem en die van sympathicus activatie, daar deze twee systemen nauw met elkaar verweven zijn.

\section{Cardiomyocyt hypertrofie en angiotensine II}

Vroege behandeling met de converting enzyme remmer captopril reduceerde het volume van cardiomyocyten in de linker hartkamer tot het niveau van nietgeinfarceerde controle dieren.

Behandeling met de arteriolaire vasodilatator hydralazine had geen effect op het cardiomyocyt volume (hoofdstuk 4). Het is daarom onwaarschijnlijk dat de reductie van het cardiomyocyt volume tijdens captopril behandeling veroorzaakt is door afterload vermindering, temeer daar beide farmaca een vergelijkbaar effect hebben op de bloeddruk. Tevens bleek dat toediening van de angiotensine $11-1$ receptor blokker DuP 753 leidt tot een gedeeltelijke normalisering van het volume van linker hartkamer cardiomyocyten (hoofdstuk 6). Daarom kan niet uitgesioten worden dat de angiotensine II-2 receptor een mediërende rol speelt bij het proces van structuur veranderingen na een myocardinfarct. Een andere mogelijkheid is dat het effect van angiotensine II wordt gemediëerd door een angiotensine II receptor, waarvoor de angiotensine $11-1$ receptorblokker DuP 753 geen affiniteit heeft. Tenslotte is het niet uitgesloten dat het effect van captopril niet samenhangt met angiotensine II. Omdat het converting enzyme tevens de afbraak van bradykinine remt, is het denkbaar dat bradykinine bij het onstaan van cardiomyocyt hypertrofie een rol speelt. 
Uitgestelde behandeling met captopril en hydralazine resulteerde in een vergelijkbare reductie van het cardiomyocyt volume (hoofdstuk 4). Dit impliceert dat een stijgende afterload mogelijk een belangrijke oorzaak is van cardiomyocyt hypertrofie na de herstelfase van een infarct.

\section{Myocardiale fibroblast proliferatie en angiotensine II}

Onze gegevens (hoofdstuk 5) suggereren dat myocardiale fibroblast proliferatie in het niet-geinfarceerde myocard na een infarct, afhankelijk is van angiotensine 11. Vroege behandeling met captopril reduceerde de DNA synthese, terwill bloeddruk verlaging met hydralazine geen effect had. Deze waarneming suggereert tevens dat myocardiale fibroblasten voorzien zijn van angiotensine II receptoren. Een mitogeen effect van angiotensine $\|$ op fibroblasten wordt eveneens gesuggereerd door de effecten van de angiotensine II-1 receptor blokker DuP 753 op interstitiele DNA synthese na een infarct. Behandeling met Dup 753 na een infarct vermindert de interstitiele DNA synthese, doch niet tot het normale niveau. Dit laatste zou kunnen betekenen dat ook de angiotensine $\|-2$ receptor bindingsplaats bij fibroblast proliferatie na een infarct een mediërende rol speelt. Of angiotensine II receptoren bij myocardiale fibroblasten voorkomen en zo ja wat hun functionele betekenis is, is echter nog niet opgehelderd.

\section{Myocardiale interstitiele collageen synthese en angiotensine II}

Onze experimenten (hoofdstukken 5 en 6) tonen aan dat door vroege behandeling met captopril, DuP 753 en hydralazine de collageen inhoud van het nietgeinfarceerde myocard van de linker hartkamer na een infarct wordt verminderd. 
Uitgestelde behandeling met captopril en hydralazine had geen effect op de collageen inhoud. Onze gegevens suggereren dat de toename van het myocardiale collageen gehalte vroeg na een myocardinfarct het gevolg is van diverse stimuli, waaronder activatie van het renine angiotensine systeem, toename van de ventriculaire wandspanning door verhoging van de afterload, verhoogde bradykinine (plasma/weefsel) spiegels en sympathicus activatie. Het effect van uitgestelde behandeling met captopril en hydralazine suggereert dat een eenmaal toegenomen myocardiale collageen inhoud niet meer te reduceren is door converting enzyme remming of afterload reductie.

Op basis van de resultaten van de experimenten, beschreven in dit proefschrift, kan worden geconcludeerd dat activatie van het renine angiotensine systeem en het sympathische zenuwstelsel na een acuut myocardinfarct van de linker hartkamer bij de rat, leidt tot structurele veranderingen in het nietgeinfarceerde

myocard. Hoewel deze veranderingen zich deels voltrekken aan cardiomyocyten lijken de veranderingen van het myocardiale interstitium eveneens van grote betekenis, omdat zij de fysiologische reactie van het hart op een infarct weerspiegelen, die zou moeten leiden tot functie verbetering. De ontwikkeling van rationele farmacotherapeutische behandeling van myocardinfarct patiènten dient (mede) gebaseerd te zijn op deze waarnemingen. 


\section{CURRICULUM VITAE}

31 mei 1956

1968-1975

1975-1976

1976-1983

$1983-1985$

$1985-1990$

Februari 1991-
Geboren te Vlaardingen

Gymnasium B, Christelijke Scholengemeenschap

"Joh. Calvijn", Rotterdam

Propedeutisch examen Biologie, Rijksuniversiteit Utrecht

Studie Geneeskunde, Erasmus Universiteit, Rotterdam 1979, Research stage, Gelukspan Hospital, Bophuthatswana, Republic of South-Africa (Prof.dr. H.A. Valkenburg) 1979-1981, Student-assistent, Afdeling Pathologie, Acad.Ziekenhuis "Dijkzigt", Rotterdam ( $m w$ drs. D.H. Birkenhäger-Frenkel) 1982, Adjunct wetenschappelijk medewerker, Afdeling Pathologie, Acad. Ziekenhuis "Dijkzigt" Rotterdam (Prof.dr. R.O. van der Heul)

Militaire dienst, Res. Officier, arts-assistent, Afdeling Psychiatrie

Opleiding tot patholoog-anatoom, Afdeling Pathologie, Acad. Ziekenhuis Maastricht (Prof.dr. F.T. Bosman)

Staflid Afdeling Pathologie, Diagnostisch Centrum Stichting Samenwerkende Delftse Ziekenhuizen (SSDZ) 


\section{PUBLICATIONS}

\section{ABSTRACTS}

Cleutjens, J.P.M., Daemen, M.J.A.P., Van Krimpen, C., Smits, J.F.M., Bosman, F.T. Captopril reduces fibrosis of the non-infarcted myocardium after myocardial infarction. Am Heart Ass Meeting, Dallas, Texas, USA, in press (1990).

Cleutjens, J.P.M., Van Krimpen, C., Smits, J.F.M., Bosman, F.T., Daemen, M.J.A.P. Increase of type I and III collagen mRNA and protein in the infarcted and noninfarcted rat heart after myocardial infarction. International society for heart research, Leuven 1991, J Mol Cell Cardiol, in press (1991).

Van Krimpen, C., Schoemaker, R.G., Smits, J.F.M., Daemen, M.J.A.P., Bosman, F.T. Effects of captopril on the cellular response of the myocardium to infarction.

Pharmaceutisch Weekblad Scientific Edition 10,235 (1988).

Van Krimpen, C., Schoemaker, R.G., Smits, J.F.M., Daemen, M.J.A.P., Bosman, F.T. Effecten van captopril op de respons van het myocard na een infarct in de rat.

Ned Tijdsch Geneesk 133,2206 (1988).

Van Krimpen, C., Daemen, M.J.A.P., Schoemaker, R.G. Smits, J.F.M., Bosman, F.T. Effects of captopril on the response of the myocardium to infarction. FASEB $J$ 3(partl),A621 (abstr $\mathrm{nr}$ 2294) (1989).

Van Krimpen, C., Schoemaker, R.G., Daemen, M.J.A.P., Smits, J.F.M., Bosman, F.T. Cellular effects of angiotensin I converting enzyme inhibition after myocardial infarction in the rat. Proceed 30th Dutch Federation Meeting abstr nr 230 (1989).

Van Krimpen, C., Smits, J.F.M., Daemen, M.J.A.P., Bosman, F.T. Captopril reduces DNA synthesis in the rat heart after infarction. Pharmaceutisch Weekblad Scientific Edition 11,J12 (1989).

Van Krimpen, C., Smits, J.F.M., Debets, J.J.M., Daemen, M.J.A.P., Bosman, F.T. Captopril reduces the increase in DNA synthesis in the rat heart after myocardial infarction. FASEB $\downarrow 4$ (partl), A623 (abstr nr 2068) (1990).

Van Krimpen, C., Smits, J.F.M., Debets, J.J.M., Daemen, M.J.A.P., Bosman, F.T. Captopril reduceert de toename van DNA synthese in het myocard van de rat na een infarct. Ned Tijdsch Geneesk 134(37), 1823. (1990).

Van Krimpen, C., Cleutjens, J.P.M., Schoemaker, R.G., Smits, J.F.M., Daemen, M.J.A.P. Effects of early angiotensin II receptor blockade on structural alterations of the rat heart after infarction. (ACE congress, London, februari 1991, in press). 
Van Krimpen, C., Cleutjens, J.P.M., Schoemaker, R.G., Smits, J.F.M., Daemen, M.J.A.P. Effects of early angiotensin II receptor blockade on structural alterations of the rat heart after infarction. Proceedings of the 32nd Dutch Federation meeting (1991).

\section{FULL PAPERS}

Hoogland, H.J. Arends, J.W., Blijham, G.H., Braat, S.H.J.G. de Haan, J. van Krimpen, $C$. Death from chemotherapy in gestational trophoblastic disease. Europ J Obst \& Gyn Repr Biol 29,167-172 (1988).

Smits, J.F.M., Cleutjens, J.P.M., van Krimpen, C., Schoemaker, R.G., Daemen, M.J.A.P. Cardiac remodeling in hypertension and following myocardial infarction: effects of arteriolar vasodilators. Basic Res Cardiol 86(suppl 1), 133-139 (1991).

Smits, J.F.M., van Krimpen, C., Cleutjens, J.P.M., Schoemaker, R.G., Struyker Boudier, H.A.J., Bosman, F.T. Daemen, M.J.A.P.. Angiotensin II receptor blockade following myocardial infarction in rats; hemodynamic and structural effects. Submitted for publication.

Van Krimpen, C., Schoemaker, R.G., Cleutjens, J.P.M., Smits, J.F.M., StruykerBoudier, H.A.J., Bosman, F.T., Daemen, M.J.A.P. Angiotensin I converting enzyme inhibitors and cardiac remodeling. Basic Res Cardiol 86(suppl 1),149-155 (1991).

Van Krimpen, C., Smits, J.F.M., Cleutjens, J.P.M., Debets, J.J.M., Schoemaker, R.G., Struyker Boudier, H.A.J., Bosman, F.T., Daemen, M.A.J.P. DNA synthesis in the non-infarcted cardiac interstitium after left coronary artery ligation in the rat: effect of captopril. Submitted for publication.

Van Krimpen, C., Cleutjens, J.P.M., Schoemaker, R.G., Daemen, M.J.A.P., Smits, J.F.M. Structural and functional effects of early angiotensin II receptor blockade after myocardial infarction in the rat. Submitted for publication. 


\section{DANKWOORD}

"HERE, onze God, de majesteit en glorie van Uw naam vullen de gehele aarde en de hemelien wloeien er van over. Ais ik 's nachts omhoog kijk en het werk van Uw handen zie, de maan en de sterien, die U hun plaats gegeven hebt, dan kan ik maar niet begrijpen dat U zich bekommert om een klain en nietig mens. Dat $U$ werkelijk aandacht voor hem hebt! En $U$ hebi hem een plaats vlak onder Uzelf gegeven. U gaf hem een kroon wan giorie en eer. $U$ gaf hem zelfs macht over alles wat U heeft gemaakt; alles staat onder zijn gezag "Psalm 8).

Dit proefschrift was evenmin tot stand gekomen zonder de aandacht, mediewerking en intellectuele/praktische vaardigheden van de volgende mensen:

Dr. M.J.A.P. Daemen, beste Mat; ji bent niet alleen de man die me constant achter de vodden zat, maar ook vaak de inspirator en katalysator van de "wetenschappelijke arbeid" die resulteerde in deze dissertatie. Jouw kwalieiten staan bij mij hoog genoteerd, ik zal je dan ook niet gauw vergeten!

Dr. J.F.M. Smits, beste Jos; de "snelle" indruk die jij bij mil hebt achter gelaten is miet meer uit te wissen. Jouw pragmatische instelling en consciëntieuze begeleiding heeft mij nog al erens behoed voor het bewandelen van minder belangrijke zijpaden.

Prof. dr. F.T. Bosman, beste Fré; Ik heb veel van jou geleerd. Jouw heldere, kritische en geordende geest heeft (geholpen door het "rode potlood") met niet aflatende ijver bijgedragen tot het "componeren" vant een vloeiend en lezenswaardig verhaal met een duidelijke boodschap. lk hoop dal ook dit proetschrift daar een voorbeeld van is.

Prof. dr. H.A.J. Struyker Boudier, beste Harry; Jii hebt met een heldere en kritische evaluatie van mijn onderzoeksinspanningen en deze dissertatie, bijgedragen aan een vruchtbare samenwerking tussen die vakgraepen "pathologie" en "farmacologie".

Dr. R.G. Schoemaker, beste Regien; jouw onderzaeksbijdrage op het gebied vari de "haemodyna" mica" was complementair en scheppende voorwaarde voon het onderzoek beschreven in dit proefschrift.

Dr. Ir. J.P.M. Cleutjens, beste Jack; ik ben jou erkentelijk woor het dichten van cen aantal "experimentele gater", waarvan de resultaten verwerkt zijn in dit proeischritt.

Dr. M.G. Havenith, beste Miek, hartelijk bedankt woor jouw goede adwiezen, meedenken en doen op de werkvioer en daarbuiten.

J.J.M. Debets, beste Jack; jij hebt een zeer groot deel wan de proefdier operaties voor jouw rekening genomen. Jouw trefzekere en snelle handvaardigheid heeft mij vaak met ver- en bewondering wervuld.

Jan Smeets, Monique Vallinga, Monique Verluyten, Marie-Helene Lenders, Birgitte Kuipers en Helma van Essen ben ik veel dank verschuldigd woor hun adequate technische assistentio en/of adviezen.

De leden ven de beoordelingscommissie; Prof.dr M.A. Allessie, Dr. F.Bär, Prof.dr. F.C.S. Ramaekers, Prof.dr. J.J. Weening en Prof.dr. P.A. van Zwieten will ik bedanken voor de kritische evaluatie van het manuscript. Prof.dr. J.W. Arends (hoofol van de aldeling pathologia, Academisch Ziekenhuis Maastricht); beste Jan Willem, hartelijk dank voor louw corrigerende kanttekeningen wanneer tijdens mijn overgave aarn de "wetenschap" het gevaar dreigde van een sub-optimale aandacht voor de opleiding tot patholoog-anatoom.

Beste Adriaan, lieve Sophie, Just en Eline; Wij bewaren vele goede herinneringen aan de ons gegeven kameraadschap en gezeilige uren. Hartelijk dank?

Lieve Riena, ik heb veel tijd gebruikt, die elgemlijk voor ons besteme was. Zonder jouw geduld, begrip an goede zorgen, had ik deze kius nooit kunnen klaren. Mijn dank aan jou is niel goed in woorden uhl te drukken.

CvK juni 1991 